\title{
Knelpunten op de arbeidsmarkt en personeelsbeleid in de openbare apotheek
}

Citation for published version (APA):

de Grip, A., Sanders, J. M. A. F., \& Sieben, I. J. P. (2002). Knelpunten op de arbeidsmarkt en personeelsbeleid in de openbare apotheek. Researchcentrum voor Onderwijs en Arbeidsmarkt, Faculteit der Economische Wetenschappen. ROA Reports No. 11 https://doi.org/10.26481/umarep.2002011

Document status and date:

Published: 01/01/2002

DOI:

10.26481/umarep.2002011

Document Version:

Publisher's PDF, also known as Version of record

\section{Please check the document version of this publication:}

- A submitted manuscript is the version of the article upon submission and before peer-review. There can be important differences between the submitted version and the official published version of record.

People interested in the research are advised to contact the author for the final version of the publication, or visit the DOI to the publisher's website.

- The final author version and the galley proof are versions of the publication after peer review.

- The final published version features the final layout of the paper including the volume, issue and page numbers.

Link to publication

\footnotetext{
General rights rights.

- You may freely distribute the URL identifying the publication in the public portal. please follow below link for the End User Agreement:

www.umlib.nl/taverne-license

Take down policy

If you believe that this document breaches copyright please contact us at:

repository@maastrichtuniversity.nl

providing details and we will investigate your claim.
}

Copyright and moral rights for the publications made accessible in the public portal are retained by the authors and/or other copyright owners and it is a condition of accessing publications that users recognise and abide by the legal requirements associated with these

- Users may download and print one copy of any publication from the public portal for the purpose of private study or research.

- You may not further distribute the material or use it for any profit-making activity or commercial gain

If the publication is distributed under the terms of Article $25 \mathrm{fa}$ of the Dutch Copyright Act, indicated by the "Taverne" license above, 
Knelpunten op de arbeidsmarkt en personeelsbeleid in de openbare apotheek

ROA-R-2002/11

Andries de Grip

Jos Sanders

Inge Sieben

Researchcentrum voor Onderwijs en Arbeidsmarkt

Faculteit der Economische Wetenschappen en Bedrijfskunde Universiteit Maastricht

Maastricht, oktober 2002 
ISBN 90-5321-344-9

Sec02.099.doc 


\section{Inhoud}

Bladzijde

Voorwoord

Resumé

1 Inleiding 1

2 Actuele situatie en ontwikkelingen in de sector 5

2.1 De openbare apotheek 5

2.2 Veranderingen in de apothekersbranche 9

$\begin{array}{ll}2.3 \text { Personeel in de openbare apotheek } & 11\end{array}$

3 Knelpunten op de arbeidsmarkt $\quad 21$

$\begin{array}{ll}3.1 & \text { Inleiding } \\ 3.2 & 21\end{array}$

3.2 Vacatures in de openbare apotheek 22

3.3 Personeelsverloop in de openbare apotheek 26

3.4 Arbeidsmarktperspectieven van apothekersassistenten 31

3.5 Werkdruk van apothekersassistenten 32

4 HRM Beleid $\quad 35$

4.1 Werving en selectie $\quad 35$

4.2 Human Resources Development 46

4.3 Kwalitatieve en kwantitatieve inzetbaarheid 51

4.4 Arbeidsvoorwaardenbeleid 56

4.5 HRM beleid gericht op het onbenutte arbeidspotentieel 58

5 Effecten van HRM beleid $\quad 61$

$\begin{array}{ll}5.1 \text { Inleiding } & 61\end{array}$

5.2 HRM beleid en vacatures in de openbare apotheek 62

5.3 HRM beleid en personeelsverloop in de openbare apotheek 66

5.4 HRM beleid en werkdruk en ziekteverzuim in de openbare apotheek 67

5.5 HRM beleid en productiviteit in de openbare apotheek 70

$\begin{array}{lll}5.6 & \text { Enkele concluderende opmerkingen } & 72\end{array}$ 



\section{Voorwoord}

Dit onderzoek is een onderdeel van de arbeidsmarktmonitor voor de openbare apotheek, waarvan een beschrijving wordt gegeven in het Vooronderzoek arbeidsmarktmonitor apothekersbranche. Deze monitor wordt in opdracht van de Stichting Bedrijfsfonds Apotheken (SBA) uitgevoerd door het Researchcentrum voor Onderwijs en Arbeidsmarkt (ROA).

De arbeidsmarktmonitor bestaat uit een viertal deelonderzoeken waarin werkgevers (apothekers), werkende apothekersassistenten, schoolverlaters van de opleiding voor apothekersassistenten en gediplomeerde apothekersassistenten die voorheen in de openbare apotheek hebben gewerkt worden gemonitord. Als sluitstuk van de monitor zal bovendien een toekomstverkenning van de arbeidsmarkt voor apothekersassistenten plaatsvinden.

Dit rapport doet verslag van de resultaten van een in samenwerking met de Stichting Farmaceutische Kengetallen (SFK) opgezet enquête-onderzoek onder werkgevers (apothekers). Het onderzoek richt zich met name op de actuele personeelsproblematiek in de openbare apotheken in Nederland en de rol die het HRM (Human Resources Management) beleid van apothekers kan spelen bij het gemakkelijker kunnen aantrekken van nieuwe assistenten, het verminderen van het personeelsverloop, het verlagen van de werkdruk en het ziekteverzuim en het verhogen van de arbeidsproductiviteit.

Onze dank gaat uit naar de heer J. Sax van der Weijden (SBA), voor zijn rol bij de begeleiding van dit onderzoek. Ook zijn wij dank verschuldigd aan de heer J.L. Tinke (SFK) voor zijn waardevolle commentaar op een eerdere versie van de vragenlijst en deze eindrapportage. Ten slotte gaat onze dank uit naar de heer F. Baart (SFK), die verantwoordelijk was voor de verzameling en de cleaning van de gebruikte data. 



\section{Resumé}

In dit rapport wordt verslag gedaan van een door het Researchcentrum voor Onderwijs en Arbeidsmarkt (ROA) in opdracht van de Stichting Bedrijfsfonds Apotheken (SBA) en in samenwerking met de Stichting Farmaceutische Kengetallen (SFK) uitgevoerd onderzoek naar de knelpunten in de personeelsvoorziening en het personeelsbeleid in openbare apotheken. Dit onderzoek is een onderdeel van de Arbeidsmarktmonitor Apothekersbranche, die ROA uitvoert in opdracht van de SBA.

De apothekersbranche kampt mede als gevolg van de algehele krapte op de arbeidsmarkt voor middelbaar en hoger opgeleiden en de structurele stijging van het geneesmiddelengebruik met grote knelpunten in de personeelsvoorziening. Er is de apothekers in de openbare apotheek daarom veel aan gelegen om het personeelsverloop te beperken en de aantrekkingskracht van de branche te vergroten. Dit heeft geleid tot een toename van de aandacht voor 'human resource management' (HRM).

In dit rapport wordt inzicht gegeven in de mate waarin de apothekersbranche geconfronteerd wordt met knelpunten in de personeelsvoorziening. In aansluiting daarop wordt uitvoerig ingegaan op de verschillende facetten van het HRM. Tevens wordt zichtbaar gemaakt hoe elementen van het HRM beleid worden gebruikt om de knelpunten in de personeelsvoorziening aan te pakken.

\section{Hoofdstuk 2 Actuele situatie en ontwikkelingen in de sector}

De openbare apotheek

De meeste apotheken opereren zelfstandig. 35\% Van de apotheken behoort tot een apotheekgroep, waarvan de meerderheid tot een kleine apotheekgroep van maximaal 5 apotheken behoort. In dichtbevolkte gebieden (Randstad) is minder sprake van formele samenwerking dan in dunbevolkte gebieden (Noord Nederland).

\section{Personeel}

Van alle werknemers in de openbare apotheek is bijna $80 \%$ werkzaam als apothekersassistent. De gemiddelde leeftijd van de werknemers in de openbare apotheek ligt net iets onder de 37 jaar. In de regio's Noordwest en Middenwest zijn de apothekersassistenten gemiddeld het oudst.

De meerderheid van de werkzame apothekersassistenten is in dienst gekomen als schoolverlater. In de regio Oost zijn naar verhouding wat meer schoolverlaters werkzaam zijn dan in andere regio's en in de regio Zuidoost wat meer herintreders.

Assistenten verdienen per maand zo'n $€ 1.775,00$ bruto op basis van een fulltime baan. In kleine apotheken en in de regio Zuidoost ligt het brutomaandsalaris iets beneden dat gemiddelde. In de apotheken die deel uitmaken van een kleine apotheekgroep ligt het brutomaandsalaris wat hoger. Een verklaring voor dit verschil 
zou kunnen zijn dat de assistenten in de regio Zuidoost gemiddeld wat jonger zijn dan de assistenten in een aantal andere regio's.

\section{Veranderingen in de openbare apotheek}

De laatste jaren is er heel wat veranderd in het werk van de apothekersassistenten. Apothekers wijzen met name op de intensivering van de patiëntenvoorlichting en de toenemende mondigheid van cliënten. Dit leidt ertoe dat steeds meer een beroep wordt gedaan op de communicatieve vaardigheden van de apothekersassistent. Niet alleen in de alledaagse omgang met klanten in de zin van klantvriendelijkheid maar zeker ook vakinhoudelijk.

\section{Competenties van de apothekersassistenten}

Apothekers vinden over het algemeen dat ze zeer competente apothekersassistenten in dienst hebben. Apothekersassistenten scoren volgens de apothekers het hoogst op het recepteren van geneesmiddelen, het omgaan met collegae en zelfstandigheid. De assistenten scoren volgens de apothekers wat minder goed op hun vakinhoudelijke kennis. Daarbij gaat het zowel om kennis op het gebied van geneesmiddelen, als om kennis van ziektebeelden. De gemiddelde competentiescores in de zelfstandige apotheken liggen over het algemeen wat hoger dan de scores in apotheekgroepen. Vooral in apotheken die deel uitmaken van een apotheekgroep met meer dan 5 apotheken zijn de scores gemiddeld wat lager.

\section{Hoofdstuk 3 Knelpunten op de arbeidsmarkt}

\section{Vacatures}

Op het tijdstip van de enquête (november 2001) heeft 43\% van de apotheken één of meerdere vacatures openstaan. Voor de gehele branche komt dit neer op zo'n 850 openstaande vacatures op fulltime basis. Het overgrote deel hiervan zijn vacatures voor de functie van apothekersassistent. Vacatures voor een tweede apotheker komen minder vaak voor. Gezien het veel geringere aantal tweede apothekers dat werkzaam is in de openbare apotheek moet niettemin worden geconcludeerd dat ook voor deze groep de knelpunten aanzienlijk zijn. Omdat het aantal studenten farmacie bovendien terugloopt is de verwachting dat dit tekort nog zal toenemen. Met name in de Randstad zijn de problemen groot. Apothekers in de regio Noord daarentegen kennen de minste knelpunten in de personeelsvoorziening.

De openstaande vacatures zijn in $40 \%$ van de gevallen binnen 3 maanden vervuld. Toch moeten de meeste vacatures volgens de gangbare maatstaven als moeilijk vervulbaar getypeerd worden. Zo staat één op de vijf vacatures voor apothekersassistenten 3 tot 6 maanden open, en eenzelfde aantal 6 tot 12 maanden. Voor $16 \%$ van de vacatures duurt het zelfs meer dan een jaar voordat er een nieuwe assistent aangenomen wordt. De belangrijkste reden voor het moeilijk opvullen van vacatures is volgens de apothekers het te geringe aanbod van personeel. 
Het merendeel van de vacatures voor apothekersassistenten ontstaat vanuit de vervangingsvraag. Het gaat dan om het opvullen van plaatsen die vrijkomen doordat assistenten vertrokken zijn, minder zijn gaan werken, of tijdelijk niet inzetbaar zijn door ziekte of zwangerschapsverlof. Een toename in de hoeveelheid werk ligt veel minder vaak ten grondslag aan het ontstaan van vacatures.

\section{Personeelsverloop}

In de periode november 2000 tot november 2001 had $63 \%$ van de apotheken te maken met personeelsverloop. Zorgwekkend is de toestand in de Randstad. Hier is sprake van een hoog personeelsverloop, met name in de regio Noordwest. De instroom van nieuwe assistenten blijft ver achter bij de uitstroom, waardoor apothekers in de Randstad er vaak niet in slagen al hun vacatures op te vullen.

Al met al kan de uitstroom van apothekersassistenten aanzienlijk genoemd worden. Als belangrijkste redenen voor deze uitstroom worden door de apothekers de te lange reistijd en verhuizing van de assistent genoemd. Dit duidt erop dat apothekersassistenten graag dichtbij hun werk willen wonen. Daarnaast speelt de werksfeer en het niet bevredigend zijn van het soort werk een belangrijke rol bij het vertrek van apothekersassistenten, gevolgd door de betere carrièreperspectieven elders binnen of buiten de branche. Ook de te hoge werkdruk vormt volgens de apothekers een belangrijke uitstroomreden, met name in de regio's Noord en Noordwest.

Overigens denkt één op de vier apothekers dat het personeelsverloop de komende twee jaar verder zal toenemen. Met name in de regio Zuidoost verwachten veel apothekers een toename. Als belangrijkste redenen voor de toename geven de apothekers aan dat meer apothekersassistenten voor zorgtaken zullen kiezen, in deeltijd zullen gaan werken of met pensioen zullen gaan. Ook de hoge werkdruk onder assistenten zal, volgens de apothekers, voor een hoger personeelsverloop in de toekomst gaan zorgen.

\section{Hoofdstuk 4 HRM beleid}

De veranderingen in de apothekersbranche en de toename van de knelpunten in de personeelsvoorziening vragen om een goed doordacht HRM beleid dat gericht moet zijn op het op peil houden van de aanwezige kennis en vaardigheden binnen de branche en het uitbreiden van het beschikbare 'menselijke kapitaal' door middel van een goed doordachte arbeidsmarktstrategie. Deze elementen komen samen in wat algemeen bekend staat als het Human Resource Management (HRM): personeelsbeleid gericht op het optimaliseren van de inzet van medewerkers.

We onderscheiden vier facetten van het HRM beleid binnen de apothekersbranche.

- Werving en selectie;

- Human Resource Development in de vorm van training en ontwikkeling;

- Kwalitatieve en kwantitatieve inzetbaarheid;

- Arbeidsvoorwaardenbeleid. 


\section{Werving en selectie}

Ondanks hun problemen met het invullen van vacatures treft één op de tien apothekers géén extra maatregelen om vacatures vervuld te krijgen. In de regio Zuidoost is dat zelfs $18 \%$, terwijl juist in die regio veel apothekers verwachten dat de problemen met de werving van apothekersassistenten de komende twee jaar zullen toenemen.

Apothekers die problemen hebben met het invullen van vacatures voor apothekersassistenten gaan er in veel gevallen toe over anders opgeleiden aan te trekken. Het gaat vooral om apotheekhulpen, die ondersteunende taken van apothekersassistenten overnemen. Farmaceutische taken van assistenten kunnen en mogen zij niet uitvoeren. Voor het uitoefenen van het beroep apothekersassistent moet men in het bezit van het betreffende diploma zijn. Dat diploma geeft ook recht op het voeren van de titel.

Apothekers hebben bij de werving van nieuwe assistenten de voorkeur voor gediplomeerde schoolverlaters en assistenten uit een andere apotheek boven herintreders. De vroegere werkervaring van herintreders weegt kennelijk voor de apothekers niet op tegen actuele kennis en vaardigheden. In de regio Noordwest en Middenwest, de regio's met de meeste vacatures, is de voorkeur voor schoolverlaters wel minder eenduidig dan in de andere regio's. Dit kan er op duiden dat apothekers als gevolg van knelpunten in de personeelsvoorziening hun wervingsstrategie aanpassen.

In drie van de vier apotheken werkt tenminste één stagiaire van de Beroepsopleidende Leerweg (BOL). Vooral de wat grotere apotheken hebben BOL stagiaires in dienst. Ook zouden de knelpunten in de regio Noordwest ertoe kunnen leiden dat apothekers stagiaires beter belonen om hen in huis te halen en te houden. De helft van de apotheken heeft één of meerdere leerlingen van de Beroepsbegeleidende Leerweg $(\mathrm{BBL})$ in dienst. Slechts $60 \%$ van de apothekers die een vergoeding geven aan BBL'ers, doet dat in de vorm van het minimumloon. Apothekers in de regio Noord betalen BBL'ers minder dan apothekers in de regio Zuidoost.

\section{Human Resources Development}

In de apothekersbranche wordt volgens apothekers met name veel aandacht besteed aan vaktechnische cursussen (geneesmiddelenkennis en kennis van ziektebeelden). Meestal nemen apothekers en assistenten samen het initiatief voor een cursus. Opvallend is wel dat het initiatief voor het volgen van vakinhoudelijke cursussen vaak bij de assistent ligt en niet zozeer bij de apotheker. De cursussen op meer algemene vaardigheden worden daarentegen vaker door de apotheker geïnitieerd dan door de assistenten.

Vaktechnische cursussen worden volgens de apothekers relatief vaak in eigen tijd gevolgd, terwijl meer algemene cursussen vaak in werktijd worden gevolgd. In apotheken die deel uitmaken van een grote apotheekgroep (van 5 of meer apotheken) worden vakinhoudelijke cursussen veel vaker in werktijd gevolgd dan dat dat in 
zelfstandige apotheken of apotheken die deel uitmaken van een kleine apotheekgroep het geval is.

\section{Kwalitatieve en kwantitatieve inzetbaarheid}

Apothekers zetten apothekersassistenten ook in op taken die van origine niet tot hun takenpakket behoren. Hierbij gaat het vooral om managementtaken. In $6 \%$ van de apotheken nemen assistenten zowel farmaceutische taken, managementtaken als taken van lagere functies over.

In ongeveer driekwart van de apotheken werken assistenten wel eens over. In verreweg de meeste gevallen is dat overwerk volgens de apotheker echter niet structureel. Nagenoeg elke apotheker schuift ten slotte wel eens met de werktijden van het personeel om bezettingsproblemen op te lossen. Ook hier is echter geen sprake van een structureel verschijnsel. Waar knelpunten zijn in de vacature vervulling wordt wel wat meer met de werktijden van het personeel geschoven. Het percentage apotheken dat structureel met het personeel schuift is het hoogst in de drie regio's met de hoogste vacaturegraad; Noordwest, Middenwest en Zuidoost.

\section{Arbeidsvoorwaardenbeleid}

In de apothekersbranche bestaat veel aandacht voor 'klassieke' secundaire arbeidsvoorwaarden als reiskostenregelingen en kortingen op producten. Het meest is er aandacht voor spaarloonregelingen. Daarnaast wordt in veel apotheken werkoverleg gepleegd en vinden functioneringsgesprekken plaats. Persoonlijke en Bedrijfsontwikkelingsplannen zijn nog nauwelijks geïntroduceerd.

In grote apotheekgroepen worden wat meer faciliteiten geboden dan in andere apotheken. Zelfstandige apotheken en apotheken die deel uitmaken van een kleine groep houden zich daarentegen meer bezig met verzuimbegeleiding en leeftijdsbewust personeelsbeleid dan apotheken in grotere apotheekgroepen.

\section{Hoofdstuk 5 Effecten van HRM beleid}

Uit het onderzoek blijkt dat apotheken die flexibele werktijden aanbieden minder vacatures hebben. Bovendien worden in deze apotheken vacatures sneller vervuld en is het personeelsverloop kleiner. Mogelijk worden de apotheken die veel uren per dag open zijn als een aantrekkelijke werkgever gezien. Assistenten werken immers het liefst in deeltijd, en wel zo dat dit te combineren valt met eventuele zorgtaken.

Het aantal openstaande vacatures is eveneens geringer in apotheken waar functioneringsgesprekken gehouden worden. Functioneringsgesprekken zouden daarbij overigens meer in algemene zin een indicatie kunnen zijn van de zorg die men aan het welbevinden en de ontplooiingsmogelijkheden van het personeel besteedt. Verder is de productiviteit hoger in apotheken, waar veel aandacht is voor het om- en bijscholen van assistenten en nieuwkomers een hoger salaris wordt geboden. 
Een aantal HRM instrumenten lijkt echter negatieve effecten op de personeelsproblematiek te hebben. Het flexibel inzetten van apothekersassistenten door hen taken uit lagere functies te laten verrichten, vindt vooral plaats in apotheken met een relatief hoog personeelsverloop, relatief veel openstaande vacatures en een hoge werkdruk. In apotheken waar veel wordt overgewerkt vinden we bovendien een hogere werkdruk dan in apotheken waar dat niet of nauwelijks gebeurt.

Verder blijkt dat het ziekteverzuim onder apothekersassistenten hoog is wanneer er sprake is van prestatiebeloning. Dit zou erop kunnen wijzen dat assistenten die te maken hebben met deze vorm van beloning zich sneller opgejaagd voelen en zich daardoor eerder ziek melden. Ook blijkt het aantal openstaande vacatures hoger in apotheken waar prestatiebeloning wordt toegepast, dit lijkt er op te wijzen dat deze vorm van beloning niet populair is onder potentiële apothekersassistenten.

\section{Besluit}

De analyses in dit rapport laten zien dat apothekers op dit moment er nog niet in geslaagd zijn om de knelpunten in hun personeelsbeleid te verminderen door het voeren van een effectief HRM beleid. Met name het human resource development (HRD) beleid en het arbeidsvoorwaardenbeleid in de openbare apotheek werpen nog weinig vruchten af. Dit zou overigens kunnen komen doordat apothekers er niet in slagen de relatief gunstige arbeidsvoorwaarden die zij bieden kenbaar te maken naar (potentiële) sollicitanten en scholieren die voor een opleidingskeuze staan. Mogelijk ligt er een taak voor de apothekers om het gevoerde HRD- en arbeidsvoorwaardenbeleid meer naar buiten te brengen en te promoten.

Op grond van een eenmalige enquête is het echter moeilijk om de effectiviteit van het gevoerde HRM beleid goed te bepalen. Wanneer een apotheker aangeeft een specifiek HRM instrument in te hebben gezet, en deze apotheker heeft te maken met geringe knelpunten in de personeelsvoorziening, dan zouden we kunnen concluderen dat het HRM beleid gewerkt heeft. Andersom geldt echter ook dat juist de apothekers die te kampen hebben met moeilijk vervulbare vacatures, meer actie ondernemen om hun personeelsproblematiek te verminderen. Het HRM beleid is dan niet zozeer de oorzaak, maar veeleer het gevolg van de knelpunten in de personeelsvoorziening in de desbetreffende openbare apotheek.

Zo blijken apothekers die te kampen hebben met veel en lang openstaande vacatures en een hoog personeelsverloop vaker anders opgeleiden (bijvoorbeeld apotheekhulpen) aan te trekken, de opleidings- en ervaringseisen voor hun sollicitanten te verlagen en het Arbeidsbureau in te schakelen. Ook trachten apothekers met een hoge werkdruk en een hoog ziekteverzuim anders opgeleiden aan te trekken en nieuwe assistenten een hoger salaris te bieden. Door deze maatregelen te treffen hopen zij meer assistenten in de apotheek te kunnen aannemen, en zo de werkdruk voor de zittende apothekersassistenten te verminderen. Daarnaast bieden apothekers met een hoog zieketeverzuim hun assistenten vaker aanvullingen op de kinderopvangregelingen in de CAO aan. Dit wijst erop dat dit verzuim mogelijk mede het 
gevolg is van de problemen die apothekersassistenten ondervinden bij het combineren van werk en zorgtaken. De aanvullende regelingen maken het apothekersassistenten immers mogelijk om privé en werk beter te combineren.

Voor zover het dus gaat om recent ingezet beleid, of beleid dat juist wordt gevoerd vanwege de knelpunten in de personeelsvoorziening, zal het enige tijd kosten voordat de effecten van dit beleid zichtbaar worden. Om te onderzoeken of het recentelijk ingezette HRM beleid daadwerkelijk leidt tot een geringere personeelsproblematiek zullen de apothekers over een of twee jaar opnieuw bevraagd dienen te worden over hun knelpunten. 



\section{Inleiding}

De apothekersbranche kampt, net als veel andere branches in de zorgsector, al enkele jaren met grote knelpunten in de personeelsvoorziening. Het tekort aan apothekersassistenten is de laatste jaren dan ook een belangrijk punt van aandacht geworden. Een van de belangrijkste oorzaken voor het bestaan van deze knelpunten is de algehele krapte op de arbeidsmarkt voor middelbaar (en ook hoger) opgeleiden. Echter ook de structurele stijging van het geneesmiddelengebruik zorgt ervoor dat de behoefte aan mensen die deze zorg kunnen verlenen voortdurend toeneemt. De krapte op de arbeidsmarkt is daardoor binnen de openbare farmacie extra goed merkbaar.

Vanwege de krapte op de arbeidsmarkt storten ook bedrijven uit andere branches zich in de slag om schoolverlaters die voor de apothekersbranche interessant zijn. Een substantieel deel van het potentiële aanbod voor de branche vloeit om die reden weg naar andere branches. Cörvers et al. hebben berekend dat momenteel ongeveer 6.000 van de 29.000 gediplomeerde apothekersassistenten in Nederland in een baan buiten de apothekersbranche werkt. ${ }^{1} 53 \%$ Van hen werkt zelfs geheel buiten de gezondheidszorg. Voor hen was naast de zorg voor kinderen met name het gebrekkige carrièreperspectief binnen de branche een reden om niet als apothekersassistent aan de slag te gaan.

Doordat het steeds moeilijker wordt nieuwe medewerkers aan te trekken is er de apothekers veel aan gelegen dat het personeelsverloop beperkt blijft. Een dergelijke uitstroombeperking houdt vanzelfsprekend in dat het ook voor apotheken moeilijker wordt om gekwalificeerd personeel uit andere apotheken aan te trekken. Om ervoor te zorgen dat de slag om de schoolverlaters wordt gewonnen en dat de uitstroom van gekwalificeerd personeel beperkt blijft is er ook in de apothekersbranche een toename van de aandacht voor het zogenaamde 'human resource management' (HRM). Een goed HRM-beleid zorgt immers niet alleen voor het up to date houden van het aanwezige kennispotentieel, maar het zorgt ook voor het behoud van gekwalificeerde werknemers én het vergroot de aantrekkingskracht voor nieuw potentieel.

In die zin is het van belang om naast inzicht in de knelpunten in de personeelsvoorziening binnen de apothekersbranche, ook inzicht te krijgen in de mate waarin apothekers door hun HRM beleid de knelpunten in de personeelsvoorziening kunnen verminderen. Daarbij is op lange termijn niet alleen inzicht nodig in de mate waarin specifieke instrumenten worden ingezet, maar ook in de effectiviteit van de inzet van de verschillende beleidsinstrumenten.

Om afdoende antwoord te geven op bovengenoemde vragen is in het kader van de Arbeidsmarktmonitor Apothekersbranche in november 2001 voor de eerste keer een

1. Zie F. Cörvers, B.J. Diephuis en B. Golsteyn (2002). Het onbenutte arbeidspotentieel van apothekersassistenten voor de openbare apotheek, ROA-R-2002/2, Maastricht. 
enquête gehouden onder de apotheken in Nederland. In de enquête wordt informatie verzameld over:

- de actuele situatie in de apotheek;

- de knelpunten in de personeelsvoorziening;

- de manier waarop apotheken trachten deze knelpunten op te lossen.

Er werden door de SFK (Stichting Farmaceutische Kengetallen) in totaal 1.319 enquêtes verstuurd, wat leidde tot een respons van 549 apothekers. In dit rapport wordt verslag gedaan van de resultaten van deze werkgeversenquête. De representativiteit van de gebruikte gegevens is daarbij gewaarborgd, zowel naar regio als naar apotheekomvang. De representativiteit van de resultaten naar apotheektype kan helaas niet worden getoetst vanwege het ontbreken van landelijke gegevens hiervoor.

In hoofdstuk 2 zal eerst in algemene termen een aantal kenmerken van de apothekersbranche de revue passeren. Daarbij staan kenmerken als de soort apotheek, de omvang van de apotheek en de regio waarin apotheken zijn gevestigd centraal. Vervolgens wordt een beeld gegeven van de veranderingen die op dit moment plaatsvinden in de apotheek en de veranderingen in de functie en het werk van de apothekersassistenten. Ten slotte zal in hoofdstuk 2 worden ingegaan op de huidige personele bezetting van de apotheken. Daarbij gaat het om de leeftijdsopbouw van de op dit moment werkzame apothekersassistenten, het soort contract dat de assistenten hebben, het salaris dat zij verdienen, enzovoorts. Bovendien wordt het beeld dat de apothekers hebben van de competenties van hun apothekersassistenten in kaart gebracht en de mate waarin deze competenties aansluiten bij de veranderingen die zich in hun werk voordoen.

In hoofdstuk 3 wordt vervolgens gekeken naar de belangrijkste knelpunten in de personeelsvoorziening binnen de apothekersbranche. Hierbij wordt ingegaan op de factoren die van invloed kunnen zijn op de arbeidsmarktknelpunten, zoals de apotheekgrootte, het soort apotheek en de regio waarin de apotheek is gevestigd. Daarbij wordt in eerste instantie gekeken naar het aantal openstaande vacatures en het aantal langdurig openstaande vacatures. Ook wordt onderzocht hoe de vacatures zijn ontstaan en wat de belangrijkste problemen zijn bij het opvullen ervan.

Ook zal er gekeken worden naar de problemen die ontstaan als gevolg van het personeelsverloop in de openbare apotheek. Om een helder inzicht te krijgen in het personeelsverloop wordt niet alleen gekeken naar het aantal apothekersassistenten dat vertrekt en het aantal dat wordt aangenomen, maar ook naar de achterliggende oorzaken van het vertrek en de verwachtingen van apothekers als het gaat om het toekomstige verloop onder apothekersassistenten.

De personeelsschaarste heeft in combinatie met de structurele stijging van het geneesmiddelengebruik en de toenemende wens van apothekersassistenten om parttime te gaan werken bovendien geleid tot een verhoging van de werklast. 
Historisch gezien is de werklast zelfs nog nooit zo hoog geweest als nu. ${ }^{2}$ Omdat de hoge werklast tot een hogere werkdruk kan leiden en de hogere werkdruk op haar beurt weer een groter personeelsverloop tot gevolg kan hebben, is het van belang om te zien hoe apothekers de ontwikkeling van de werkdruk voor hun personeel beoordelen. Ook de ontwikkelingen op het gebied van de werkdruk en de verwachte gevolgen daarvan krijgen daarom in hoofdstuk 3 een plaats.

In hoofdstuk 4 wordt vervolgens uitgebreid ingegaan op de wijze waarop apothekers op de knelpunten in de personeelsvoorziening inspelen door middel van hun HRMbeleid. Allereerst wordt hierbij gekeken naar de werving van nieuw personeel. Hierbij gaat het om vragen als: welke maatregelen nemen apothekers om in moeilijk vervulbare vacatures te voorzien? Welke wervingskanalen worden gebruikt? In hoeverre doet de apotheker concessies aan de kwaliteit van nieuwe apothekersassistenten om ervoor te zorgen dat bezettingsproblemen uitblijven? Hierbij wordt ook gekeken naar de eventuele voorkeuren van apothekers voor herintreders, schoolverlaters ${ }^{3}$ of werknemers van andere apotheken. Naar aanleiding van de resultaten hiervan zal ook worden ingegaan op de manier waarop aan het stagebeleid gericht op BOL en BBL leerlingen wordt vormgegeven.

Ook het opleiden van het personeel dat men reeds in dienst heeft is een belangrijke manier om knelpunten in de personeelsvoorziening op te lossen. In hoofdstuk 4 wordt daarom ook uitgebreid ingegaan op het scholingsbeleid van de apotheken. Wat voor soort cursussen worden gevolgd, wie neemt daartoe het initiatief, enzovoorts. Ook wordt antwoord gegeven op de vraag in hoeverre door cursussen wordt ingespeeld op de veranderingen die in de apotheek plaatsvinden. In feite gaat het hier om een zogenaamde make or buy beslissing. Het laat immers zien in hoeverre apothekers ervoor kiezen door scholing ('make') de voor het goed functioneren van hun apotheek benodigde competenties te verkrijgen of juist door meer gekwalificeerde mensen op de arbeidsmarkt aan te trekken ('buy').

In hoofdstuk 4 wordt ook ingegaan op de mate waarin het flexibel inzetten van het aanwezige personeel wordt gebruikt voor het oplossen van knelpunten in de personeelsvoorziening. Hierbij wordt gekeken naar de mate waarin met werktijden van het personeel wordt geschoven, de mate waarin overwerk wordt verricht en de mate waarin apothekersassistenten taken verrichten die eigenlijk niet tot hun functie behoren.

Daarnaast wordt in hoofdstuk 4 een overzicht gegeven van de faciliteiten en arbeidsvoorwaarden die apothekers hun personeel aanbieden om ervoor te zorgen dat zij tevreden zijn met hun werk. Van deze faciliteiten kan ook een aanzuigende werking uitgaan bij de werving van nieuw personeel. Bovendien is een aantrekkelijk arbeids-

2. Zie: SFK-publicatie Farmacie in Cijfers "Hoge werkdruk in apotheken" Pharmaceutisch Weekblad, jaargang 137, nr 18.

3. Met een schoolverlater wordt iemand bedoeld die in het bezit is van een relevant vakdiploma. Een herintreder is iemand die eerder als apothekersassistent werkzaam was, maar die tijdelijk de openbare apotheek heeft verlaten. 
voorwaardenpakket een belangrijk middel bij het beperken van het personeelsverloop.

Om te bepalen in hoeverre de apothekersbranche door middel van het gevoerde HRM beleid ook degenen die niet meer werkzaam zijn in een apotheek (het 'onbenutte arbeidspotentieel' of 'de stille reserve') kan aanspreken wordt ten slotte een vergelijking gemaakt tussen de faciliteiten die de apothekersbranche op dit moment aanbiedt en datgene wat deze stille reserve te wensen heeft. Deze vergelijking gebeurt mede aan de hand van gegevens uit een eerder verschenen rapport in het kader van de Arbeidsmarktmonitor Apothekersbranche. ${ }^{4}$

Aan de hand van verklarende analyses wordt in hoofdstuk 5 nagegaan of het gevoerde HRM-beleid ervoor zorgt dat er in bepaalde apotheken of regio's opvallend minder vacatures voor apothekersassistenten openstaan, of dat de openstaande vacatures vanwege specifieke inspanningen juist sneller kunnen worden opgevuld. Daarbij wordt uiteraard ook onderzocht in hoeverre bepaalde kenmerken van apotheken zoals de omvang en soort apotheek daarop van invloed zijn. Vervolgens wordt gekeken naar de effecten van het gevoerde HRM-beleid op het personeelsverloop, de werkdruk, het ziekteverzuim en naar de gevolgen van het gevoerde HRM-beleid voor de productiviteit van de openbare apotheek. Op deze wijze kan worden nagegaan in hoeverre apothekers door middel van hun HRM beleid de knelpunten in de personeelsvoorziening kunnen verhelpen door bijvoorbeeld meer te investeren in bepaalde facetten van het HRM beleid.

Hoofdstuk 6 sluit het rapport af met een opsomming van de belangrijkste conclusies uit het rapport en een aantal aanbevelingen om de knelpunten in de personeelsvoorziening in de openbare apotheek te verminderen.

4. Zie F. Cörvers, B.J. Diephuis en B. Golsteyn (2002). Het onbenutte arbeidspotentieel van apothekersassistenten voor de openbare apotheek, ROA-R-2002/2, Maastricht. 


\section{Actuele situatie en ontwikkelingen in de sector}

In dit hoofdstuk worden enkele algemene kenmerken van de apothekersbranche in kaart gebracht. Daarbij wordt ook een beeld geschetst van de belangrijkste veranderingen in en rond de apotheek en in de functie van de apothekersassistenten. Bovendien wordt een uitgebreide beschrijving gegeven van het personeel dat op dit moment werkzaam is in de apothekersbranche. Hierbij wordt gekeken naar onder andere leeftijdsopbouw, baanduur en het salaris. Ook wordt dieper ingegaan op het beeld dat apothekers hebben van de competenties van hun apothekersassistenten. Het hoofdstuk sluit af met een beschrijving van de mate waarin de competenties van de apothekersassistenten aansluiten bij de veranderingen die op dit moment in hun werkzaamheden plaatshebben.

\subsection{De openbare apotheek}

Het aantal openbare apotheken is in de afgelopen 10 jaar gestaag gestegen. In 1992 was Nederland bijna 1.500 openbare apotheken rijk. Inmiddels is dat aantal gestegen tot 1.629 in 2001. Dat betekent een gemiddelde jaarlijkse stijging van het aantal openbare apotheken met $0,9 \%$. De laatste vijf jaar stijgt het aantal echter sneller. Tussen 2000 en 2001 steeg het aantal openbare apotheken zelfs met 1,7\%. De toename wordt grotendeels veroorzaakt door de toenemende vraag naar zorg en geneesmiddelen. ${ }^{5}$

Figuur 2.1 laat zien dat de meeste apotheken in Nederland nog steeds zelfstandig zijn, ruim $65 \%$. Slechts $35 \%$ van de apotheken behoort tot een apotheekgroep, waarvan de meerderheid tot een kleine groep van maximaal 4 apotheken behoort. Het gaat bij apotheekgroepen om zowel de onafhankelijke apothekers die in plaatselijk verband samenwerken uit strategische overwegingen (en mede-eigenaar zijn van een maatschap) als om landelijk opererende (franchise) formules waarbij de afzonderlijke vestigingen gespreid gevestigd zijn. De figuur laat ook zien hoe de apotheken regionaal zijn verspreid.

In de regio's Noord en Zuidwest opereren de apotheken wat minder vaak zelfstandig dan in de andere regio's. Vooral het verschil met de regio Middenwest is groot, zo'n $15 \%$-punt. Ook zijn er grote regionale verschillen wanneer we kijken naar het aandeel van de grote apotheekgroepen van 5 of meer apotheken. In de regio's Zuidwest en Zuidoost is ruim $20 \%$ van de apotheken onderdeel van een grote apotheekgroep. In de regio's Noordwest, Middenwest en Oost ligt dat percentage ruim 10\%-punt lager.

In figuur $2.2 \mathrm{a}$ is per regio de omvang van de apotheken aangegeven. De omvang van een apotheek is vastgesteld op basis van het aantal WTG-verstrekkingen dat

5. Zie: J.L. Tinke. en A.M.G.F. Griens (2001). Data en Feiten 2001, SFK, Den Haag. 
jaarlijks door een apotheek wordt verzorgd. De gebruikte indeling is mede gebaseerd op een eerder door het IVA gebruikte indeling. ${ }^{6}$

\section{Figuur 2.1}

Soort apotheek, naar regio, 2001

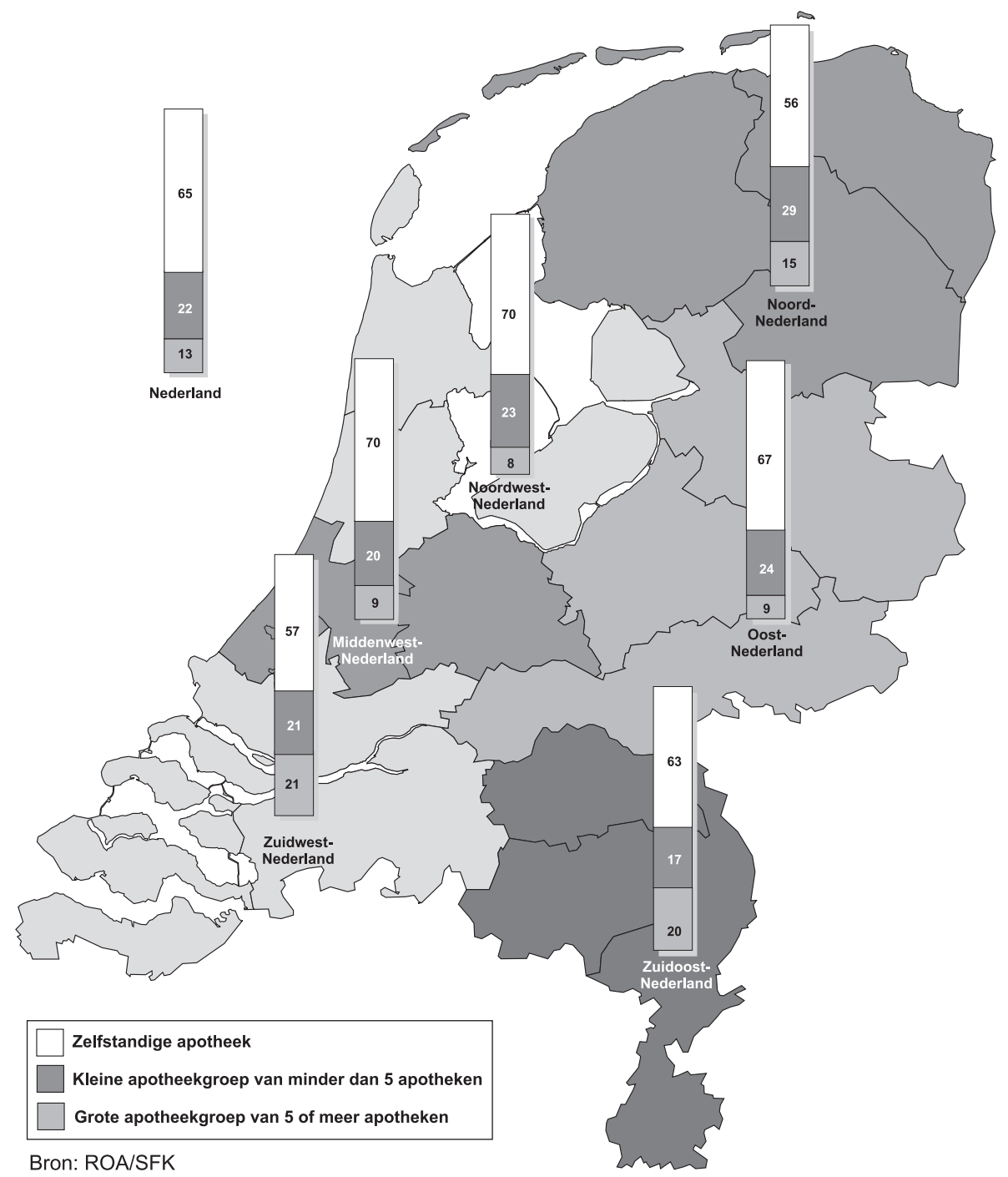

Figuur 2.2a laat zien dat apotheken in de regio's Zuidoost en Middenwest gemiddeld genomen het kleinst zijn, wanneer we kijken naar het aantal voorschriften. Slechts $40 \%$ van de apotheken in deze regio's behoort tot de grote tot erg grote apotheken. Erg grote apotheken zien we voornamelijk in de regio Noordwest, waar zo'n 30\% van de apotheken tot de 'zeer grote' apotheken gerekend kan worden.

6. Zie G.H.M. Evers, M. van Moorsel en H. van der Werff jr. (2001). Functiedifferentiatie binnen de apothekersbranche, Tilburg, 2001. 
Figuur 2.2a

Apotheekomvang in aantal WTG-verstrekkingen per jaar, naar regio, 2001

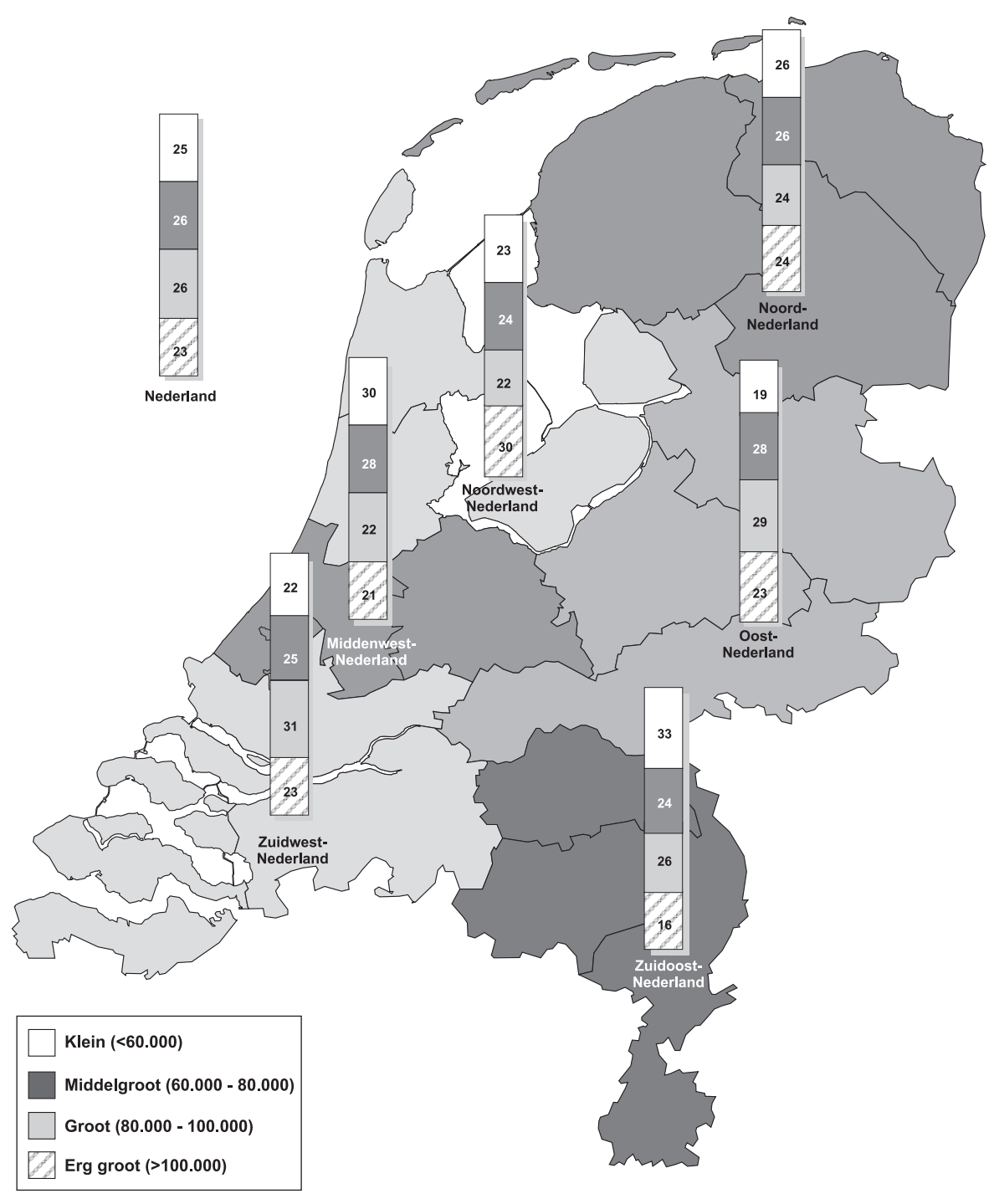

Bron: ROA/SFK

Analyse maakt verder duidelijk dat de apotheken die tot een apotheekgroep van meer dan 5 apotheken behoren over het algemeen relatief klein zijn. Zelfstandige apotheken zijn over het algemeen wat groter. Dat wijst erop dat met name kleinere apotheken zoeken naar samenwerkingsvormen en dat grotere apotheken er juist voor kiezen zelfstandig te opereren. Een mogelijke verklaring hiervoor is overigens dat apotheken die groeien er vaak voor kiezen een tweede vestiging te openen. Daardoor ontstaan uit een grote apotheek die zelfstandig opereerde, twee kleine apotheken die samenwerken. 
Kijken we naar de apotheekomvang in termen van het aantal werknemers (figuur $2.2 b)^{7}$ dan blijken vooral in de regio Oost relatief veel grote tot erg grote apotheken gevestigd te zijn. 50\% Van de apotheken in deze regio is (erg) groot. Klein zijn de apotheken in de regio's Noord en Noordwest. Meer dan 35\% van de apotheken in deze regio's behoort tot de kleinste categorie.

Figuur 2.2b

Apotheekomvang in aantal werknemers, naar regio, 2001

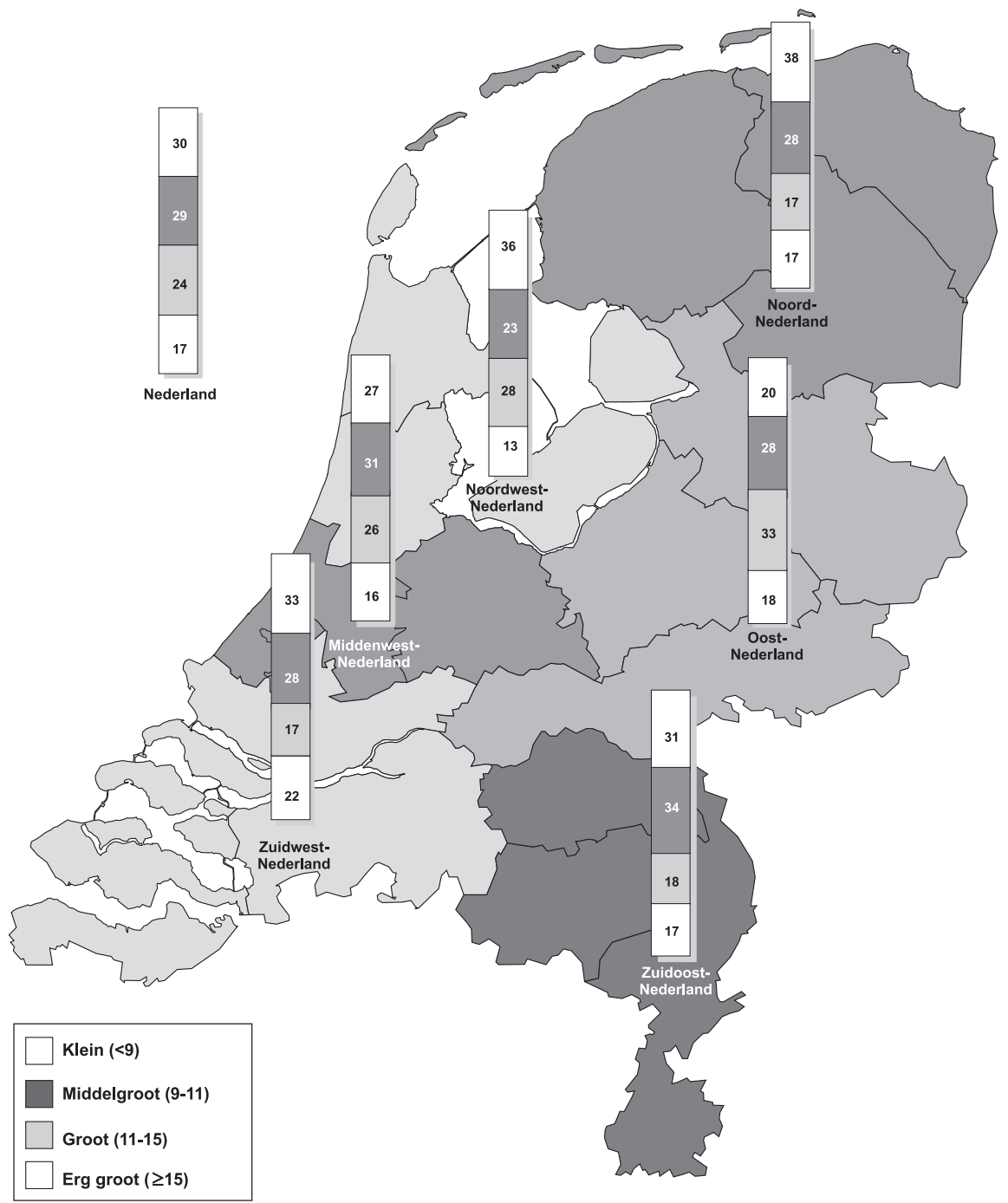

Bron: ROA/SFK

7. Wanneer in dit rapport een verbijzondering wordt gemaakt naar apotheekomvang wordt alleen een onderscheid gemaakt tussen omvang naar WTG-voorschriften en omvang naar het aantal werknemers als daar vanwege opvallende verschillende resultaten aanleiding toe is.

8 


\subsection{Veranderingen in de apothekersbranche}

De laatste jaren is er heel wat veranderd in en rond de apothekersbranche. Deze veranderingen hebben onder andere hun weerslag op de inhoud van het werk dat de apothekersassistenten binnen de apotheek doen. Bevolkingsgroei, vergrijzing, de verschuiving van de zorg naar de thuissituatie en de forse uitbreiding van het productaanbod hebben ervoor gezorgd dat het geneesmiddelengebruik de laatste jaren sterk is gestegen. ${ }^{8}$ Gezien de structurele aard van de demografische ontwikkelingen en de uitbreiding van het productaanbod zal deze trend zich waarschijnlijk ook in de komende jaren voortzetten. Apothekers anticiperen bovendien op veranderingen in wet- en regelgeving, die hen meer bevoegdheden geven als zorgverlener.

In deze paragraaf wordt dieper ingegaan op de veranderingen die apothekers percipiëren in hun eigen apotheek of de omgeving ervan. Figuur 2.3 laat zien dat in nagenoeg alle apotheken belangrijke veranderingen plaatsvinden. De belangrijkste verandering is de intensivering van de patiëntenzorg. Andere veranderingen die in relatief veel apotheken een rol spelen zijn de toenemende klantgerichtheid, de mondigheid van cliënten en het afnemende aantal medicijnbereidingen door apothekersassistenten. Vooral service en klantencontact worden dus steeds belangrijker. Vaktechnische veranderingen daarentegen zijn veel minder aan de orde. Nieuwe computersystemen of bijvoorbeeld productvernieuwingen spelen voor nog geen $20 \%$ van de apothekers voor veranderingen in het werk van de assistenten.

De mondigheid van cliënten en de snellere vernieuwing van het productaanbod worden wat vaker genoemd door vertegenwoordigers van zelfstandige apotheken. Apothekers die deel uitmaken van een kleine apotheekgroep noemen daarentegen relatief vaak de koppeling met artsensystemen als belangrijke verandering. In grote keten-apotheken wordt vooral klantgerichtheid genoemd als een gebied waarop veranderingen plaatsvinden.

De verhoging van de werklast vormt vooral voor apothekersassistenten in apotheken die deel uitmaken van een grote apotheekgroep een potentieel probleem. Bijna de helft van de apothekers in deze apotheken geeft aan bij de apothekersassistenten een verhoging van de werklast te ervaren. Van de overige apotheken geeft slechts één op de drie aan dat er sprake is van een verhoging van de werklast bij apothekersassistenten. Het gegeven dat met name in de grote apotheekgroepen de uitbreiding van de handverkoop als belangrijke verandering in het werk wordt genoemd, maakt de situatie qua werklast in deze apotheken mogelijk extra zorgelijk. Uit de enquête blijkt echter ook dat apotheken die deel uitmaken van een grote apotheekgroep voorop lopen als het gaat om het beperken van het aantal bereidingen en het in gebruik nemen van nieuwe computersystemen. Uit het laatste kan echter niet zonder meer de conclusie worden getrokken dat apotheekgroepen op automatiseringsgebied voorop lopen. Het in gebruik nemen van nieuwe computersystemen kan immers ook een gevolg zijn van het feit dat apotheekgroepen de computersystemen

8. Zie: J.L. Tinke. en A.M.G.F. Griens (2001). Data en Feiten 2001, SFK, Den Haag. 
op elkaar willen afstemmen vanwege de mogelijke schaalvoordelen die dit biedt. Ook de afname van het aantal bereidingen zou hiermee kunnen samenhangen.

\section{Figuur 2.3}

Percentage apotheken dat aangeeft te worden geconfronteerd met een bepaald soort veranderingen, 2001

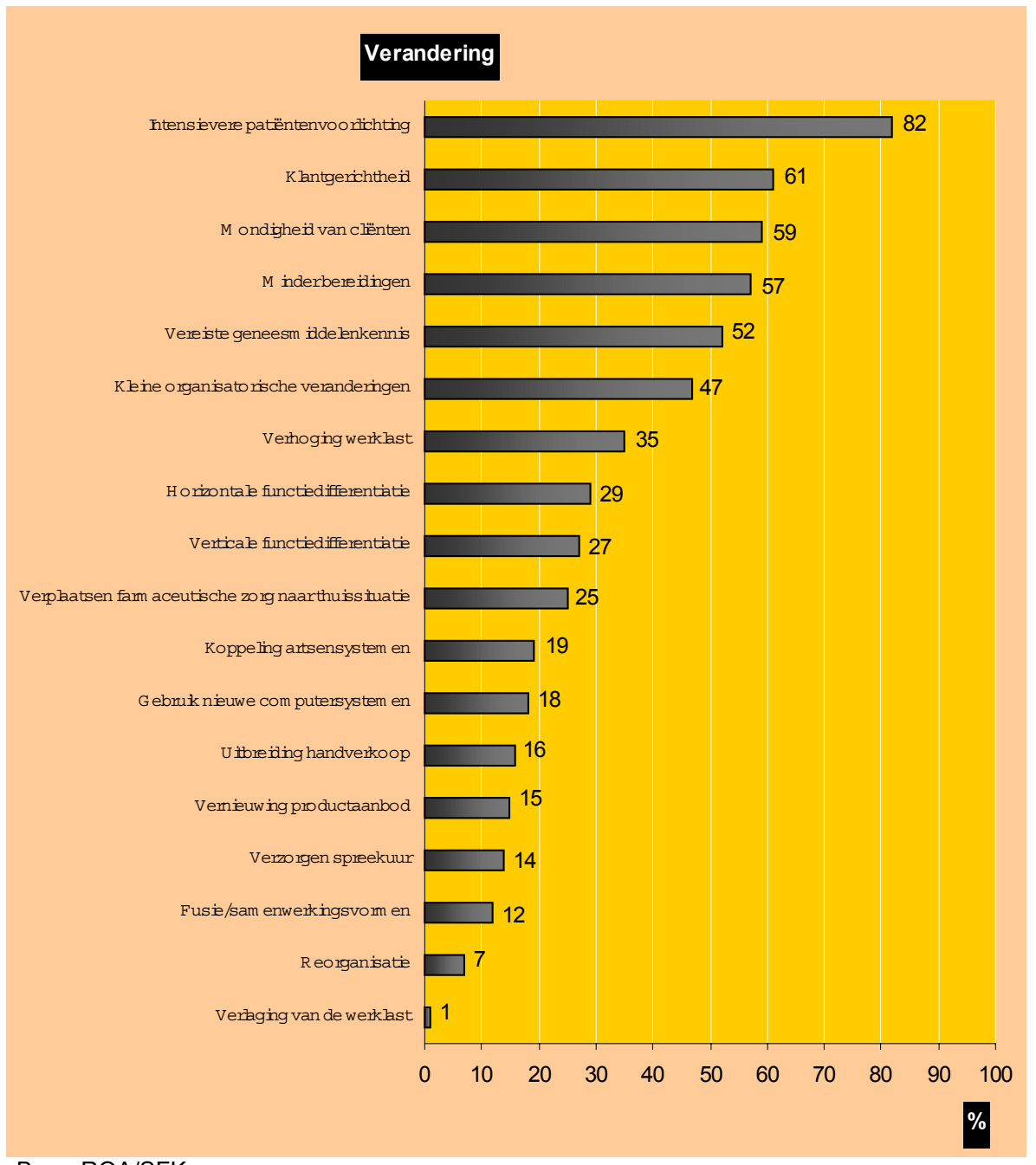

Bron: ROA/SFK

Een regionale vergelijking laat zien dat apothekers in de regio Noord minder veranderingen zien in de werkzaamheden van de apothekersassistent dan de apotheken in de rest van Nederland. Er zijn echter nauwelijks regionale verschillen wanneer het gaat om het soort veranderingen dat plaatsvindt. Intensievere patiëntenvoorlichting is in alle regio's met afstand de meest genoemde verandering (ruim $80 \%$ van de apotheken). Verder behoren klantgerichtheid, mondigheid, vereiste geneesmiddelenkennis en het doen van minder medicijnbereidingen steevast tot de vijf belangrijkste veranderingsgebieden. Een verhoging van de werklast bij apothekersassistenten wordt met name door apothekers in de regio Noordwest ervaren. $41 \%$ Van de apo10 
thekers noemt de verhoging van de werklast als een belangrijke verandering. In de regio Zuidwest is het percentage apotheken dat een verhoging van de werklast constateert zo'n 10\%-punt lager. In de regio Oost wordt ten slotte de verplaatsing van farmaceutische zorg naar de thuissituatie wat vaker genoemd dan in andere regio's en in de regio Zuidoost is er minder vaak sprake van veranderingen op het terrein van het verzorgen van spreekuren dan in andere regio's.

Het belang van patiëntvoorlichting, klantgerichtheid en andere veranderingen in de omgang met klanten is vooral groot in de grotere apotheken. Ook functiedifferentiatie en een verhoging van de werklast zijn vooral veranderingen in het werk van apothekersassistenten in grotere apotheken. De uitbreiding van de handverkoop en veranderingen in de vereiste geneesmiddelenkennis spelen daarentegen vooral in kleine apotheken een rol.

Het contact met de cliënt wordt duidelijk een steeds belangrijker aspect van het werk van de apothekersassistenten, of dat nu komt door de intensivering van de patiëntenvoorlichting of door de toenemende mondigheid van cliënten. De veranderingen maken in ieder geval duidelijk dat er steeds meer een beroep wordt gedaan op de communicatieve vaardigheden van de apothekersassistent. Niet alleen in de alledaagse omgang met klanten in de zin van klantvriendelijkheid maar zeker ook vakinhoudelijk. Apothekersassistenten zullen steeds beter in staat moeten zijn om de cliënt goede voorlichting te geven en duidelijke en heldere antwoorden te formuleren op de vragen die op hen afkomen over specifieke medicijnen of andere producten. Dit blijkt uit het feit dat apothekers aangeven dat er niet alleen veranderingen plaatsvinden op het gebied van klantvriendelijkheid en het kunnen omgaan met mondige cliënten, maar dat de veranderingen ook betrekking hebben op de vereiste geneesmiddelenkennis.

Opvallend zijn in dit licht enkele resultaten van de enquête onder het onbenutte arbeidspotentieel van apothekersassistenten (Cörvers et al., 2002). Op de vraag op welke terreinen potentiële herintreders denken een opfriscursus nodig te hebben worden communicatieve vaardigheden immers het minst genoemd. Enerzijds kan dit betekenen dat de meeste potentiële herintreders zelf denken voldoende communicatieve vaardigheden in huis te hebben. Anderzijds kan het betekenen dat de herintreders zich onvoldoende bewust zijn van de eisen die er in de apotheek op het gebied van communicatie zullen worden gesteld als zij weer aan het werk gaan.

\subsection{Personeel in de openbare apotheek}

Om een goed beeld te krijgen van de apothekersbranche en de knelpunten en uitdagingen die op de branche afkomen zal vanzelfsprekend ook de aandacht moeten uitgaan naar een aantal sleutelkenmerken van de apothekersassistenten die op dit moment werkzaam zijn in de openbare apotheek. In deze paragraaf zal daarom worden gekeken naar kenmerken zoals leeftijd, baanduur en salaris van apothekersassistenten. Bovendien zal dieper worden ingegaan op het beeld dat de apothekers hebben van de competenties van hun apothekersassistenten en in hoeverre deze competenties aansluiten bij veranderingen die in hun werk binnen de openbare 
apotheek zichtbaar zijn. Ook in deze paragraaf worden gegevens telkens verbijzonderd naar soort apotheek, regio en omvang. In tabel 2.1 wordt een overzicht gegeven van de belangrijkste kengetallen.

Leeftijd

Tabel 2.1 laat allereerst zien dat van alle werknemers in de openbare apotheek bijna $80 \%$ werkzaam is als apothekersassistent. De gemiddelde leeftijd van de apothekersassistenten ligt iets boven de 36 jaar. Assistenten die werkzaam zijn in zelfstandige apotheken of kleine apotheekgroepen zijn gemiddeld ongeveer één jaar ouder dan assistenten die in grote apotheekgroepen werkzaam zijn. Ook is er een behoorlijk leeftijdsverschil tussen de regio's. In de regio's Noordwest en Middenwest zijn de apothekersassistenten met ruim 38 jaar gemiddeld het oudst. In de regio Noord is de apothekersassistent gemiddeld zo'n 3,5 jaar jonger.

Kijken we naar de verdeling in leeftijdscategorieën dan blijkt dat zo'n 16\% van de apothekersassistenten jonger is dan 25 jaar; $31 \%$ is $25-35$ jaar; $27 \%$ is $35-45$ jaar; $21 \%$ is $45-55$ jaar en $6 \%$ is 55 jaar of ouder. In de regio's Noord, Noordwest en Middenwest is de oudste leeftijdscategorie met ruim $7 \%$ relatief groot. De jongste leeftijdsgroep is vooral in de regio Zuidwest goed vertegenwoordigd (18\%). Of een apotheek zelfstandig is of deel uitmaakt van een groep maakt geen verschil voor de spreiding van de leeftijd van de assistenten. Datzelfde geldt voor de omvang van de apotheek. Of het om een kleine of grote apotheek gaat maakt nauwelijks verschil voor de leeftijdsopbouw van het personeel.

\section{Baanduur}

De apothekersassistenten verblijven gemiddeld zo'n 7 jaar in hun huidige functie bij hun huidige werkgever. Dat is een baanduur die vergelijkbaar is met die van de gemiddelde werknemer in Nederland. ${ }^{9}$ In de apotheken die tot een groep van meer dan 5 apotheken behoren is de gemiddelde baanduur bijna een jaar korter dan die in zelfstandige apotheken of apotheken die deel uitmaken van kleinere groepen. De gemiddeld lagere leeftijd van de assistenten in de grotere apotheekgroepen zal daar zeker verband mee houden. De kortere baanduur van de assistenten die werkzaam zijn in de grote apotheekgroepen kan ook het gevolg zijn van het feit dat de groepsvorming iets is van de laatste jaren en groepsvorming vaak gepaard gaat met met het aantrekken van nieuwe assistenten.

De regionale verschillen zijn niet zo groot. In de regio Noord verblijven apothekersassistenten gemiddeld het minst lang bij hun huidige werkgever (6,2 jaar). Ook hier speelt de leeftijd van de assistenten waarschijnlijk een belangrijke rol. In de regio Noordwest hebben de assistenten gemiddeld de langste baanduur (7,5 jaar). In deze regio zijn zij ook het oudst. Opvallend is overigens ook dat assistenten in de regio Oost relatief jong zijn, maar wel een relatief lange baanduur hebben. Mogelijk heeft dit te maken met het feit dat in de regio Oost relatief weinig herintreders in dienst

9. Zie A. de Grip en J. Sanders (2000). Naar een employability monitor, ROA-R-2000/9, Maastricht. 
genomen zijn. Ook is het mogelijk dat in de regio Oost assistenten liever op hun plek blijven zitten en niet zo snel van werkgever veranderen. De afstanden tussen apotheken in een minder dicht bevolkte regio als de regio Oost kunnen van invloed zijn. Assistenten vinden, zo blijkt uit analyses verderop in dit rapport, lange reistijden immers bezwaarlijk.

Kijken we naar de omvang van de apotheek (zowel qua aantal werkenden als qua aantal receptregels), dan valt op dat vooral in kleine apotheken de baanduur aan de korte kant is. Voor het overige zijn de verschillen gering.

\section{Salaris}

Gemiddeld verdienen apothekersassistenten per maand $€ 1.775,00$ bruto op basis van een fulltime baan. Het salaris ligt ruim boven het niveau van het salaris dat assistenten gezien hun gemiddelde baanduur van 7 jaar volgens de CAO van 2001 zouden moeten verdienen, ook wanneer rekening wordt gehouden met eventuele diplomatoeslagen. In de apothekersbranche is het waarschijnlijk dat assistenten gemiddeld één diplomatoeslag halen. Dat betekent dat hun salaris na 7 jaar dienstverband zo'n $€ 1614,00$ zou bedragen. Een mogelijke verklaring voor het gevonden verschil is dat vooral assistenten die wat langer in dienst zijn diplomatoeslagen halen. Apothekers kunnen echter ook besluiten assistenten wat meer te betalen om knelpunten op te lossen. Ook zou het verschil gedeeltelijk kunnen worden verklaard door de toeslag voor het werken op onregelmatige werktijden.

Assistenten van apotheken die deel uitmaken van een kleinere apotheekgroep zitten met een salaris van $€ 1.803,00$ boven het gemiddelde. Zij verdienen $€ 28,00$, gemiddeld per maand meer dan assistenten in de zelfstandige apotheek, of assistenten in apotheken die tot een grote apotheekgroep behoren. Het salarisverschil met de assistenten die werken in apotheken die tot de grotere apotheekgroepen behoren is te verklaren uit het feit dat de apothekersassistenten in kleine apotheekgroepen gemiddeld één jaar ouder zijn.

Het gemiddelde brutomaandsalaris van apothekersassistenten in de regio's Middenwest en Noordwest ligt zo'n $€ 30,00$ boven het landelijk gemiddelde. Gezien de gemiddeld hoge leeftijd van de apothekersassistenten in deze regio's is dat echter niet zo verwonderlijk. Daarnaast kan het samenhangen met de grotere krapte op de arbeidsmarkt in deze regio's (zie paragraaf 3.2). In de regio's Noordwest en Middenwest is immers de vacaturegraad het hoogst. In de regio Noord ligt het gemiddelde brutomaandsalaris het laagst ( $€ 1.731,00$ ). Ook hiervoor vormt de situatie op de arbeidsmarkt en de leeftijd van de assistenten waarschijnlijk de verklaring. Opvallend is in dat opzicht wel dat het salaris van de assistenten in de regio Oost zo'n $€ 30,00$ hoger ligt dan in de regio Zuidoost, terwijl in de regio Zuidoost de gemiddelde leeftijd wat hoger is en de baanduur ongeveer gelijk ligt.

Mogelijk gekoppeld aan de gemiddeld wat kortere baanduur van assistenten in de kleinste apotheken ligt ook het gemiddelde brutomaandsalaris wat lager. De verschillen zijn echter beperkt. 


\section{Verzuimpercentage}

Tabel 2.1 geeft ook weer dat het verzuimpercentage onder apothekersassistenten op het moment van afname van de vragenlijst voor veel apotheken oploopt tot zo'n $7,5 \% .{ }^{10}$ Het gaat hier om 285 apotheken die de vragenlijst op dit punt invulden. Dat is duidelijk hoger dan het landelijk gemiddelde van 5,5\%, maar vergelijkbaar met het verzuimpercentage binnen de sector welzijn en gezondheidszorg. Het ziekteverzuimpercentage van $8 \%$ is echter mogelijk een overschatting. Het percentage is gebaseerd op de apotheken die de enquêtevraag naar het verzuim hebben beantwoord. Maar liefst $50 \%$ van de apotheken die aan het onderzoek hebben deelgenomen heeft echter de vraag naar het ziekteverzuim niet beantwoord. Mogelijk is in een deel van deze apotheken het verzuim nihil. In dat geval ligt het gemiddeld ziekteverzuim op een lager niveau dan hier wordt gepresenteerd.

Het verzuim in de grote apotheekgroepen ligt met $11 \%$ overigens op een hoger niveau. Binnen de zelfstandige apotheken en de apotheken in kleinere apotheekgroepen ligt het verzuimpercentage lager, namelijk op $7 \% .{ }^{11}$ De regionale verschillen zijn klein. In de regio Middenwest is het verzuim met $6 \%$ het laagst. In de regio Oost is het met ruim $8 \%$ het hoogst.

Voor het verzuim van assistenten maakt het nauwelijks verschil of het om een kleine of grote apotheek gaat qua aantal werknemers. Kijken we naar omvang in termen van aantal voorschriften per jaar dan zien we een groter onderscheid. De apotheken waar de meeste voorschriften worden uitgeschreven hebben wat minder verzuim dan de apotheken waar minder dan 60.000 voorschriften worden uitgeschreven. Omdat de relatie tussen verzuim en aantal voorschriften niet eenduidig is, mag echter niet direct een conclusie worden verbonden aan de gevonden verschillen. Het ligt immers voor de hand dat apotheken met een laag verzuim een hogere productiviteit hebben.

\section{Achtergrond van de apothekersassistenten}

Om te kunnen bepalen in hoeverre schoolverlaters, herintreders en apothekersassistenten ${ }^{12}$ met een andere achtergrond instromen in de openbare apotheek is in tabel 2.1 ook een overzicht gegeven van de herkomst van de apothekersassistenten. In vrijwel iedere apotheek worden zowel herintreders als schoolverlaters in dienst genomen. Het gemiddelde aantal herintreders per apotheek is echter slechts 2 (gemiddeld 1 fulltime baan), terwijl het gemiddelde aantal apothekersassistenten dat

10. Dit is exclusief het verzuim op grond van zwangerschapsverlof. Dit percentage is mogelijk een overschatting. Mogelijk hebben apotheken zonder verzuim de betreffende vraag in de enquête overgeslagen, waardoor zij als zogenaamde 'missings' niet worden meegenomen in de analyses. Afhankelijk van de wijze waarop deze missings worden behandeld ligt het verzuimpercentage tussen de 5 en $7,5 \%$.

11. Of deze cijfers voor wat betreft het soort apotheek representatief zijn, is niet aan te geven.

12. Schoolverlaters zijn apothekersassistenten die rechtstreeks vanuit de opleiding tot apothekersassistent zijn ingestroomd in de openbare apotheek. Herintreders zijn assistenten die gedurende een langere periode niet actief zijn geweest op de arbeidsmarkt en weer terugkeren. Herintreders hebben voordat zij de arbeidsmarkt tijdelijk verlieten wel gedurende enkele jaren in de apothekersbranche als apothekersassistent gewerkt. 


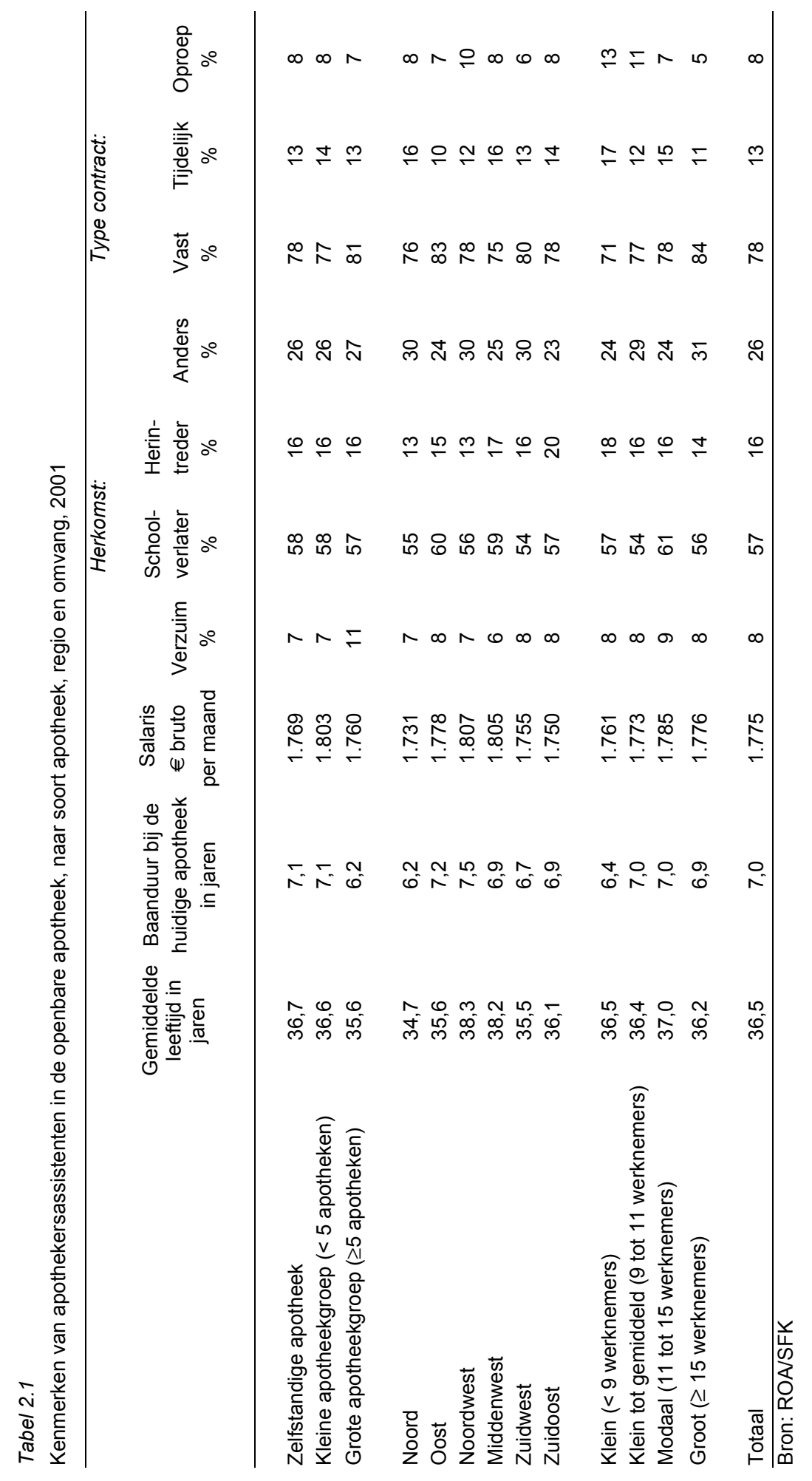


als schoolverlater in dienst is genomen aanzienlijk hoger ligt op bijna 8 (gemiddeld 6 fulltime baan). De meerderheid van de werkzame apothekersassistenten is dan ook aangetrokken als schoolverlater van een opleiding tot apothekersassistent (57\%). $16 \%$ Van de assistenten is herintreder en $26 \%$ heeft een andere achtergrond. Zij komen bijvoorbeeld van een andere apotheek, waren elders werkzaam of waren werkloos.

Er zijn geen verschillen tussen de onderscheiden soorten apotheken als het gaat om de herkomst van de apothekersassistent. Ook de regionale verschillen zijn erg klein. Wel blijkt dat in de regio Oost en Middenwest naar verhouding wat meer schoolverlaters werkzaam zijn dan in andere regio's. In de regio Zuidoost werken daarentegen relatief veel herintreders (20\%). Voorts blijkt dat grotere apotheken wat meer schoolverlaters in dienst hebben. In kleine apotheken werken wat meer herintreders. Ook hier zijn de verschillen niet groot.

\section{Contractvorm}

78\% Van de apothekersassistenten heeft een vast contract, zo blijkt uit tabel 2.1. $13 \%$ Van de contracten is tijdelijk en $8 \%$ van de apothekersassistenten heeft een oproepcontract. Voor het overige zijn er nauwelijks verschillen tussen de verschillende soorten apotheken. Wel zijn er enkele regionale verschillen. Apotheken in de regio's Oost en Zuidwest hebben naar verhouding wat meer assistenten voor vast in dienst. Het verschil met de regio's Noord en Middenwest is daarbij het grootst. In deze regio's zijn dan ook relatief veel assistenten in tijdelijke dienst. Oproepcontracten ten slotte komen we wat meer tegen in de regio Noordwest. Opvallend grote regionale verschillen zijn er echter niet. Ook de omvang van de apotheek heeft duidelijk een effect op de contractvorm. Naarmate de apotheek in omvang toeneemt is het aandeel van de assistenten dat een vast contract heeft groter, terwijl het percentage met een oproepcontract juist afneemt. Ook tijdelijke contracten zijn er in kleine apotheken naar verhouding wat meer dan in de erg grote apotheken.

\section{Competenties}

Inzicht in de competenties van de apothekersassistenten binnen de openbare apotheek is van groot belang om te kunnen bepalen in hoeverre de momenteel werkzame apothekersassistenten volgens de apotheker kunnen voldoen aan de eisen die hun werk stelt. In figuur 2.4 wordt aangegeven in hoeverre de apothekersassistenten volgens de apotheker over een aantal belangrijke competenties beschikken.

Uit de figuur kan zonder meer worden geconcludeerd dat apothekers vinden dat ze over het algemeen competente apothekersassistenten in dienst hebben. Gemiddeld scoren de assistenten een dikke 7. Het meest competent vinden de apothekers hun assistenten op het terrein van het recepteren van geneesmiddelen, het omgaan met collega's en hun zelfstandigheid (allen 7,7). Op deze gebieden worden dan ook de minste onvoldoendes gescoord. Voor het recepteren van geneesmiddelen geven de apothekers zelfs helemaal geen onvoldoendes. 


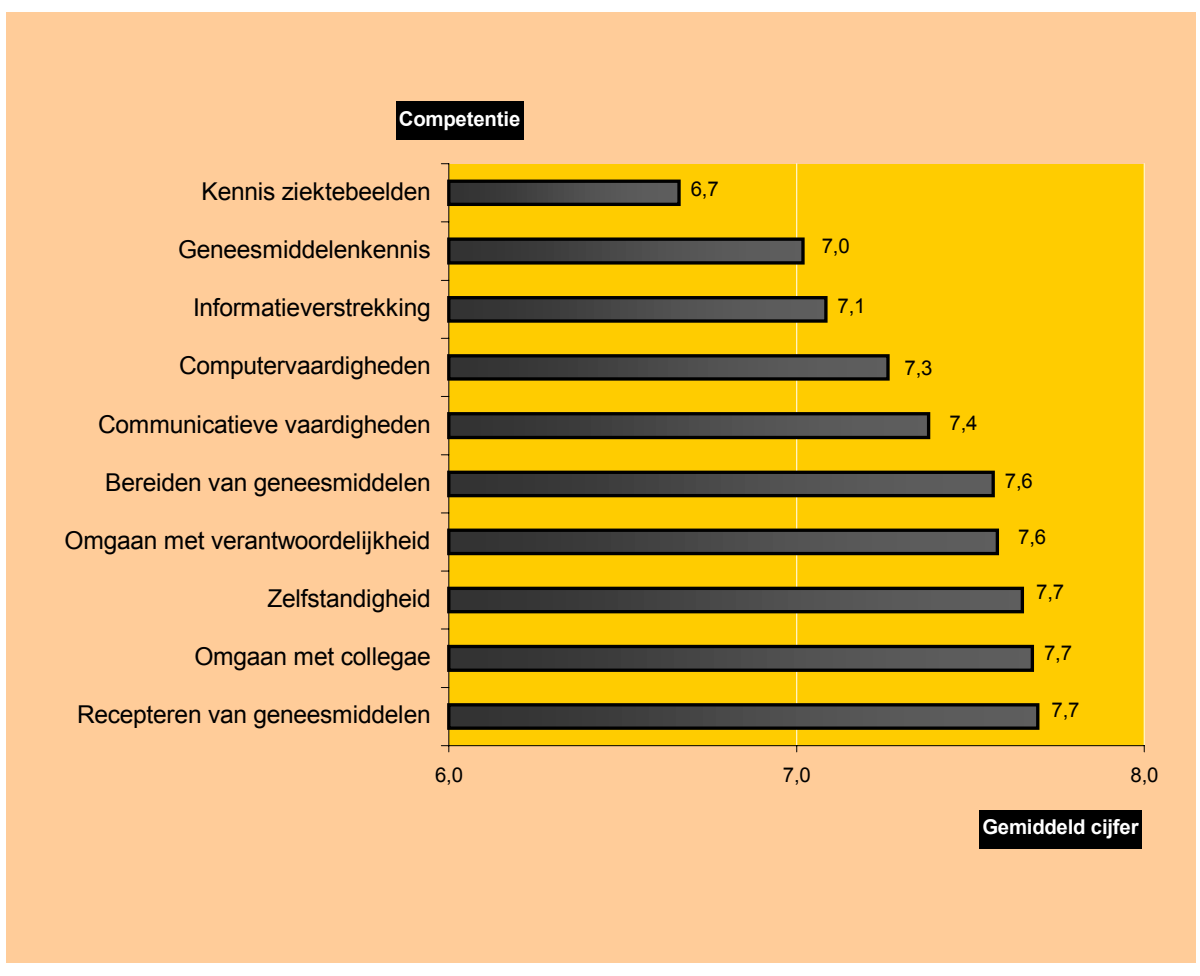

\section{Bron: ROA/SFK}

De assistenten scoren wat minder goed wanneer het gaat om hun vakinhoudelijke kennis, hoewel er zowel qua geneesmiddelenkennis, als qua kennis van ziektebeelden nog altijd met respectievelijk een 7,0 en een 6,7 ruim voldoende wordt gescoord. Ruim 9\% van de apothekers geeft hun apothekersassistenten op het punt van de kennis van ziektebeelden echter een onvoldoende (5 of lager).

De gemiddelde competentiescore in de grote apotheekgroepen (5 of meer apotheken) ligt wat lager dan de scores in kleine apotheekgroepen. Het percentage onvoldoendes is dan ook over het algemeen in de apotheken die deel uitmaken van een grote groep wat hoger dan elders. Voor het verstrekken van informatie en de kennis van geneesmiddelen is het verschil tussen de grote groepsapotheken en de andere apotheken zelfs 4 tot $7 \%$-punt. Op computer- en communicatieve vaardigheden blijven daarentegen de assistenten van zelfstandige apotheken enigszins achter. De verschillen zijn echter minimaal.

Regionale verschillen zijn er eveneens nauwelijks. Opvallend is echter wel dat apothekersassistenten in de regio Oost het hoogste gemiddelde scoren op alle competenties. Kijken we naar het percentage onvoldoendes dan zien we eveneens slechts kleine verschillen. Assistenten in de regio Zuidoost scoren vaker een onvoldoende voor hun kennis van ziektebeelden en de manier waarop informatie wordt 
verstrekt, hoewel nog altijd niet meer dan $7 \%$ van de apotheken in deze regio de assistenten voor deze competenties een onvoldoende geeft. Apothekers in de regio Noord geven hun assistenten vaker een onvoldoende voor hun kennis van ziektebeelden en hun computervaardigheden.

Ook tussen grote en kleine apotheken bestaan er nauwelijks verschillen. Voor de omgang met collega's krijgen assistenten in grote apotheken overigens wel wat vaker een onvoldoende dan assistenten in kleinere apotheken. Voor de informatieverstrekking over geneesmiddelen krijgen assistenten in kleine apotheken daarentegen wat vaker een onvoldoende van de apotheker.

Regionale verschillen zijn er eveneens nauwelijks. Opvallend is echter wel dat apothekersassistenten in de regio Oost het hoogste gemiddelde scoren op alle competenties. Kijken we naar het percentage onvoldoendes dan zien we eveneens slechts kleine verschillen. Assistenten in de regio Zuidoost scoren vaker een onvoldoende voor hun kennis van ziektebeelden en de manier waarop informatie wordt verstrekt, hoewel nog altijd niet meer dan $7 \%$ van de apotheken in deze regio de assistenten voor deze competenties een onvoldoende geeft. Apothekers in de regio Noord geven hun assistenten vaker een onvoldoende voor hun kennis van ziektebeelden en hun computervaardigheden.

Ook tussen grote en kleine apotheken bestaan er nauwelijks verschillen. Voor de omgang met collega's krijgen assistenten in grote apotheken overigens wel wat vaker een onvoldoende dan assistenten in kleinere apotheken. Voor de informatieverstrekking over geneesmiddelen krijgen assistenten in kleine apotheken daarentegen wat vaker een onvoldoende van de apotheker.

\section{Veranderingen en competenties}

Het blijkt dat er slechts een klein verschil bestaat tussen de competentiescores van apothekersassistenten die in een apotheek werken waar bepaalde externe of interne veranderingen plaatsvinden en apothekersassistenten die in een apotheek werken waar juist géén veranderingen plaatsvinden. Het algehele competentieniveau van de apothekersassistenten in apotheken waarin veranderingen zijn opgetreden ligt iets hoger (zo'n 0,2 punten) dan in apotheken waarin geen veranderingen plaatsvinden. Dit zou er op kunnen wijzen dat apothekers die bepaalde veranderingen op zich af zien komen wat meer investeren in de competenties van hun assistenten. Het kan echter ook betekenen dat assistenten in veranderingssituaties boven de verwachting van de apotheker presteren. Apothekers die geen veranderingen zien in het werk van de apothekersassistent geven hun assistenten wel een hoger cijfer voor zelfstandigheid dan apothekers die wel veranderingen waarnemen. Mogelijk zijn apothekersassistenten in een stabiele omgeving beter in staat om zelfstandig te werken. De gevonden verschillen zijn echter niet significant.

Apothekers die zien dat de veranderingen in het werk van apothekersassistenten vereisen dat de assistenten meer kennis van geneesmiddelen hebben, beoordelen het competentieniveau van hun assistenten op het gebied van de geneesmiddelen- 
kennis wat lager dan apothekers die een dergelijke verandering niet waarnemen of niet belangrijk vinden. Kennelijk ervaren de apothekers die deze veranderingen op farmaceutisch gebied op zich af zien komen de noodzaak tot bijscholing het sterktst.

$\mathrm{Er}$ is daarentegen nauwelijks verschil tussen de scores voor de communicatieve vaardigheden van assistenten die in een apotheek werkzaam zijn waar veranderingen in de benadering van klanten (mondigheid van cliënten, klantgerichtheid, intensivering van de patiëntenzorg of het verzorgen van spreekuren) plaatsvinden en assistenten die in een apotheek werken waar de apotheker deze veranderingen minder belangrijk vindt. 



\section{Knelpunten op de arbeidsmarkt}

\subsection{Inleiding}

In dit hoofdstuk worden de knelpunten op de arbeidsmarkt voor personeel in de openbare apotheek beschreven. Ook hierbij wordt vooral stilgestaan bij de positie van apothekersassistenten. Daarnaast zal enige aandacht worden besteed aan de vacatures voor de functie van tweede apothekers en voor de andere functies in de openbare apotheek.

De arbeidsmarkt voor apothekersassistenten kan getypeerd worden als een professionele vakdeelmarkt. ${ }^{13}$ Dit houdt in dat er een nauwe aansluiting tussen opleiding en beroep van apothekersassistenten bestaat. Bij een krappe arbeidsmarkt, waarbij er sprake is van een tekort aan apothekersassistenten, zorgt een professionele vakdeelmarkt voor extra problemen. De substitutiemogelijkheden voor werkgevers zijn dan immers beperkt, omdat het niet goed mogelijk is om personeel met een andere opleidingsachtergrond in dienst te nemen. Daarbij komt nog dat op dit moment niet alleen de apothekersbranche, maar de gehele zorgsector met het probleem van krapte op de arbeidsmarkt kampt. De concurrentieslag om het toch al schaarse personeel wordt dus steeds feller.

In dit hoofdstuk staan de knelpunten op de arbeidsmarkt voor apothekersassistenten centraal. Het gaat daarbij om de vacatureproblematiek in de openbare apotheek en om het personeelsverloop onder apothekersassistenten, zoals deze november 2001 werden gemeten. Daarnaast wordt aandacht besteed aan de perspectieven van apothekersassistenten elders op de arbeidsmarkt. Ten slotte komt een belangrijk gevolg van de arbeidsmarktknelpunten aan de orde, namelijk de werkdruk van apothekersassistenten. Hierbij zal steeds nagegaan worden in hoeverre factoren als de soort apotheek, de apotheekgrootte en de regio hierop van invloed zijn.

Allereerst wordt in paragraaf 3.2 beschreven hoeveel vacatures er in de openbare apotheek openstaan. Daarnaast wordt onderzocht hoe lang het duurt voordat ze opgevuld worden, wat de belangrijkste problemen bij het opvullen van deze vacatures zijn, en hoe de vacatures voor apothekersassistenten in de openbare apotheek ontstaan zijn.

In paragraaf 3.3 wordt ingegaan op een tweede aspect van de knelpunten op de arbeidsmarkt voor apothekersassistenten: het personeelsverloop. $\mathrm{Er}$ wordt een balans opgemaakt van het verloop onder apothekersassistenten in de openbare apotheek in het afgelopen jaar: hoeveel apothekersassistenten zijn er aangenomen en hoeveel zijn er vertrokken? Voorts wordt onderzocht wat de belangrijkste redenen van vertrek zijn. Ook worden de verwachtingen van apothekers over het toekomstige personeelsverloop onder apothekersassistenten in kaart gebracht.

13. A. de Grip en J.D. Vlasblom (1999). Toekomstverkenning arbeidsmarkt apothekersassistenten in de openbare apotheek, ROA-R-1999/7, Maastricht. 
In paragraaf 3.4 worden de arbeidsmarktperspectieven van apothekersassistenten in de openbare apotheek onder de loep genomen. Hoe schatten de apothekers de arbeidsmarktperspectieven van apothekersassistenten binnen en buiten de apothekersbranche in?

Ten slotte wordt in paragraaf 3.5 aandacht besteed aan een belangrijk gevolg van de knelpunten op de arbeidsmarkt, namelijk de werkdruk voor apothekersassistenten. Een veel gehoorde klacht is dat de werkdruk in de openbare apotheek toeneemt omdat er met minder mensen toch hetzelfde werk verricht moet worden. Onderzocht wordt hoe apothekers de werkdruk van de bij hen werkzame apothekersassistenten beoordelen en wat volgens hen de belangrijkste gevolgen van deze werkdruk zijn.

\subsection{Vacatures in de openbare apotheek}

De apothekers is gevraagd informatie te verstrekken over het aantal openstaande vacatures binnen hun apotheekvestiging op het moment van ondervraging (november 2001). Tabel 3.1 laat zien dat $43 \%$ van alle openbare apotheken één of meer openstaande vacatures heeft. Het gaat hierbij meestal om een vacature voor de functie van apothekersassistent; vacatures voor een tweede apotheker of voor overige functies binnen de openbare apotheek komen minder vaak voor. Echter, gezien het veel geringere aantal tweede apothekers dat in de openbare apotheek werkzaam is, zijn de knelpunten ook hier groot. Maar liefst 1 op de 9 apotheken heeft een vacature voor een tweede apotheker. Het tekort aan tweede apothekers zal bovendien in de toekomst nog toenemen omdat het aantal studenten farmacie de afgelopen jaren sterk teruggelopen is.

\section{Tabel 3.1}

Openstaande vacatures voor apothekersassistent, tweede apotheker en overige functies in de openbare apotheek, november 2002

\begin{tabular}{lccc}
\hline Functie & $\begin{array}{c}\text { Apotheken met } \\
\text { vacature(s) } \\
\%\end{array}$ & $\begin{array}{c}\text { Gemiddeld aantal } \\
\text { vacatures per apotheek }\end{array}$ & $\begin{array}{c}\text { Gemiddeld aantal } \\
\text { vacatures per apotheek } \\
\text { in FTE }\end{array}$ \\
\hline Apothekersassistent & 37 & 0,48 & 0,40 \\
Tweede apotheker & 12 & 0,11 & 0,08 \\
Andere functies & 6 & 0,06 & 0,04 \\
Totaal & 43 & 0,66 & 0,53
\end{tabular}

Bron: ROA/SFK

Gemiddeld genomen heeft een openbare apotheek 0,66 vacatures open staan. Voor de functie van apothekersassistent bedraagt dit gemiddelde bijna een halve vacature. Aangezien deeltijdwerk binnen de openbare apotheek veelvuldig voorkomt, is het gemiddelde aantal vacatures ook in FTE uitgedrukt. Uit de laatste kolom van tabel 3.1 blijkt dat het gemiddelde aantal vacatures voor apothekersassistenten per apotheek 0,4 FTE bedraagt. Voor de gehele apothekersbranche zou dit uitkomen op een totaal aantal van 850 openstaande vacatures op fulltime basis, waarvan 135 vacatures voor de functie van tweede apotheker en 650 vacatures voor de functie 
van apothekersassistent. ${ }^{14}$ Het aantal vacatures in de openbare apotheek is dus aanzienlijk te noemen.

Figuur 3.1

Vacaturegraad (aantal vacatures voor de functie van apothekersassistent per 1.000 assistenten), naar regio, november 2001

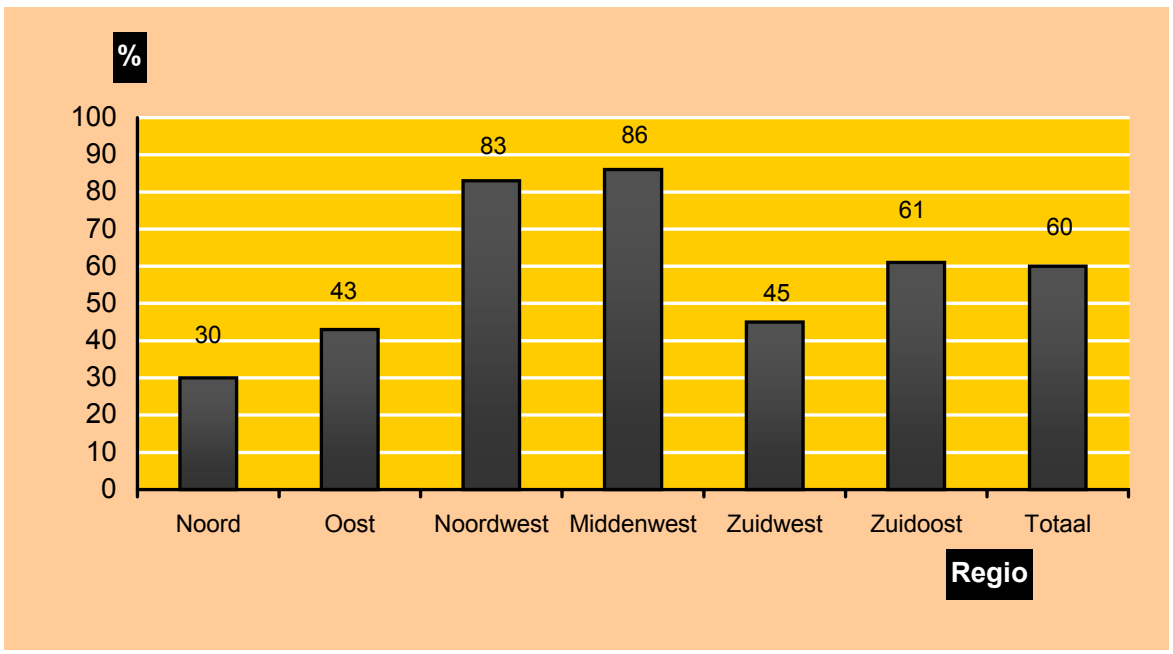

Bron: ROA/SFK

Zijn er verschillen in het aantal vacatures tussen de soort apotheek, de apotheekgrootte en de regio? Om een antwoord op deze vraag te kunnen geven, wordt de vacaturegraad - het aantal vacatures per 1.000 apotheekmedewerkers - berekend. Voor alle functies in de openbare apotheek tezamen zijn er 59 vacatures per 1.000 medewerkers. Wat de functie van apothekersassistent betreft blijken er 60 vacatures per 1.000 assistenten te zijn. Kleine apotheekgroepen lijken wat minder openstaande vacatures te hebben, maar de verschillen zijn erg klein. Apotheken met minder dan 9 medewerkers hebben relatief gezien meer openstaande vacatures, terwijl grote apotheken een beduidend lagere vacaturegraad kennen. Het aantal receptregels dat in een apotheek verwerkt wordt heeft geen significante invloed op de vacaturegraad. De grootste verschillen zijn echter tussen de regio's te vinden. Uit figuur 3.1 blijkt dat met name in de Randstad (de regio's Noordwest en Middenwest) veel vacatures openstaan. Het aantal vacatures voor de functie van apothekersassistent in deze regio's is respectievelijk 83 en 86 per 1.000 assistenten. Ook de regio Zuidoost kent relatief veel openstaande vacatures. De apothekers in de regio Noord hebben

14. Deze cijfers zijn berekend volgens de formule vacatures $=(N / n) \times$ vac, waarbij geldt: vacatures $=$ het totaal aantal vacatures op fulltime basis in een bepaalde beroepsgroep voor de gehele branche;

$N=$ het totaal aantal openbare apotheken in Nederland in 2001;

$n=$ het aantal apotheken in de enquête met informatie over het al of niet hebben van vacatures:

$v a c=$ het totaal aantal vacatures op fulltime basis in een bepaalde beroepsgroep dat door $n$ opgegeven is.

Zo is het totaal aantal vacatures op fulltime basis voor de functie van tweede apotheker in de gehele apothekersbranche gelijk aan $(1629 / 542) \times 45,01=135,28$. Voor de functie van apothekersassistent is dit aantal gelijk aan $(1629 / 524) \times 209,54=651,41$. 
daarentegen de minste knelpunten in hun personeelsvoorziening. Hier staan 30 vacatures voor de functie van apothekersassistent per 1.000 assistenten open.

Duur van de openstaande vacatures

Hoe lang staan deze vacatures in de openbare apotheek open? De onderste rij van tabel 3.2 laat zien dat de vacatures voor apothekersassistenten in de openbare apotheek gemiddeld ongeveer 6 maanden open staan. Vacatures voor tweede apothekers zijn nog moeilijker te vervullen; zij staan gemiddeld zo'n 8 maanden open. Opvallend genoeg worden er geen significante verschillen in de duur van de openstaande vacatures gevonden tussen de diverse soorten apotheken, tussen kleine en grote apotheken en tussen regio's. Vacatures in de regio Noordwest, waar ook een hoge vacaturegraad is, lijken op het eerste gezicht wel wat langer open te staan dan in de andere regio's (gemiddeld zo'n 9 maanden), maar deze verschillen blijken niet significant te zijn.

Tabel 3.2

Gemiddeld aantal maanden dat vacatures in de openbare apotheek openstaan, 2001

\begin{tabular}{lcccc}
\hline & $\begin{array}{c}\text { Apothekersassistent } \\
\text { Tweede }\end{array}$ & $\begin{array}{c}\text { Tweed } \\
\text { Apothek } \\
\%\end{array}$ & $\begin{array}{c}\text { Overige } \\
\text { functies } \\
\%\end{array}$ & Totaal \\
\hline 1-3 maanden & 45 & 26 & 57 & 40 \\
3-6 maanden & 19 & 18 & 10 & 19 \\
6-12 maanden & 21 & 25 & 20 & 25 \\
Meer dan 12 maanden & 16 & 32 & 13 & 17 \\
Gemiddeld aantal maanden & 5,8 & 8,1 & 4,5 & 6,1 \\
\hline Bron: ROASFK & & & &
\end{tabular}

Bron: ROA/SFK

Kijken we nog wat nader naar deze vacatures, dan blijkt dat $40 \%$ korter dan 3 maanden openstaat. Deze vacatures blijken dus redelijk snel vervuld te kunnen worden. Toch moet het merendeel van de vacatures volgens de gangbare maatstaven als moeilijk vervulbaar getypeerd worden. Zo staat één op de vijf vacatures (125 FTE) voor apothekersassistenten 3 tot 6 maanden open, en eenzelfde aantal maar liefst 6 tot 12 maanden. Voor $16 \%$ van de vacatures (105 FTE) duurt het zelfs meer dan een jaar voordat er een nieuwe apothekersassistent aangenomen wordt. De knelpunten in de personeelsvoorziening van tweede apothekers zijn zoals gezegd nog groter. Maar liefst een kwart van de vacatures (35 FTE) voor tweede apothekers staat 6 tot 12 maanden open, en voor één op de drie vacatures (45 FTE) duurt het meer dan een jaar voordat ze vervult zijn.

De reden voor het moeilijk opvullen van vacatures voor apothekersassistenten in de openbare apotheek moet volgens tabel 3.3 overduidelijk gezocht worden in het tekort schieten van het aanbod van personeel. Maar liefst $81 \%$ van de apothekers geeft aan hierdoor problemen te hebben met het opvullen van vacatures. Daarna volgen te hoge salariseisen en andere eisen (beide ongeveer 10\%), een gebrekkige aansluiting van de opleiding $(7 \%)$ en te weinig ervaring $(6 \%)$ van sollicitanten. $21 \%$ Van de 
apothekers noemt een ander probleem, waaronder de werktijden, de geringe carrièreperspectieven van de apothekersassistenten, het imago van het beroep en de werkdruk in de openbare apotheek.

Tabel 3.3

Belangrijkste problemen bij het opvullen van vacatures voor apothekersassistenten in de openbare apotheek, november 2001

\begin{tabular}{lcc}
\hline Probleem & $\%$ \\
\hline Te weinig aanbod van personeel & 81 & \\
Te hoge salariseisen & 11 & \\
Te hoge andere eisen & 10 & \\
Gebrekkige aansluiting van de opleiding & 7 & \\
Onvoldoende ervaring personeel & 6 & \\
Overig, waaronder & 21 & 3 \\
Werktijden & & 2 \\
Carrièreperspectieven & 2 \\
Imago van het beroep & & 2 \\
Werkdruk & &
\end{tabular}

$\overline{\text { Noot: aangezien een apotheker meerdere problemen kon noemen, tellen deze percentages niet }}$ op tot $100 \%$.

Bron: ROA/SFK

Overigens geeft $14 \%$ van de apothekers aan geen problemen te hebben met het opvullen van vacatures voor apothekersassistenten. In de regio's Noord, Oost en Zuidwest ondervindt een groter deel van de apothekers (ongeveer 20\%) geen problemen. De vacaturegraad is in deze regio's ook het laagst. Apothekers in deze drie regio's melden ook beduidend minder vaak problemen met het aanbod van personeel. Ten slotte hebben in de regio Middenwest meer apothekers (18\%) problemen met de te hoge eisen van de sollicitanten dan in de andere regio's.

\section{Oorzaak vacatures voor apothekersassistenten}

Naast het onderzoeken van de problemen bij het opvullen van de vacatures voor apothekersassistenten is het van belang om de oorzaak achter deze vacatures te achterhalen. Zijn de vacatures ontstaan vanuit een vervangingsvraag, dat wil zeggen is er sprake van vertrek van personeel dat vervangen moet worden? Of heeft het aantal vacatures te maken met een toename in de hoeveelheid werk? Aan de apothekers is gevraagd aan te geven hoe de openstaande vacatures voor apothekersassistenten ontstaan zijn. Uit figuur 3.2 blijkt dat apothekers voornamelijk het vertrek van personeel als oorzaak van hun vacatures noemen $(37 \%)$. De toename van de hoeveelheid werk is voor $19 \%$ van de apothekers een oorzaak voor het ontstaan van vacatures voor apothekersassistenten. Opvallend is dat een deel van de vacatures ontstaat omdat apothekersassistenten minder zijn gaan werken (21\%). Zo blijkt uit cijfers van de SFK dat met name apothekersassistenten boven de dertig de voorkeur geven aan een kortere werkweek: $70 \%$ van hen werkt 3 dagen of min- 
der. ${ }^{15}$ Daarnaast ontstaat $14 \%$ van de vacatures voor apothekersassistenten omdat zij tijdelijk niet inzetbaar zijn. In het laatste geval gaat het met name om assistenten die met zwangerschapsverlof zijn (6\%) of die ziek zijn (7\%). Er kan dan ook geconcludeerd worden dat het merendeel van de vacatures voor apothekersassistenten ontstaan is vanuit een vervangingsvraag. Uitbreiding in de zin van een toename in de hoeveelheid werk in de openbare apotheek ligt veel minder vaak ten grondslag aan het ontstaan van vacatures.

Figuur 3.2

Oorzaken van het ontstaan van vacatures voor apothekersassistenten in de openbare apotheek, 2001

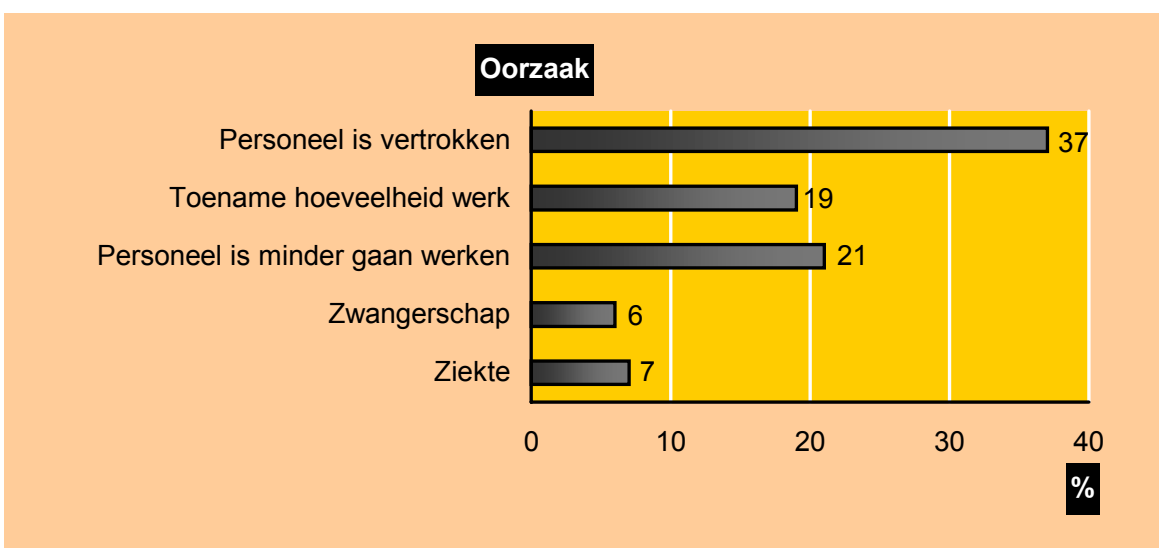

Bron: ROA/SFK

De oorzaken voor het ontstaan van vacatures voor apothekersassistenten zijn hetzelfde voor zelfstandige apotheken, apotheken in kleine apotheekgroepen en apotheken in grote apotheekgroepen. Ook zijn er geen grote verschillen tussen kleine en grote apotheken waar te nemen. Wel is het zo dat apotheken met minder dan 80.000 receptregels minder vaak een toename in de hoeveelheid werk als reden voor het ontstaan van vacatures noemen. Deze uitbreidingsvraag speelt een veel grotere rol bij apotheken met meer verwerkte receptregels. De regionale verschillen in de oorzaken van de ontstane vacatures zijn eveneens erg klein, op één uitzondering na. De apotheken in de twee regio's met de hoogste vacaturegraad, namelijk Noordwest en Middenwest, hebben vaker te maken met personeel dat vertrokken is dan de apotheken in de andere regio's. Maar liefst de helft van de apotheken in de regio's Noord- of Middenwest noemt het personeelsverloop als oorzaak voor het ontstaan van vacatures voor apothekersassistenten. In de volgende paragraaf gaan we nader op dit personeelsverloop in.

\subsection{Personeelsverloop in de openbare apotheek}

Een tweede (mogelijk) arbeidsmarktknelpunt is het grote personeelsverloop onder

15. Zie: SFK-publicatie Farmacie in Cijfers "Hoge werkdruk in apotheken" Pharmaceutisch Weekblad, jaargang 137, nr 18. 
apothekersassistenten in de openbare apotheek. In figuur 3.3 is dit personeelsverloop in kaart gebracht voor de periode november 2000 tot november 2001 (de 12 maanden voorafgaand aan het tijdstip van ondervraging). De figuur laat zien dat $57 \%$ van de apotheken in deze periode één of meerdere nieuwe apothekersassistenten heeft aangetrokken, terwijl $63 \%$ van de apotheken één of meerdere apothekersassistenten zag vertrekken. Voor de gehele apothekersbranche betekent dit dat er ongeveer 1.380 nieuwe apothekersassistenten zijn ingestroomd, hetgeen neerkomt op bijna 1.050 FTE. Het aantal uitgestroomde apothekersassistenten bedraagt ruim $1.850 .^{16}$

Figuur 3.3

Aantal uit- en ingestroomde apothekersassistenten per apotheek, 2001

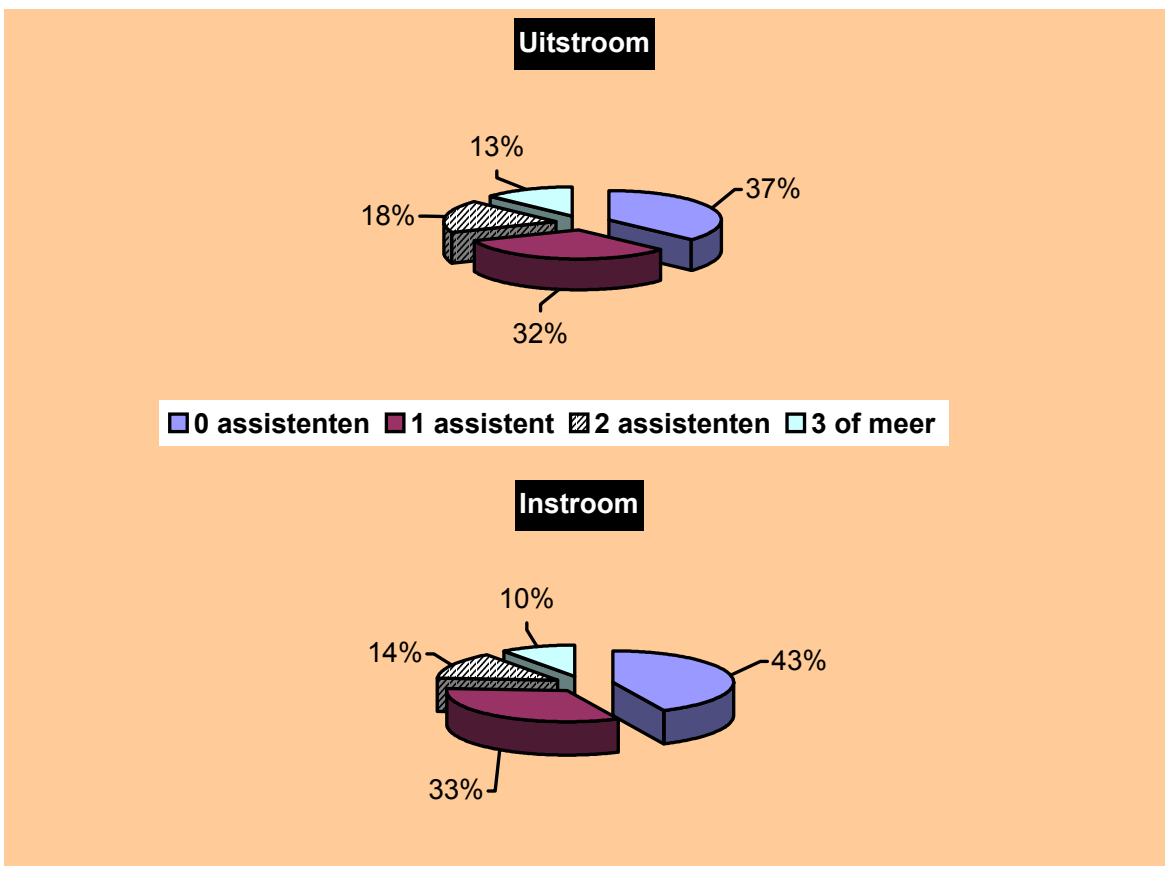

Bron: ROA/SFK

Tabel 3.4 laat zien dat $11 \%$ van de werkzame apothekersassistenten het afgelopen jaar nieuw is ingestroomd. Tegenover deze instroom staat een personeelsuitstroom van $14 \%$. De verschillen in in- en uitstroom van apothekersassistenten tussen de diverse soorten apotheken zijn niet significant. Ook de grootte van de apotheek

16. Voor het aantal uitgestroomde apothekersassistenten zijn geen cijfers over het aantal FTE beschikbaar. De cijfers zijn berekend volgens de formule: aantal $=(N / n) \times S$, waarbij geldt: aantal = het totaal aantal in- of uitgestroomde apothekersassistenten voor de gehele apothekersbranche;

$N=$ het totaal aantal openbare apotheken in Nederland in 2001;

$n=$ het aantal apotheken in de enquête met informatie over in- en uitgestroomde apothekersassistenten;

$S=$ het totaal aantal in- of uitgestroomde apothekersassistenten dat door $n$ opgegeven is. Zo is het totaal aantal ingestroomde apothekersassistenten voor de gehele apothekersbranche gelijk aan (1.629/549) x $466=1.383$, en het aantal uitgestroomde apothekersassistenten $(1.629 / 531) \times 605=1.856$. 
beïnvloedt de in- en uitstroomgraad niet erg. De uitstroom van apothekersassistenten lijkt wat groter voor de kleine apotheken, maar dit verschil is niet significant.

Wel is er sprake van regionale verschillen in in- en uitstroom. De regio 's Oost en Zuidoost kennen een vrij kleine instroom, maar in deze twee regio's is ook de uitstroom van apothekersassistenten niet bijzonder groot. In deze regio's lijkt de mobiliteit van de apothekersassistenten dus op een relatief laag niveau te liggen. De regio Noord kenmerkt zich daarentegen door een uitzonderlijk hoge instroom van $19 \%$. Aangezien in deze regio ook veel apothekersassistenten uitstromen, is het personeelsverloop hoog te noemen, maar levert dit geen grote problemen op. Al eerder zagen we dat het aantal openstaande vacatures in de regio Noord laag is. De knelpunten op de arbeidsmarkt zijn hier dus niet erg groot. Zorgwekkender is de toestand in de Randstad (de regio's Noordwest en Middenwest). Mede als gevolg van de krapte op de arbeidsmarkt, is er in deze regio's sprake van een hoog personeelsverloop, met name in de regio Noordwest. Wanneer deze uitstroom geleid heeft tot een vraag naar nieuw personeel, dan is men er niet in geslaagd aan deze vervangingsvraag te voldoen. Het uitstroompercentage is in deze regio's immers beduidend hoger dan het instroompercentage. In de vorige paragraaf zagen we al dat deze twee regio's ook de meeste openstaande vacatures kennen.

Tabel 3.4

Instroom- en uitstroompercentage voor apothekersassistenten in de openbare apotheek, naar soort apotheek, regio en omvang, 2001

\begin{tabular}{lcc}
\hline & $\begin{array}{c}\text { Instroom } \\
\%\end{array}$ & $\begin{array}{c}\text { Uitstroom } \\
\%\end{array}$ \\
\hline Soort apotheek & & 14 \\
Zelfstandige apotheek & 10 & 14 \\
Kleine apotheekgroep van minder dan 5 apotheken & 15 & 13 \\
Grote apotheekgroep van 5 of meer apotheken & 12 & \\
Regio & & 15 \\
Noord & 19 & 20 \\
Oost & 10 & 18 \\
Noordwest & 11 & 11 \\
Middenwest & 12 & \\
Zuidwest & 11 & 13 \\
Zuidoost & 10 & 16 \\
Omvang & & 12 \\
Klein (0-60.000 receptregels) & 14 & 14 \\
Middelgroot (60.000-80.000 receptregels) & 10 & \\
Groot (80.000-100.000 receptregels) & 11 & \\
Zeer groot (100.000 en meer receptregels) & 10 & \\
Totaal & 11 & \\
& & \\
\hline
\end{tabular}

Bron: ROA/SFK

Reden van uitstroom apothekersassistenten

Aan de apothekers die in de periode november 2000 tot november 2001 apothekersassistenten uit hun apotheek zagen vertrekken is gevraagd de voornaamste redenen van deze uitstroom aan te geven. Figuur 3.4 laat zien dat apothekers een te lange 
reistijd $(22 \%)$ en een verhuizing van de apothekersassistent $(18 \%)$ het vaakst als oorzaak noemen. Dit duidt erop dat apothekersassistenten graag dichtbij hun werk willen wonen. Daarnaast spelen de werksfeer en het niet bevredigend zijn van het soort werk volgens de apothekers een belangrijke rol bij het vertrek van apothekersassistenten (beide 18\%), gevolgd door de betere carrièreperspectieven van apothekersassistenten buiten de branche (16\%) en elders in de branche (14\%). Ook een te hoge werkdruk is een belangrijke uitstroomreden (13\%). Deze reden wordt opvallend vaak genoemd door apothekers in de regio's Noord en Noordwest, en beduidend minder vaak in de regio's Middenwest, Zuidwest en Zuidoost. In paragraaf 3.5 zal hier nader op ingegaan worden. Ten slotte is de keuze voor zorgtaken een belangrijke reden voor het verloop van apothekersassistenten $(11 \%)$, terwijl gezondheidsproblemen door $9 \%$ van de apothekers als reden van uitstroom genoemd wordt. Gezondheidsproblemen spelen overigens veel vaker een rol bij de uitstroom van apothekersassistenten in middelgrote en grote apotheken.

\section{Figuur 3.4}

Belangrijkste redenen voor vertrek van apothekersassistenten in de openbare apotheek, 2001

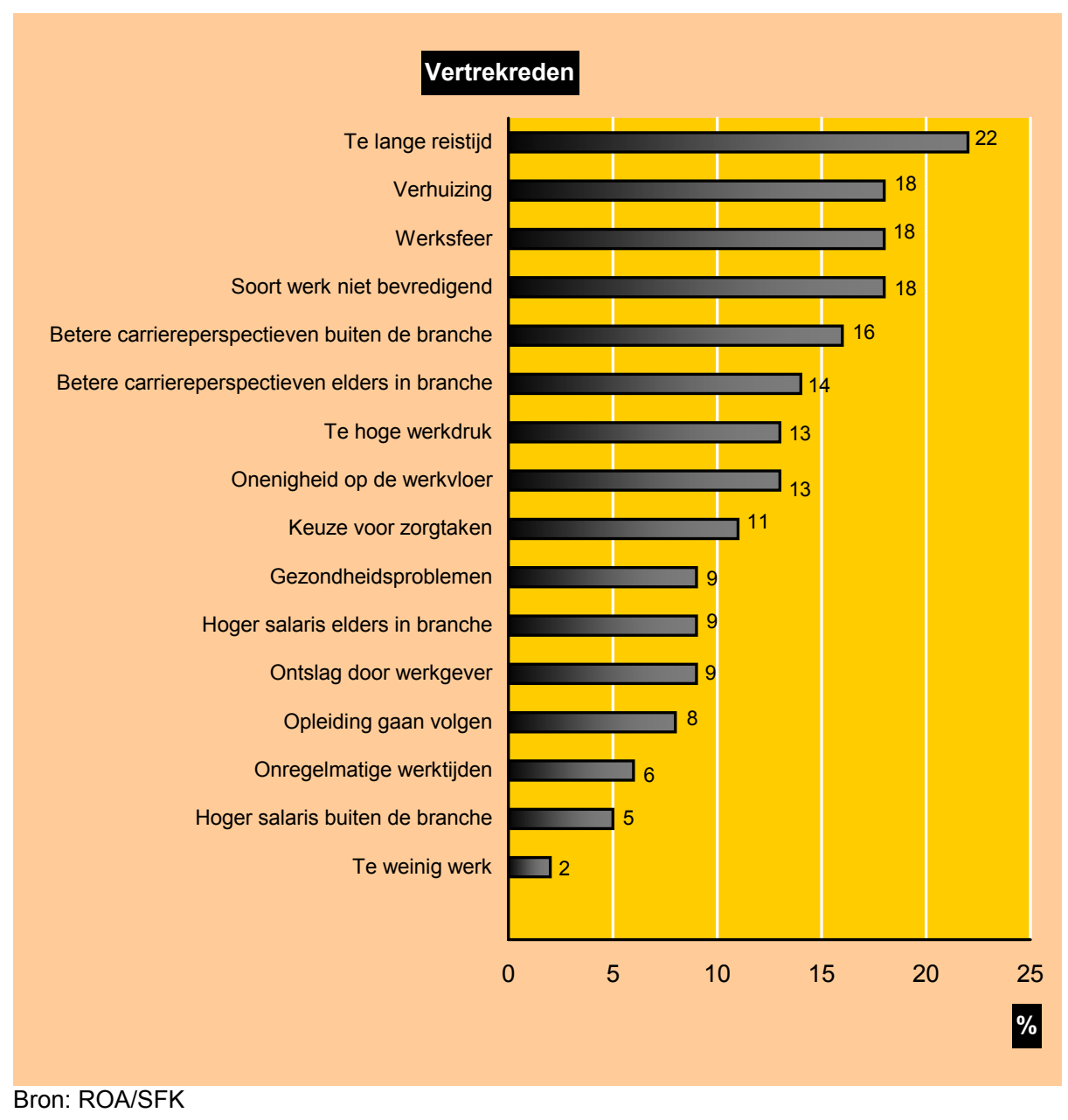




\section{Toekomstverwachtingen personeelsverloop}

Al met al kunnen we uit de gepresenteerde cijfers concluderen dat het personeelsverloop onder apothekersassistenten vrij hoog is. De laatste kolom in tabel 3.5 laat zien dat $60 \%$ van de apothekers verwacht dat dit personeelsverloop de komende 2 jaar gelijk zal blijven. Er zijn echter meer apothekers die een toename van het personeelsverloop verwachten $(28 \%)$, dan apothekers die verwachten dat het verloop zal afnemen (12\%). Dit duidt op nog grotere problemen in de personeelsvoorziening voor veel apothekers in de toekomst.

Tabel 3.5

Toekomstverwachtingen over het personeelsverloop onder apothekersassistenten in de openbare apotheek, naar regio, 2001

\begin{tabular}{lccccccc}
\hline Verloop & Noord & Oost & $\begin{array}{c}\text { Noord- } \\
\text { west } \\
\%\end{array}$ & $\begin{array}{c}\text { Midden- } \\
\text { west } \\
\%\end{array}$ & $\begin{array}{c}\text { Zuid- } \\
\text { west } \\
\%\end{array}$ & $\begin{array}{c}\text { Zuid- } \\
\text { oost } \\
\%\end{array}$ & $\begin{array}{c}\text { Totaal } \\
\%\end{array}$ \\
\hline Neemt toe & 24 & 23 & 31 & 30 & 23 & 37 & 28 \\
Blijft gelijk & 64 & 68 & 52 & 59 & 68 & 51 & 60 \\
Neemt af & 12 & 8 & 17 & 12 & 9 & 12 & 12 \\
\hline
\end{tabular}

Bron: ROA/SFK

Tabel 3.5 laat ook de verschillen tussen de regio's zien. Zo verwachten apothekers in de regio Zuidoost wat vaker dat het personeelsverloop de komende 2 jaar zal toenemen dan apothekers in de overige regio's. Apothekers in de regio Noordwest verwachten daarentegen wat vaker dat het personeelsverloop zal afnemen. Overigens geeft $36 \%$ van alle apothekers die een afname van het personeelsverloop verwacht als reden op dat het verloop in het afgelopen jaar al zo hoog was, dat het alleen nog maar kan afnemen.

Tabel 3.6

Belangrijkste oorzaken voor de verwachte toename in het personeelsverloop van apothekersassistenten in de openbare apotheek, 2001

Oorzaak voor toename verloop $\quad \%$

Zorgtaken apothekersassistenten $\quad 33$

Deeltijdwerk apothekersassistenten 16

Pensioen apothekersassistenten 14

Werkdruk apothekersassistenten 13

Uitbreiding van de apotheek 12

Concurrentie van andere apotheken

Veranderingen in werk 4

Verhuizing apothekersassistenten 4

Opleiding apothekersassistenten

Bron: ROA/SFK

Als belangrijkste oorzaak voor de verwachte toename in het personeelsverloop wijzen de apothekers aan dat meer apothekersassistenten in hun apotheek de komende 2 jaar voor zorgtaken zullen kiezen (zie tabel 3.6). Ook het feit dat meer 
apothekersassistenten in deeltijd willen gaan werken of met pensioen gaan zal tot een groter personeelsverloop leiden. Ten slotte wordt de werkdruk van apothekersassistenten vaak als reden voor de verwachte toename van het personeelsverloop genoemd. Wat dit betreft is er sprake van een vicieuze cirkel: een hogere werkdruk leidt tot meer personeelsverloop, hetgeen weer voor een hogere werkdruk bij het zittende personeel zorgt.

\subsection{Arbeidsmarktperspectieven van apothekersassistenten}

Gezien het grote tekort aan apothekersassistenten dat zich op dit moment voordoet binnen de apothekersbranche en ook daarbuiten zullen apothekersassistenten waarschijnlijk weinig problemen hebben met het vinden van een minstens even aantrekkelijke baan elders binnen of buiten de branche.

Tabel 3.7

Percentage apothekers dat de arbeidsmarktperspectieven van apothekersassistenten in de openbare apotheek als (zeer) gemakkelijk inschat, naar soort apotheek, regio en omvang, 2001

\begin{tabular}{lcc}
\hline & $\begin{array}{c}\text { Binnen de } \\
\text { branche } \\
\%\end{array}$ & $\begin{array}{c}\text { Buiten de } \\
\text { branche } \\
\%\end{array}$ \\
& & \\
\hline Soort apotheek & 65 & 30 \\
Zelfstandige apotheek & 67 & 31 \\
Kleine apotheekgroep van minder dan 5 apotheken & 65 & 38 \\
Grote apotheekgroep van 5 of meer apotheken & & \\
Regio & & 20 \\
Noord & 63 & 19 \\
Oost & 56 & 35 \\
Noordwest & 66 & 37 \\
Middenwest & 71 & 40 \\
Zuidwest & 62 & 30 \\
Zuidoost & 70 & 35 \\
Omvang & & 30 \\
Klein (0-60.000 receptregels) & & 34 \\
Middelgroot (60.000-80.000 receptregels) & 76 & 27 \\
Groot (80.000-100.000 receptregels) & 61 & 31 \\
Zeer groot (100.000 en meer receptregels) & 64 & 62 \\
Totaal & 65 & \\
\hline Bron: ROA/SFK & &
\end{tabular}

Bron: ROA/SFK

Tabel 3.7 laat zien dat volgens $65 \%$ van de apothekers het gemakkelijk tot zeer gemakkelijk voor apothekersassistenten is om elders binnen de branche een minstens even aantrekkelijke baan te vinden. Buiten de branche een minstens even aantrekkelijke functie vinden is volgens de apothekers een stuk moeilijker. Hiervan zegt slechts $31 \%$ dat het (zeer) gemakkelijk zal zijn.

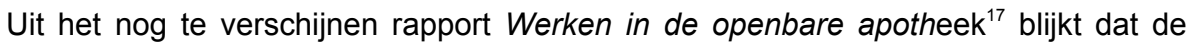
apothekersassistenten zelf hun perspectieven buiten de branche iets minder roos-

17. Zie: A. De Grip en I.J.P. Sieben (2002). Werken in de openbare apotheek, ROA-R-2002, Maastricht. 
kleurig inschatten. Niet meer dan $21 \%$ van de apothekersassistenten denkt dat het (zeer) gemakkelijk is om een even aantrekkelijke baan buiten de apothekersbranche te vinden. Voor een baan binnen de branche ligt dit percentage op 62\%. Dit wijst er op dat apothekersassistenten toch nog wat meer hechting hebben aan hun beroep dan apothekers denken.

Voor de inschatting van het arbeidsmarktperspectief binnen de branche maakt het geen verschil of het zelfstandige apotheken of apotheekgroepen betreft. In de apotheken die tot een grote apotheekgroep behoren, schat men de perspectieven voor apothekersassistenten die buiten de branche aan de slag zouden willen wel wat rooskleuriger in dan in andere apotheken, maar deze verschillen zijn niet significant.

Ook de verschillen tussen kleine en grote apotheken zijn erg klein. Ten slotte worden de arbeidsmarktperspectieven voor apothekersassistenten binnen de branche in alle regio's ongeveer hetzelfde ingeschat. De perspectieven buiten de branche zijn volgens de apothekers echter duidelijk gunstiger voor apothekersassistenten in de regio's Zuidwest en Middenwest. De apothekers in de regio Oost en de regio Noord zien meer moeilijkheden voor apothekersassistenten om buiten de branche aan even aantrekkelijk werk te komen.

\subsection{Werkdruk van apothekersassistenten}

Een belangrijk gevolg van de besproken arbeidsmarktknelpunten zou kunnen zijn dat de werkdruk van apothekersassistenten in de openbare apotheek hoger wordt. Wanneer openstaande vacatures niet opgevuld worden, zullen de zittende apothekersassistenten meestal extra werk moeten verzetten om toch alles af te krijgen. Dit kan ertoe leiden dat apothekersassistenten een hogere werkdruk ervaren.

Aan de apothekers is gevraagd om de werkdruk van de bij hen werkzame apothekersassistenten op een schaal van 1 tot 10 uit te drukken. Figuur 3.5 geeft aan dat apothekers de werkdruk van apothekersassistenten in de openbare apotheek als vrij hoog inschatten. Maar liefst $25 \%$ van de apothekers beoordeelt de werkdruk als hoog (score 8 of meer).

Tussen de verschillende soorten apotheken zijn geen verschillen in de inschatting van de werkdruk voor apothekersassistenten te vinden. De werkdruk lijkt wat hoger in de regio Noordwest, maar ook de regionale verschillen zijn niet significant. Wel beïnvloedt de omvang van de apotheek de werkdruk van de apothekersassistenten.

Uit tabel 3.8 blijkt dat de werkdruk in apotheken met minder dan 80.000 verwerkte receptregels als minder hoog ervaren wordt dan in apotheken met meer verwerkte receptregels. In ongeveer één op de vijf kleinere apotheken is de werkdruk hoog te noemen, tegenover één op de drie grotere apotheken. Ook in apotheken met meer medewerkers is de werkdruk hoger. 
Figuur 3.5

Beoordeling werkdruk van apothekersassistenten in de openbare apotheek, 2001

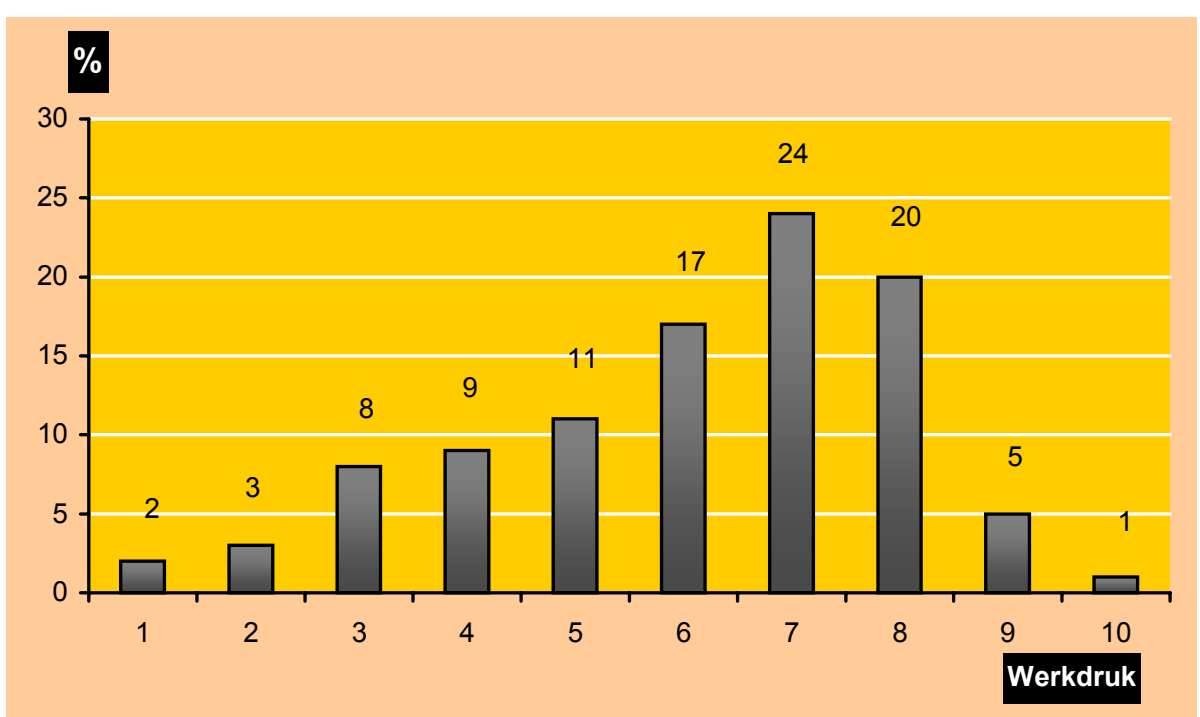

Bron: ROA/SFK

Tabel 3.8

Beoordeling werkdruk van apothekersassistenten in de openbare apotheek, naar omvang apotheek, 2001

\begin{tabular}{lccccc}
\hline & $\begin{array}{c}\text { Klein } \\
\%\end{array}$ & $\begin{array}{c}\text { Middelgroot } \\
\%\end{array}$ & $\begin{array}{c}\text { Groot } \\
\%\end{array}$ & $\begin{array}{c}\text { Zeer groot } \\
\%\end{array}$ & $\begin{array}{c}\text { Totaal } \\
\%\end{array}$ \\
\hline Laag (score 1-3) & 17 & 14 & 10 & 9 & 13 \\
Midden (score 4-7) & 64 & 66 & 57 & 61 & 62 \\
Hoog (score 8-10) & 19 & 20 & 33 & 30 & 25 \\
\hline
\end{tabular}

Bron: ROA/SFK

\section{Gevolgen van werkdruk}

De apothekers hebben kunnen aangeven wat zij denken dat de belangrijkste gevolgen van de hoge werkdruk zijn. In figuur 3.6 worden deze gevolgen op een rijtje gezet. Personeelsverloop wordt het meest genoemd (22\%), gevolgd door geen tijd hebben voor extra taken (17\%). Ook ziekteverzuim (15\%), een slechtere werksfeer $(12 \%)$ en stress $(10 \%)$ worden als belangrijke gevolgen van een hoge werkdruk gezien. Zonder uitzondering zijn dit gevolgen die het belang aangeven van de noodzaak de werkdruk voor apothekersassistenten beheersbaar te houden. 
Figuur 3.6

Belangrijkste gevolgen van de hoge werkdruk onder apothekersassistenten in de openbare apotheek, 2001

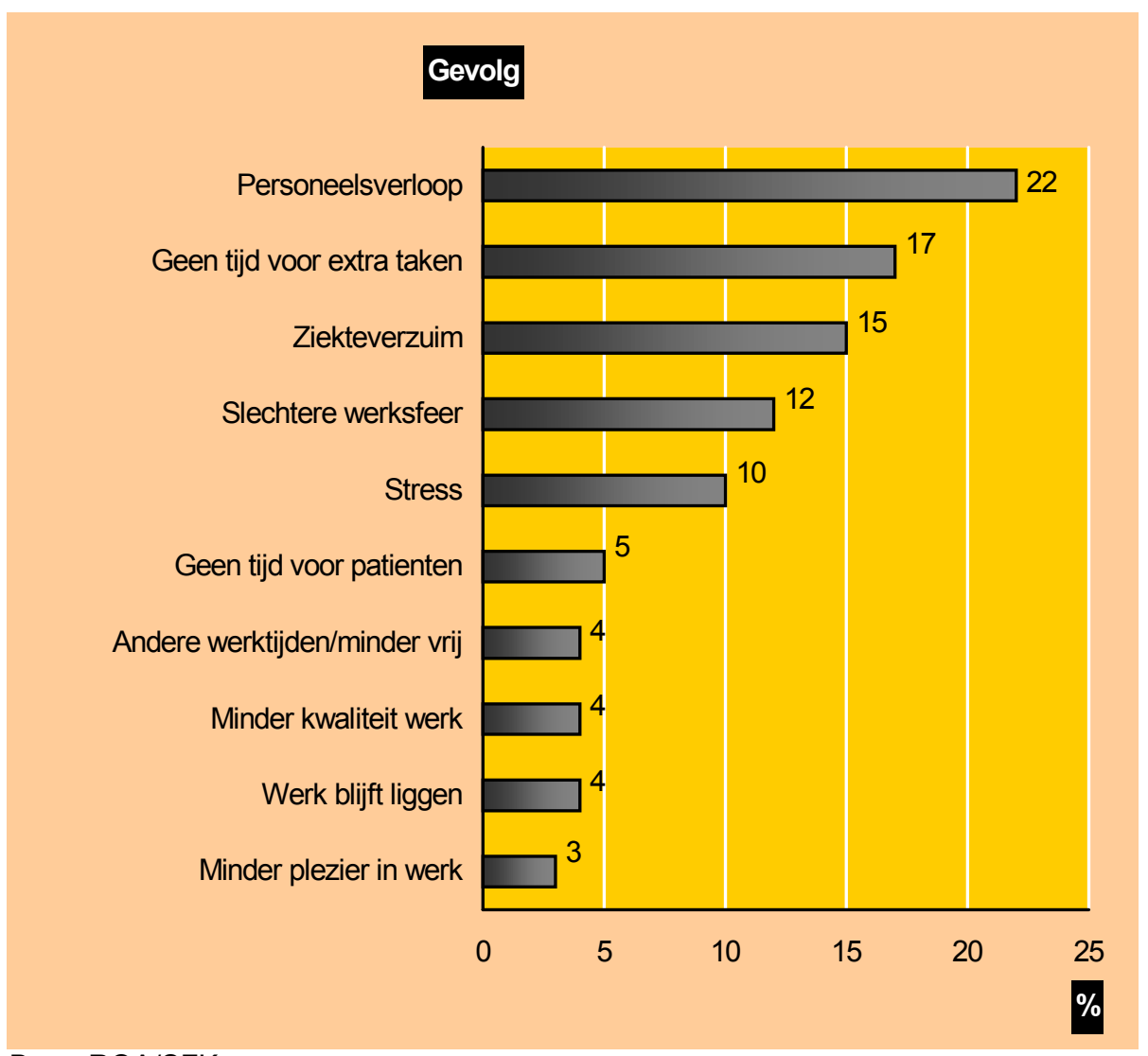

Bron: ROA/SFK 


\section{HRM Beleid}

Apotheken worden geconfronteerd met sterke veranderingen in hun omgeving, waarop zij moeten inspelen. Zoals in paragraaf 2.2. werd aangegeven gaat het daarbij vaak om ingrijpende veranderingen die het nodige eisen van de mensen die in de apotheken werkzaam zijn. De veranderingen die zich voordoen vragen ook om een grote mate van flexibiliteit, zowel van de apotheker als van de assistenten. Vanwege het toenemende deeltijdwerk en de verruiming van de openingstijden van apotheken is het bijvoorbeeld noodzakelijk dat, zeker nu er sprake is van een tekort aan apothekersassistenten, de apothekersassistenten die er zijn, optimaal kunnen worden ingezet. De grote veranderingen in de apothekersbranche en de toename van de knelpunten in de personeelsvoorziening vragen om een goed doordacht beleid dat met name gericht moet zijn op het op peil houden van de aanwezige kennis en vaardigheden binnen de branche en het uitbreiden van het beschikbare 'menselijke kapitaal' door middel van een goed doordachte arbeidsmarktstrategie. Deze elementen komen samen in wat algemeen bekend staat als het Human Resource Management (HRM): personeelsbeleid gericht op het optimaliseren van de inzet van de medewerkers.

In het HRM wordt de ontwikkeling van het menselijke potentieel dat van strategische waarde is voor de overlevingskansen van een organisatie centraal gesteld. Net als alle andere werkgevers staat ook de apotheker een groot aantal instrumenten en maatregelen ter beschikking om het HRM beleid optimaal in te richten en daarmee de effectiviteit van de organisatie te vergroten en de knelpunten in de personeelsvoorziening zoveel mogelijk te beperken. We onderscheiden hierbij vier facetten van het HRM beleid binnen de apothekersbranche.

- Werving en selectie;

- Human Resource Development in de vorm van training en ontwikkeling;

- Kwalitatieve en kwantitatieve inzetbaarheid;

- Arbeidsvoorwaardenbeleid.

In dit hoofdstuk wordt een beeld gegeven van de inspanningen die apothekers op deze vier gebieden doen om goed personeel "te vinden, te binden en te boeien".

\subsection{Werving en selectie}

Het beleid rondom werving en selectie staat aan de basis van het HRM beleid binnen de apotheek. Een goed doordacht wervings- en selectiebeleid zorgt er immers voor dat de juiste werknemers worden binnengehaald en hoe beter het menselijke potentieel dat wordt aangetrokken, des te gemakkelijker en efficiënter is het om dit potentieel te ontwikkelen. Het is echter, zoals gezegd, voor de apotheker zeker niet gemakkelijk om voldoende, laat staan naar de zienswijze van apothekers, optimaal gekwalificeerde, apothekersassistenten aan te trekken. Daarvoor is, zo bleek al eerder in dit rapport, het aanbod te beperkt (zie tabel 3.3). 
Dit betekent dat apothekers nogal eens voor een belangrijke keuze kunnen komen te staan: niemand aannemen of assistenten aannemen die eigenlijk (nog) niet optimaal voldoen aan het gestelde profiel. Apothekers zullen dus creatief moeten zijn in hun benadering van de arbeidsmarkt, om zo de inzet van medewerkers te optimaliseren. De apotheker kan in dat kader een aantal maatregelen doorvoeren. Hij (of zij) kan bijvoorbeeld het werken in zijn apotheek voor potentiële assistenten aantrekkelijker maken door salaris of andere arbeidsvoorwaarden aan te bieden die boven de in de CAO vastgestelde normen uitstijgen. De apotheker kan er echter ook voor kiezen ander personeel (bijvoorbeeld apotheekhulpen) in te zetten, of onderdelen van het werk uit te besteden aan andere apotheken of bedrijven, zodat minder nieuwe assistenten nodig zijn. In deze paragraaf wordt ingegaan op de maatregelen die de apotheken treffen om in hun behoefte aan apothekersassistenten te voorzien.

Figuur 4.1 laat zien dat ruim $12 \%$ van de apothekers, ondanks hun problemen met het vervullen van vacatures, toch geen maatregelen treft om alsnog te voorzien in de vacatures. Zelfstandige apotheken spelen wat minder actief in op hun vacatureproblematiek dan apotheken die tot een groep behoren. De verschillen zijn echter gering.

lets groter zijn de regionale verschillen. In de regio Middenwest treft bijna 10\% van de apotheken geen maatregelen. In de regio Zuidoost laat zo'n 18\% van de apothekers die problemen hebben met het vervullen van hun vacatures maatregelen achterwege. Een belangrijke verklaring voor het gevonden verschil is dat juist de regio Middenwest de hoogste vacaturegraad heeft. Apotheken in de regio Zuidoost hebben wat dat betreft minder te maken met concurrentie om het beschikbare aanbod op de arbeidsmarkt. Veel apothekers in de regio Zuidoost verwachten overigens wel dat de problemen de komende twee jaar zullen toenemen, zo blijkt ook uit tabel 3.5 eerder in dit rapport.

Kijken we naar de omvang van de apotheek, dan blijkt dat kleine en middelgrote apotheken minder maatregelen treffen dan (erg) grote apotheken. Mogelijk zijn de middelen om maatregelen te treffen in de kleine en middelgrote apotheken minder ruim voorhanden. Ook hebben apotheken die wat kleiner in omvang zijn relatief weinig vacatures openstaan. Verstrekkende maatregelen lijken daarom voor de kleinere apotheken vooralsnog wat minder noodzakelijk.

Figuur 4.1 laat ook zien dat de helft van de apotheken die problemen hebben met het invullen van hun vacatures mensen met een andere opleiding aantrekt om hen vervolgens zelf om te scholen tot apothekersassistent. Deze apothekersassistenten in opleiding kunnen hun diploma en daarmee toegang tot hun titel overigens alleen via een erkend opleidingsinstituut behalen. Vooral apotheken die deel uitmaken van kleinere apotheekgroepen gaan hier vaak toe over. Ook leiden vacatureproblemen nogal eens tot het actiever benaderen van scholieren, het uitbesteden van werkzaamheden en het bieden van betere arbeidsvoorwaarden. Het benaderen van arbeidsongeschikten gebeurt daarentegen nagenoeg niet. Het verlagen van opleidings- en ervaringseisen aan apothekersassistenten wordt eveneens nauwelijks overwogen. 
In apotheken die deel uitmaken van een grote apotheekgroep komt het omscholen van anders opgeleiden wat minder vaak voor dan in andere apotheken. In grote apotheekgroepen wordt daarentegen wat vaker een commercieel wervingsbureau ingeschakeld en is er meer aandacht voor het uitbesteden van werk. Zelfstandige apotheken kiezen er daarentegen vaker voor een hoger salaris te bieden of andere, CAO overstijgende, aanpassingen in de arbeidsvoorwaarden te doen. Ook het inschakelen van het arbeidsbureau is een maatregel die door zelfstandige apotheken wat vaker wordt toegepast dan door apotheekgroepen.

Figuur 4.1

Maatregelen van apothekers die problemen hebben hun vacatures op te vullen, 2001

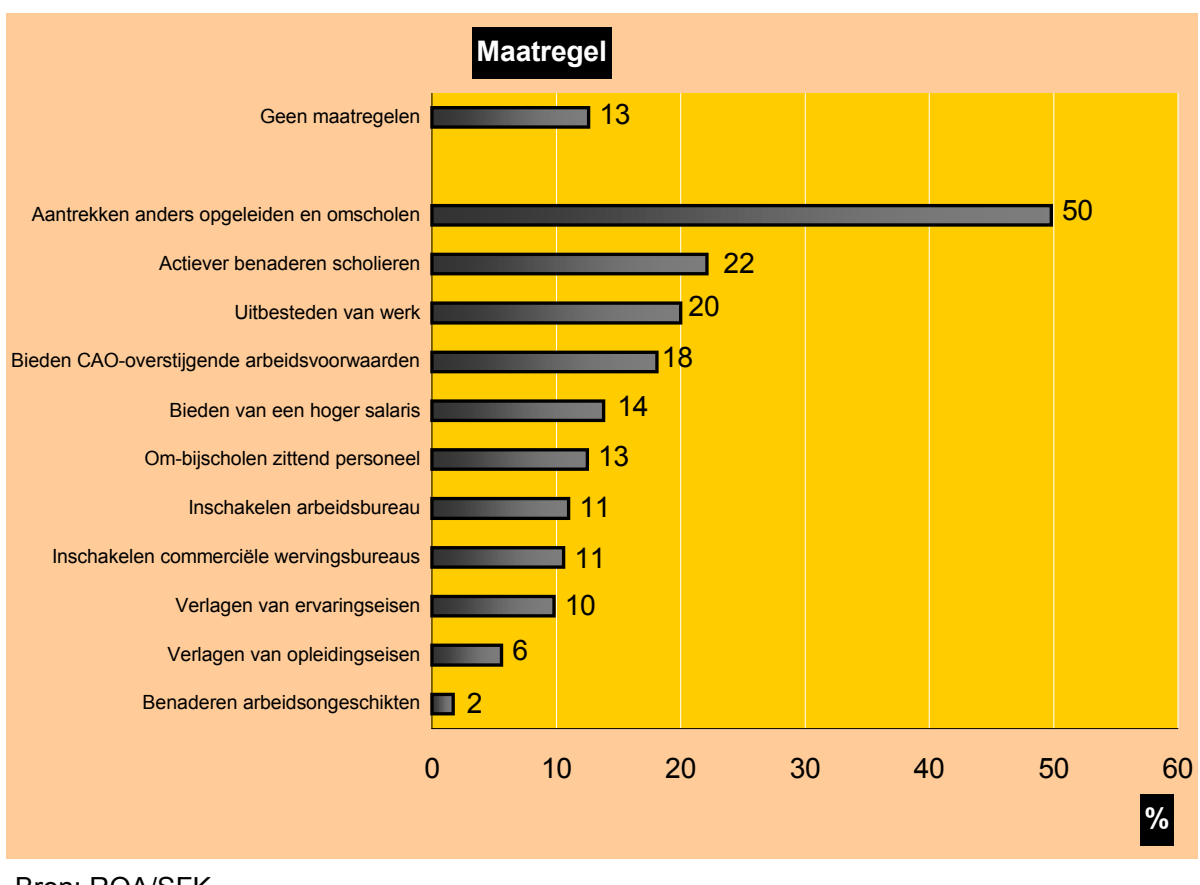

Bron: ROA/SFK

De regionale verschillen zijn, zoals reeds aangegeven, wat groter. Een voorbeeld hiervan is dat het aantrekken van anders opgeleiden in de regio's Noordwest en Middenwest (ruim 60\%) veel vaker voorkomt dan in de regio's Noord, Oost en Zuidwest (minder dan 40\%). In de regio Noordwest is bovendien het percentage apotheken dat een hoger salaris biedt om potentiële werknemers aan te trekken met $33 \%$ aanzienlijk hoger dan in de andere regio's, waar dat percentage op $12 \%$ of lager ligt. Ook bestaat in deze regio relatief veel aandacht voor om- en bijscholing van de eigen werknemers als maatregel om in openstaande vacatures te voorzien. Dit maakt duidelijk dat de grotere knelpunten in de personeelsvoorziening van de apotheken in het westen van het land, de apotheken noodzaken tot allerlei aanpassingen in hun wervingsbeleid. 
Ook de omvang van de apotheek blijkt enig verschil te maken voor wat betreft de gekozen maatregelen om bij problemen toch de vacatures vervuld te krijgen. Zo zijn het de kleinere apotheken die het salaris verhogen en de grotere (veelal zelfstandige). Het uitbesteden van werk en het actiever benaderen van scholieren wordt vaker door grotere apotheken genoemd dan door de kleinere. Omscholing van anders opgeleiden en om- en bijscholing van zittend personeel worden vooral door middelgrote apotheken weinig genoemd. Verlagen van opleidings- en ervaringseisen juist weer opvallend vaak.

\section{Wervingskanalen}

De werving van nieuwe apothekersassistenten kan op veel verschillende manieren plaatsvinden. Zoals figuur 4.2 laat zien is het meest gebruikte wervingskanaal nog altijd de advertentie. Van de apothekers die nieuwe apothekersassistenten hebben aangetrokken gebruikt bijna 55\% bij de werving dit 'klassieke' wervingskanaal. Bijna $43 \%$ van alle apothekers gebruikte het eigen netwerk bij het vinden van nieuwe apothekersassistenten. Commerciële wervingsbureaus en arbeidsbureaus (CWl's) worden door apothekers nauwelijks ingeschakeld. Het actief werven van (gedeeltelijk) arbeidsongeschikten gebeurt ook vrijwel niet. Apothekers die te maken hebben met veel vacatures zetten overigens meerdere wervingskanalen tegelijk in.

Figuur 4.2

Kanalen gebruikt bij de werving van apothekersassistenten, 2001

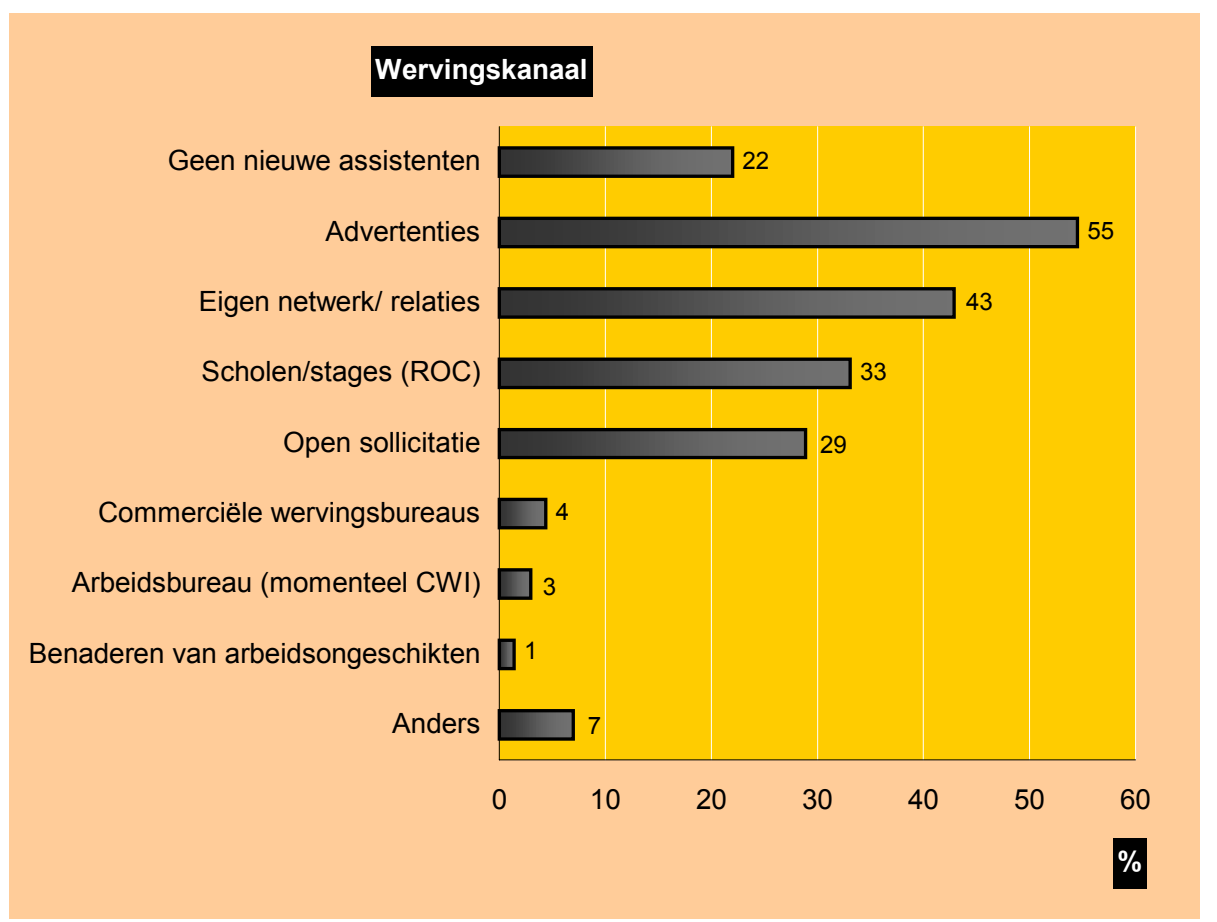

Bron: ROA/SFK 
Apotheken die deel uitmaken van een grote apotheekgroep blijken de open sollicitatie veel minder vaak als wervingskanaal te gebruiken dan zelfstandige apotheken en apotheken die deel uitmaken van een kleine apotheekgroep. De kleine apotheekgroepen plaatsen daarentegen veel vaker een advertentie. De overige wervingskanalen worden door alle apotheken ongeveer evenveel gebruikt.

Ook zijn er verschillen tussen de regio's. Apotheken in de regio Zuidoost werven bijvoorbeeld heel wat vaker via hun eigen netwerk, via arbeidsbureaus (CWI's) en/of via scholen dan apotheken in de regio Zuidwest en Middenwest. Het arbeidsbureau werd in de regio Middenwest zelfs door geen enkele apotheek ingeschakeld. In de regio Oost werd weer veel vaker gebruik gemaakt van commerciële wervingsbureaus dan in bijvoorbeeld de regio Noordwest. De open sollicitatie en de advertentie werd in de regio Noordwest relatief veel gebruikt.

In grote apotheken wordt relatief veel gebruik gemaakt van open sollicitaties en advertenties om aan nieuwe assistenten te komen. In de allerkleinste apotheken blijft bovendien het werven via de ROC's en stages en via commerciële wervingsburo's achter. Ook het eigen netwerk wordt door de kleinste apotheken minder gebruikt als wervingskanaal.

\section{Voorkeuren van apothekers}

Waar gaat bij de werving van apothekersassistenten nu de voorkeur naar uit? Zijn dat herintreders, die weliswaar ervaring meebrengen, maar wel een aantal jaren uit het vak zijn, of zijn het vooral de schoolverlaters van de apothekersassistentenopleidingen, die wat minder ervaring hebben, maar daar meer actuele kennis tegenover stellen.

Recent onderzoek naar de personeelsselectie in de zorgsector wijst uit dat juist in die sector ervaring regelmatig belangrijker wordt gevonden dan een juiste opleiding. ${ }^{18} \mathrm{De}$ voorkeuren van apothekers zijn echter opvallend anders. Figuur 4.3 laat zien dat apothekers bij het aantrekken van nieuwe apothekersassistenten een duidelijke voorkeur hebben voor gediplomeerde schoolverlaters en werkenden uit een andere apotheek boven herintreders. Op een voorkeursschaal van 1 (nooit aannemen) tot 10 (eerste keus) krijgt de schoolverlater van de apothekers gemiddeld een 8,7 en de werkende uit een andere apotheek een 8,1. De herintreder scoort met een 5,7 aanzienlijk lager. Vroegere werkervaring blijkt dus voor de apothekers niet op te wegen tegen actuele kennis en vaardigheden. Recente werkervaring blijkt echter wel van belang.

De voorkeur voor schoolverlaters is het grootst in de regio Zuidoost (9). Herintreders $(5,4)$ en werknemers van andere apotheken $(7,9)$ scoren in deze regio heel wat lager. De voorkeur voor schoolverlaters boven werknemers van een andere apotheek is het minst eenduidig in de regio Noord. Herintreders zijn echter in alle andere

18. Zie W. Smits, Personeelsselectie in de Zorg, de Metaalindustrie en de IT, ROA-W-2001/2, Maastricht, 2001. 
regio's, dus ook in de regio Noord, het minst gewild. De voorkeur voor herintreders neemt doorgaans toe naarmate er meer knelpunten in de personeelsvoorziening zijn in een regio. In de regio's Noordwest en Middenwest, de beide regio's met de meeste vacatures, is de voorkeur voor herintreders groter dan in de andere regio's. Dit kan er op duiden dat apothekers als gevolg van knelpunten in de personeelsvoorziening hun wervingsstrategie aanpassen.

Apothekers zijn echter, ondanks hun duidelijke voorkeur voor schoolverlaters of reeds werkzame assistenten, in grote mate bereid extra inspanningen te doen om ook herintreders in dienst te nemen. ${ }^{19} 9$ Van de 10 apothekers geven aan best wat extra's te willen doen om herintreders aan te trekken.

\section{Figuur 4.3}

Voorkeuren van apothekers bij selectie van apothekersassistenten, 2001

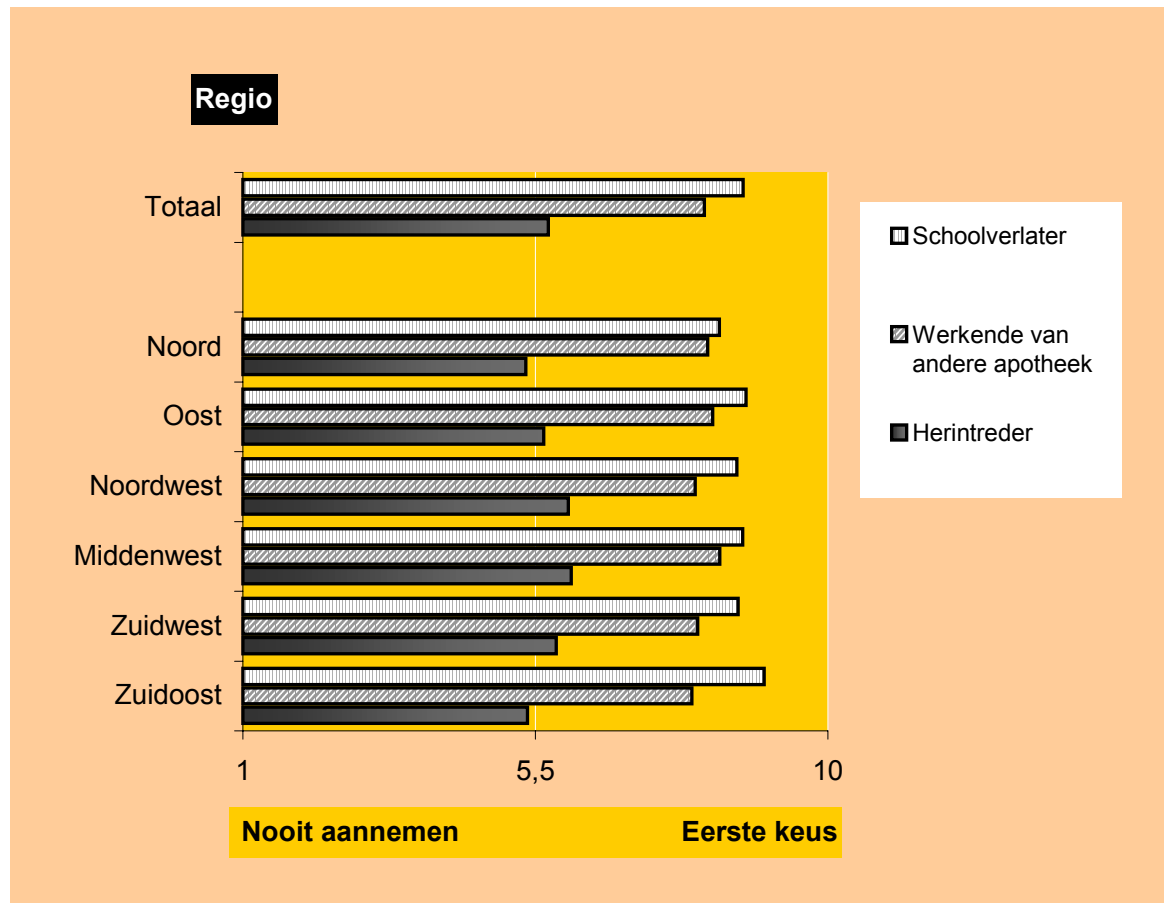

Bron: ROA/SFK

Wat dat betreft zijn apothekers net zo bereid extra inspanningen te leveren voor herintreders als voor schoolverlaters. Het merendeel van de apothekers denkt daarbij vooral aan bijscholing en het aanstellen van een begeleider. lets meer dan de helft van de apothekers wil bovendien de werktijden aanpassen aan de wensen van de herintreder. Voor schoolverlaters is men daartoe wat minder bereid.

Met name apotheken die tot een kleine apotheekgroep behoren hebben een grote inspanningsbereidheid als het gaat om herintreders. Vooral het aanstellen van een

19. Geen enkele apotheker geeft aan nooit herintreders aan te zullen nemen. 
begeleider wordt in deze apotheken veel genoemd. Bij de zelfstandige apotheken is de inspanningsbereidheid voor zowel herintreders als schoolverlaters wat lager dan bij de ketenapotheken.

De regionale verbijzondering laat zien dat apothekers in de regio Noord wat vaker tot extra inspanningen bereid zijn dan apothekers in andere regio's. Vooral de mate waarin apothekers in deze regio aangeven de werktijden te willen aanpassen aan de wensen van de schoolverlaters is aanzienlijk hoger dan in andere regio's. In mindere mate geldt dat ook voor de bereidheid de werktijden aan te passen aan de wensen van herintreders. Dit zou erop kunnen wijzen dat de apothekers in het Noorden van het land minder veel met knelpunten in de personeelsvoorziening worden geconfronteerd, omdat ze er gemakkelijker in slagen in te spelen op de specifieke wensen van sollicitanten. Aan de andere kant kan het ook zo zijn dat een apotheker in deze regio wat gemakkelijker kan inspelen op de behoeften van assistenten om op bepaalde tijden of in deeltijd te gaan werken, juist omdát men wat minder krap in het personeel zit. Ook kan het zo zijn dat een sollicitant minder hoge eisen stelt als gevolg van de situatie op de arbeidsmarkt.

In de regio Noordwest is men het meest bereid om extra inspanningen te leveren om schoolverlaters aan te kunnen trekken. De apothekers die wat extra's willen doen, richten zich vaker dan in andere regio's, op het aanstellen van een begeleider voor de inwerkperiode, het aanbieden van lonen boven de CAO-schalen en het bieden van CAO-overstijgende secundaire arbeidsvoorwaarden.

De omvang van de apotheek heeft nauwelijks invloed op de mate waarin apothekers bereid zijn extra inspanningen te leveren om schoolverlaters danwel herintreders aan te trekken. Apothekers in grote apotheken zijn wat vaker bereid een begeleider aan te stellen voor een herintreder of schoolverlater. Apothekers in kleine apotheken bieden daarentegen wat vaker een hoger loon aan de herintreder. Dat doen zij overigens minder snel voor een schoolverlater.

Schema 4.1 laat zien dat in apotheken die deel uitmaken van een groep van hooguit 4 apotheken de inspanningen meer gericht zijn op schoolverlaters, terwijl de zelfstandige apotheken en ook de grotere apotheekgroepen over het algemeen wat meer gericht zijn op herintreders. Ook hieruit valt af te leiden dat naarmate het aantal vacatures toeneemt apothekers meer inspanningen willen leveren om ook herintreders aan te trekken. In de apotheken die deel uitmaken van een kleine groep is de vacaturegraad immers lager dan in zelfstandige apotheken en apotheken die deel uitmaken van een grote groep.

De regio's Noordwest en Noord komen naar voren als de meest actieve regio's als het gaat om inspanningen gericht op schoolverlaters. De regio's Noordwest en Middenwest als het gaat om herintreders. Ook hier geldt dat dit juist de regio's zijn met de hoogste vacaturegraad. De grootste en de kleinste categorie apotheken zijn wat actiever in hun benadering van schoolverlaters en herintreders dan de middelgrote en grote apotheken. 
Schema 4.1

Inspanningsbereidheid voor het aantrekken van schoolverlaters en herintreders, 2001

\begin{tabular}{|c|c|c|c|c|}
\hline \multirow{2}{*}{$\begin{array}{l}\text { Inspanning } \\
\text { gericht op: }\end{array}$} & \multirow[t]{2}{*}{ Inspanning: } & \multicolumn{3}{|c|}{ Meest inspanningsbereid: } \\
\hline & & Soort apotheek & Regio & Omvang \\
\hline Schoolverlater & $\begin{array}{l}\text { Begeleider voor } \\
\text { inwerkperiode } \\
\text { Aanpassen werktij- } \\
\text { den } \\
\text { Loon boven CAO } \\
\text { Secundaire arbeids- } \\
\text { voorwaarden boven } \\
\text { CAO } \\
\text { Bijscholing }\end{array}$ & $\begin{array}{l}\text { Kleine apotheekgroep } \\
\text { Kleine apotheekgroep } \\
\text { Kleine apotheekgroep } \\
\text { Grote apotheekgroep }\end{array}$ & $\begin{array}{l}\text { Noordwest } \\
\text { Noord } \\
\text { Noordwest } \\
\text { Noordwest }\end{array}$ & $\begin{array}{l}\text { Erg groot } \\
\text { Klein } \\
\text { Erg groot } \\
\text { Klein }\end{array}$ \\
\hline Herintreder & $\begin{array}{l}\text { Begeleider voor } \\
\text { inwerkperiode } \\
\text { Aanpassen werktij- } \\
\text { den } \\
\text { Loon boven CAO } \\
\text { Secundaire arbeids- } \\
\text { voorwaar-den boven } \\
\text { CAO } \\
\text { Bijscholing }\end{array}$ & $\begin{array}{l}\text { Kleine apotheekgroep } \\
\text { Zelfstandige apotheek } \\
\text { Zelfstandige apotheek } \\
\text { Grote apotheekgroep }\end{array}$ & $\begin{array}{l}\text { Noordwest } \\
\text { Noordwest } \\
\text { Noordwest } \\
\text { Noordwest }\end{array}$ & $\begin{array}{l}\text { Erg groot } \\
\text { Erg groot } \\
\text { Klein } \\
\text { Erg groot }\end{array}$ \\
\hline
\end{tabular}

$B O L / B B L$ stagiaires en leerling-apothekersassistenten

Uit figuur 4.2 viel al op te maken dat zo'n één op de drie apotheken nieuwe apothekersassistenten in dienst heeft genomen via scholen en stages. Bovendien hebben apothekers bij het aantrekken van nieuwe apothekersassistenten een duidelijke voorkeur voor schoolverlaters boven herintreders en werknemers van andere apotheken. Dat maakt het interessant om meer inzicht te krijgen in het aantal apotheken dat leerling-apothekersassistenten van de beroepsbegeleidende leerweg (BBL, het voormalige Leerlingwezen) of stagiaires van de beroepsopleidende leerweg (BOL) in dienst heeft en de manier waarop apothekers met deze BOL- en BBL'ers omgaan.

\section{BeroepsOpleidende Leerweg (BOL)}

Figuur 4.4 laat zien dat in $75 \%$ van de apotheken één of meerdere stagiaires van de Beroepsopleidende Leerweg (BOL) werkzaam zijn. Van de apotheken die een BOL stagiaire in dienst hebben heeft $80 \%$ één stagiaire in dienst en $17 \%$ twee stagiaires.

Apotheken die tot een apotheekgroep met hooguit 4 apotheken behoren hebben iets vaker een BOL stagiaire in dienst dan andere apotheken, maar het verschil is erg klein. De regionale verschillen zijn wat groter. Apotheken in de regio's Middenwest $(66 \%)$ en Noordwest $(71 \%)$ hebben beduidend minder vaak een BOL stagiaire in 
dienst dan apotheken in de regio's Oost (81\%) en vooral Zuidwest (85\%). Vooral de wat grotere apotheken hebben veel BOL stagiaires in dienst. Mogelijk komt dat doordat het in kleinere apotheken wat moeilijker is om voldoende begeleiding te geven.

Figuur 4.4

Percentage apotheken dat BOL stagiaires en/of BBL leerlingen in dienst heeft, 2001

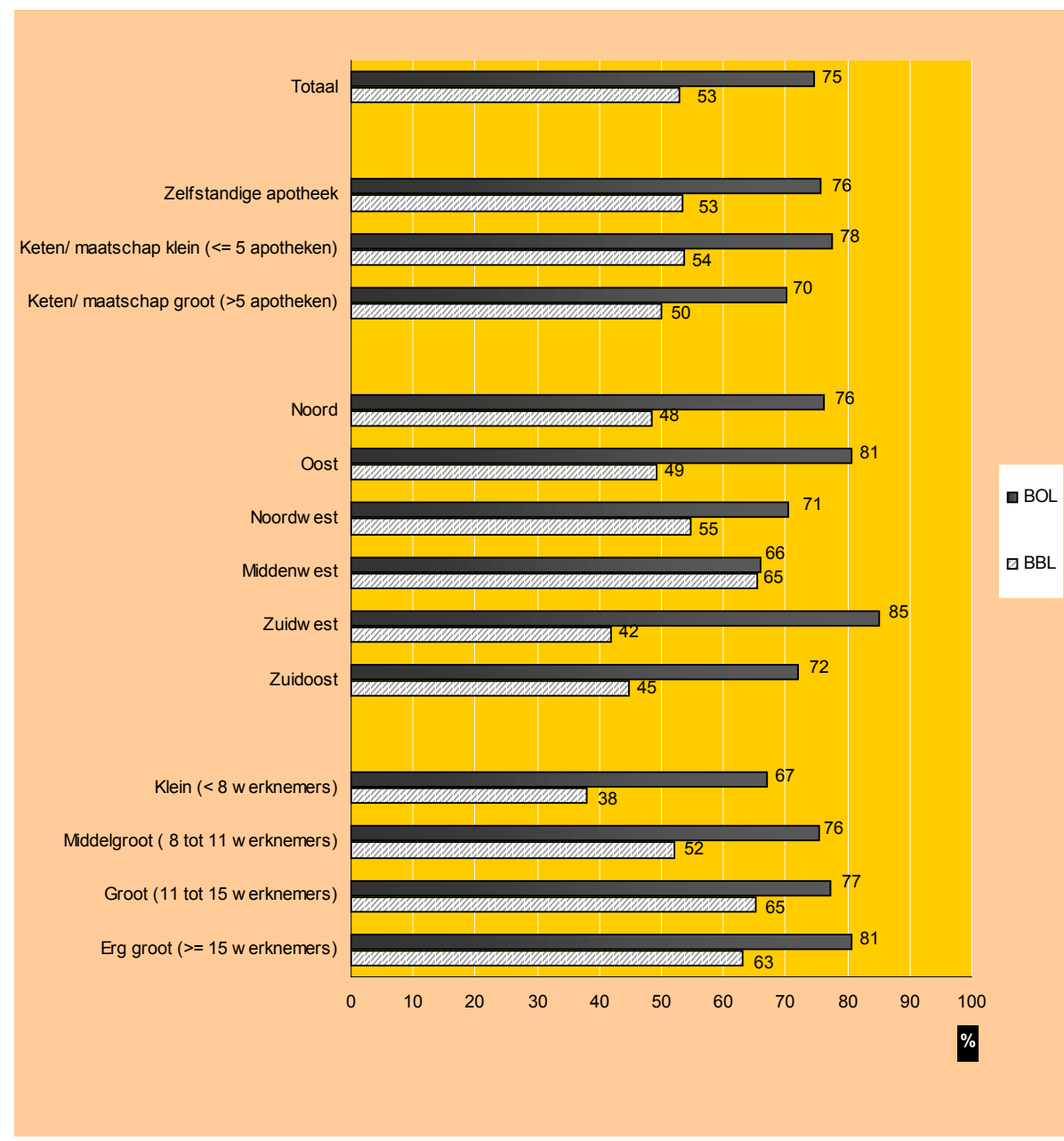

Bron: ROA/SFK

lets meer dan eenderde van de BOL stagiaires krijgt van de apotheek waar zij werkzaam zijn een vorm van vergoeding. Dat percentage verschilt sterk per soort apotheek. In de zelfstandige apotheken krijgt bijna $40 \%$ van de BOL stagiaires een of andere vergoeding. In de apotheken die deel uitmaken van een groep van 5 of meer apotheken nog geen $22 \%$. 
Ook de regionale verschillen zijn opvallend groot. In de regio Noordwest krijgt bijna driekwart van de BOL stagiaires een vergoeding, terwijl in de regio's Zuidoost, Noord en Oost amper één op de vijf BOL stagiaires een vergoeding krijgt. De knelpunten in de regio Noordwest maken het duidelijk noodzakelijk voor apothekers om ook stagiaires beter te belonen om hen in huis te halen en te houden.

\section{Figuur 4.5}

Percentage apotheken dat BOL'ers en BBL'ers een vergoeding geeft, 2001

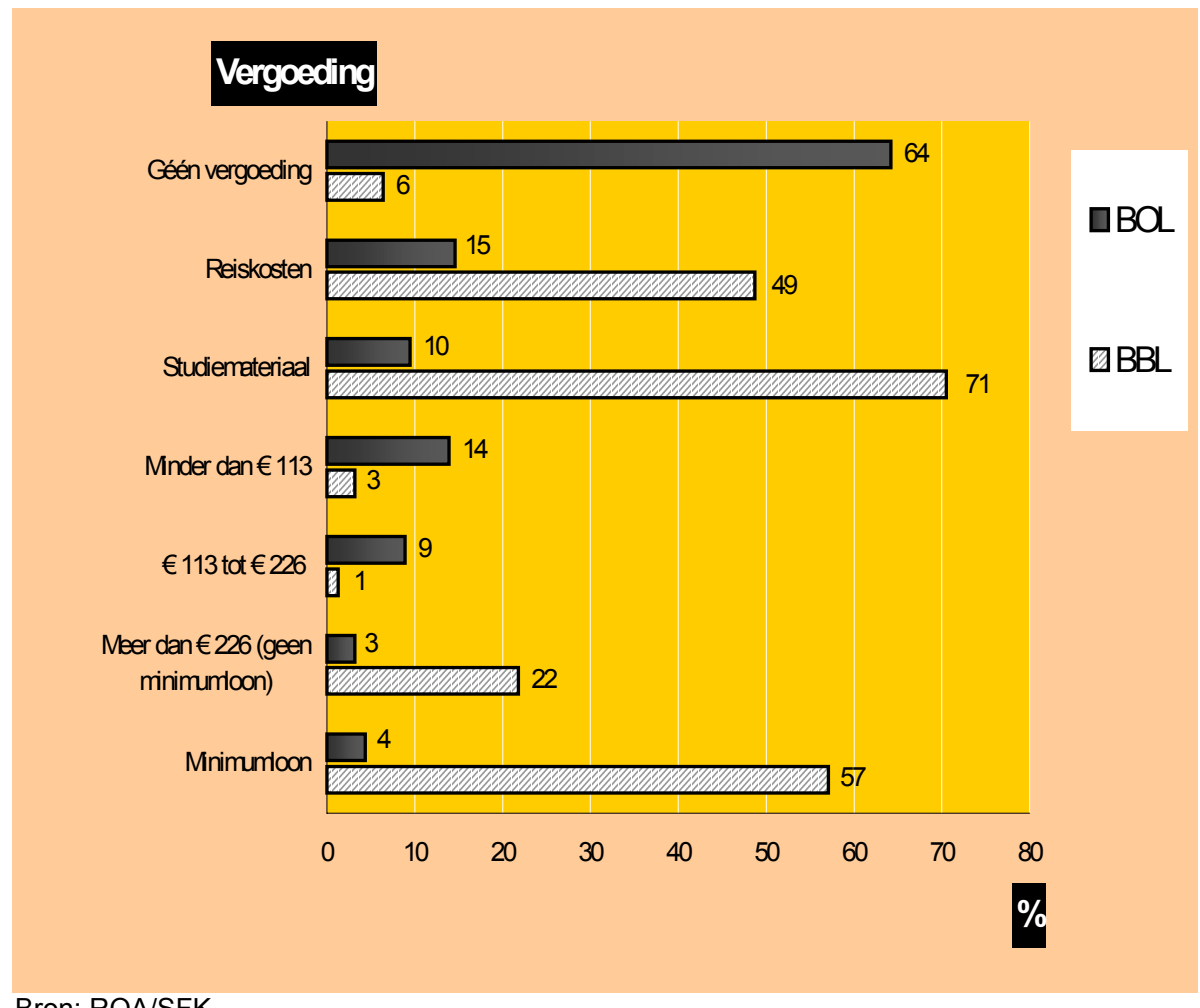

Bron: ROA/SFK

De vergoeding die stagiaires krijgen bestaat meestal uit een maandelijks geldbedrag tot $€ 113,00$ of een reiskostenvergoeding (zie figuur 4.5). Een vergoeding op het niveau van het minimumloon is veel minder gebruikelijk. Apotheken die deel uitmaken van een grote apotheekgroep en apotheken van kleine omvang betalen BOL stagiaires overigens wat vaker het minimumloon. In middelgrote en grote apotheken en in apotheken die deel uitmaken van een kleine apotheekgroep zijn vergoedingen van $€ 113,00$ tot $€ 226,00$ gebruikelijker.

\section{BeroepsBegeleidende Leerweg (BBL)}

Het in dienst nemen van leerlingen van de BBL opleiding tot apothekersassistent vergt meer inspanning van de apotheker en zijn of haar assistenten. Met name op 
het gebied van begeleiding. Het grootste deel van de opleiding van de BBL'er bestaat immers uit praktijkvorming. Over het algemeen zijn er ook minder BBL'ers in dienst dan BOL'ers (zie figuur 4.4). lets meer dan de helft van de apotheken heeft niettemin één of meerdere BBL leerlingen in dienst, waarbij het overgrote deel echter niet meer dan één BBL'er in dienst heeft. Kleine apotheken hebben logischerwijs wat minder vaak een BBL leerling in dienst dan grotere apotheken.

Van de BBL'ers krijgt, zo blijkt uit figuur 4.5, 94\% een of andere vergoeding. Slechts $60 \%$ van de apothekers die een vergoeding geeft aan BBL'ers, doet dat in de vorm van het minimumloon. De zelfstandige apotheken en de apotheken die deel uitmaken van een grote apotheekgroep betalen het minimumloon overigens minder vaak dan de apotheken die tot een kleine apotheekgroep behoren. Ook de regionale verschillen zijn aanzienlijk. Apothekers in de regio Noord betalen veel minder dan de apothekers in de regio Zuidoost. Mogelijk hangt dit samen met de verwachting van de apothekers in de regio Zuidoost dat het personeelsverloop zal toenemen. Investeren in stagiaires is voor deze apothekers kennelijk een manier om die toename te voorkomen.

Ook blijkt dat kleine apotheken minder vaak het minimumloon betalen dan (erg) grote apotheken.

\section{Assistenten over het begeleiden van stagiaires: \\ "De werkdruk is heel hoog, dus hebben we over het algemeen vrij weinig tijd voor goede begeleiding" \\ "We werken niet met vaste begeleiders. Wie er tijd voor heeft begeleidt ze" \\ "Oppassen voor teveel stagiaires, want we moeten wel tijd houden om ons werk te blijven doen" \\ "We hebben geen stagiaires en dat is een bewuste keuze. We hebben te weinig tijd om ze voldoende aandacht te geven" \\ "We hebben geen stagiaires. We krijgen wel brieven, maar we hebben niets voor ze te doen"}

Bron: SBA berichten, jaargang 8, Nr. 4, April 2002

Uit de cijfers over de begeleidingstijd die apothekers gemiddeld per week kwijt zijn (zie tabel 4.1) blijkt overigens dat de begeleiding van stagiaires in kleine apotheken wat meer tijd vergt dan in grotere apotheken. Dit kan overigens ook komen omdat apothekers in kleine apotheken zelf meer van de aanwezigheid van leerlingen of stagiaires merken dan apothekers in grote apotheken. Dit kan een verklaring zijn voor het feit dat kleine apotheken over het algemeen minder stagiaires en leerling assistenten in dienst nemen dan grote apotheken. 
Tabel 4.1

Gemiddeld aantal uren dat per week in een apotheek aan de begeleiding van alle BOL en BBL leerlingen wordt besteed, 2001

\begin{tabular}{lcc}
\hline & BOL & BBL \\
\hline Totaal & 8 & 7 \\
Zelfstandige apotheek & 8 & 8 \\
Kleine apotheekgroep (<5 apotheken) & 8 & 7 \\
Grote apotheekgroep ( $\geq 5$ apotheken) & 8 & 6 \\
Noord & 7 & 6 \\
Oost & 8 & 9 \\
Noordwest & 9 & 8 \\
Middenwest & 6 & 6 \\
Zuidwest & 10 & 7 \\
Zuidoost & 8 & 7 \\
Klein (<60.000 voorschriften) & 10 & 8 \\
Middelgroot (60.000-80.000) & 7 & 7 \\
Groot (80.000-100.000) & 8 & 8 \\
Erg groot (>100.000) & 8 & 6 \\
\hline Bron: ROA/SFK & & \\
\hline
\end{tabular}

Bron: ROA/SFK

\subsection{Human Resources Development}

In deze paragraaf zal worden ingegaan op de wijze waarop apotheken trachten de kennis en vaardigheden van hun assistenten op peil te houden en hen klaar te stomen voor veranderingen die zich in de apotheek voordoen. Daartoe is vanzelfsprekend het volgen van cursussen en opleidingen van groot belang. Het gaat hier in feite om het in stand houden van het menselijk kapitaal van de organisatie door middel van het zogenaamde Human Resources Development (HRD). Dit vormt het tweede centrale element in het HRM beleid van een organisatie.

In deze paragraaf wordt achtereenvolgens ingegaan op de volgende vragen:

- In welke mate worden cursussen gevolgd en wat voor soort cursussen worden er gevolgd?

- In hoeverre gaat het om door de SBA geaccrediteerde cursussen?

- Wie nam het initiatief om een cursus te gaan volgen? en;

- Werd de cursus in werktijd of in eigen tijd gevolgd?

\section{Gevolgde cursussen}

Tabel 4.2 laat zien dat in de apothekersbranche met name veel aandacht bestaat voor vaktechnische cursussen op het gebied van de geneesmiddelenkennis en de kennis van ziektebeelden. De minste aandacht is er voor cursussen op het gebied van recepteren van geneesmiddelen en het zelfstandig werken. Vooral het zelfstandig kunnen werken lijkt een vaardigheid die bij uitstek verkregen wordt door het in de praktijk te leren.

Gemiddeld $56 \%$ van de gevolgde cursussen is door de SBA geaccrediteerd. Het accent ligt daarbij duidelijk op de vakinhoudelijke kennisontwikkeling (genees- 
middelenkennis, kennis van ziektebeelden en bereiden en recepteren van geneesmiddelen). De meeste geaccrediteerde cursussen worden gevolgd op het gebied van geneesmiddelenkennis, de minste op het gebied van computervaardigheden.

Grote verschillen zijn er niet als we kijken naar de cursusdeelname per soort apotheek, zij het dat computertrainingen wat vaker worden gevolgd door apothekersassistenten in de apotheken die tot een apotheekgroep van 5 of meer apotheken behoren. Een oorzaak van de hoge deelname aan deze cursussen in grote apotheekgroepen is dat vooral in deze apotheken het in gebruik nemen van nieuwe computersystemen voor veel veranderingen zorgt in de werkzaamheden van de apothekersassistenten. Cursussen op het gebied van de informatievoorziening over geneesmiddelen worden daarentegen wat minder vaak in de apotheken die tot een apotheekgroep van 5 of meer apotheken behoren gevolgd. Dat is opvallend omdat de apothekersassistenten in die apotheken naar verhouding wat meer onvoldoendes krijgen voor de manier waarop zij informatie verstrekken.

Tabel 4.2

Percentage apotheken waarvan de assistenten een bepaalde cursus hebben gevolgd, 2001

\begin{tabular}{lcc}
\hline & & $\begin{array}{c}\text { Waarvan SBA } \\
\text { geaccrediteerd } \\
\%\end{array}$ \\
& $\%$ & \\
\hline Geneesmiddelenkennis & & 71 \\
Kennis van ziektebeelden & 60 & 66 \\
Informatievoorziening geneesmiddelen & 42 & 48 \\
Communicatieve vaardigheden & 30 & 38 \\
Computervaardigheden & 22 & 6 \\
Omgaan met collegae & 19 & 27 \\
Bereiding van geneesmiddelen & 8 & 64 \\
Omgaan met verantwoordelijkheid & 5 & 63 \\
Recepteren van geneesmiddelen & 5 & 14 \\
Zelfstandigheid & 4 & \\
& 3 & \\
\hline Bron: ROAJFK & & \\
\hline
\end{tabular}

Bron: ROA/SFK

Een mogelijke verklaring voor het feit dat niettemin weinig cursussen worden gevolgd is dat apothekers in apotheken die tot een grote apotheekgroep behoren de intensivering van de patiëntenvoorlichting wat minder vaak als een belangrijke verandering zien in de werkzaamheden van apothekersassistenten. De behoefte aan cursussen op het gebied van informatieverstrekking is daardoor mogelijk wat minder groot.

Regionale verschillen zijn er allereerst voor wat betreft de deelname aan cursussen op het gebied van de geneesmiddelenkennis. ${ }^{20}$ Dergelijke cursussen worden vooral veel gevolgd door assistenten in de regio Zuidoost. In de regio Noordwest is de deelname bijna 20\%-punt lager. Dat is opvallend omdat vooral apothekers in de regio Noordwest aangeven dat veranderingen in de vereiste geneesmiddelenkennis de

20. Omdat het aanbod van cursussen in een departement door de regiocoördinator (in samenspraak met de departementsbesturen) wordt vastgesteld betekent een geringe deelname niet per definitie dat weinig behoefte bestaat aan specifieke training. Het aanbod van cursussen kan in een departement immers beperkt zijn als gevolg van de prioritering door regiocoördinator en departementshoofden. 
werkzaamheden van assistenten zullen beïnvloeden. De problemen met de bezetting, die zich vooral ook in de regio Noordwest voordoen, laten mogelijk geen ruimte voor het volgen van bepaalde cursussen.

In de regio Zuidoost worden veel cursussen op het gebied van de geneesmiddelenkennis gevolgd. Gezien het relatief hoge percentage apothekersassistenten dat in deze regio voor hun geneesmiddelenkennis een onvoldoende scoort is dit minder verrassend. Het volgen van deze cursussen zou in de regio Zuidoost een bijdrage kunnen leveren aan het verminderen van deze skill-gap bij apothekersassistenten.

In de regio Noord wordt door assistenten relatief weinig gedaan aan scholing op het gebied van informatieverstrekking over geneesmiddelen. In de regio's Oost, Noordwest en Zuidwest worden dergelijke cursussen heel wat vaker gevolgd. Een mogelijke verklaring is dat apothekers in de regio Noord uitermate tevreden zijn over de manier waarop assistenten informatie verstrekken. In deze regio viel geen enkele onvoldoende voor deze competentie en wordt het volgen van een cursus op dit terrein kennelijk dan ook minder van belang geacht.

In de regio Zuidwest is ten slotte opvallend veel aandacht voor cursussen op het gebied van bereidingen van geneesmiddelen. Hiervoor is in ieder geval aan de hand van gegevens over competenties geen goede verklaring te geven. Wel blijkt dat in de regio Zuidwest het minst vaak door apothekers wordt aangegeven dat het doen van minder bereidingen een belangrijke verandering is in het werk van de apothekersassistenten.

De cursusdeelname in de erg grote apotheken is over het algemeen het hoogst. Het verschil tussen grote en kleine apotheken is met name opvallend voor wat betreft de cursusdeelname op het gebied van het omgaan met collega's. Dat de erg grote apotheken assistenten hierin trachten te trainen hangt mogelijk samen met het iets hogere percentage onvoldoendes van de assistenten voor deze competentie. Een andere verklaring is dat in een grote apotheek nu eenmaal meer assistenten werkzaam zijn, waarmee samengewerkt moet worden. Dat vereist meer aandacht voor de omgang met collega's, waardoor er eerder aanleiding is om trainingen op dit gebied te volgen. Ook vakinhoudelijke cursussen op het gebied van de geneesmiddelenkennis, de bereiding van geneesmiddelen en de kennis van ziektebeelden worden heel wat vaker gevolgd in de erg grote apotheken dan in de kleinere apotheken.

Initiatief $^{21}$

In figuur 4.6 wordt aangegeven wie het initiatief nam om een cursus te gaan volgen.

Meestal nemen apothekers en assistenten samen het initiatief voor een cursus. Een belangrijke uitzondering hierop zijn de cursussen gericht op het vergroten van de

21. In de CAO Apotheken 2001 is geregeld dat cursussen op initiatief van de apotheker altijd volledig door de apotheker betaald worden, datzelfde geldt voor SBA geaccrediteerde cursussen op initiatief van de apothekersassistent. Deze regeling zou invloed kunnen hebben op de onderzoeksresultaten. 
zelfstandigheid van de apothekersassistenten. Hier ligt het initiatief wat vaker bij de apotheker of de assistent. Opvallend is dat het initiatief voor het volgen van meer vakinhoudelijke cursussen, zoals cursussen op het gebied van ziektebeeldkennis en geneesmiddelenkennis of cursussen op het gebied van recepteren en bereiden van geneesmiddelen, vaak bij de assistent ligt en niet zozeer bij de apotheker. De cursussen die zich richten op meer algemene vaardigheden als computervaardigheden, communicatieve vaardigheden, omgaan met collega's en omgaan met verantwoordelijkheid worden daarentegen weer vaker door de apotheker geïnitieerd dan door de assistenten. Dit illustreert de sterke vakinhoudelijke focus van veel apothekersassistenten die ook al bleek uit gegevens over de door assistenten ingeschatte kans op het vinden van een even aantrekkelijke baan buiten de sector.

Figuur 4.6

Initiatiefnemer bij de gevolgde cursussen, 2001

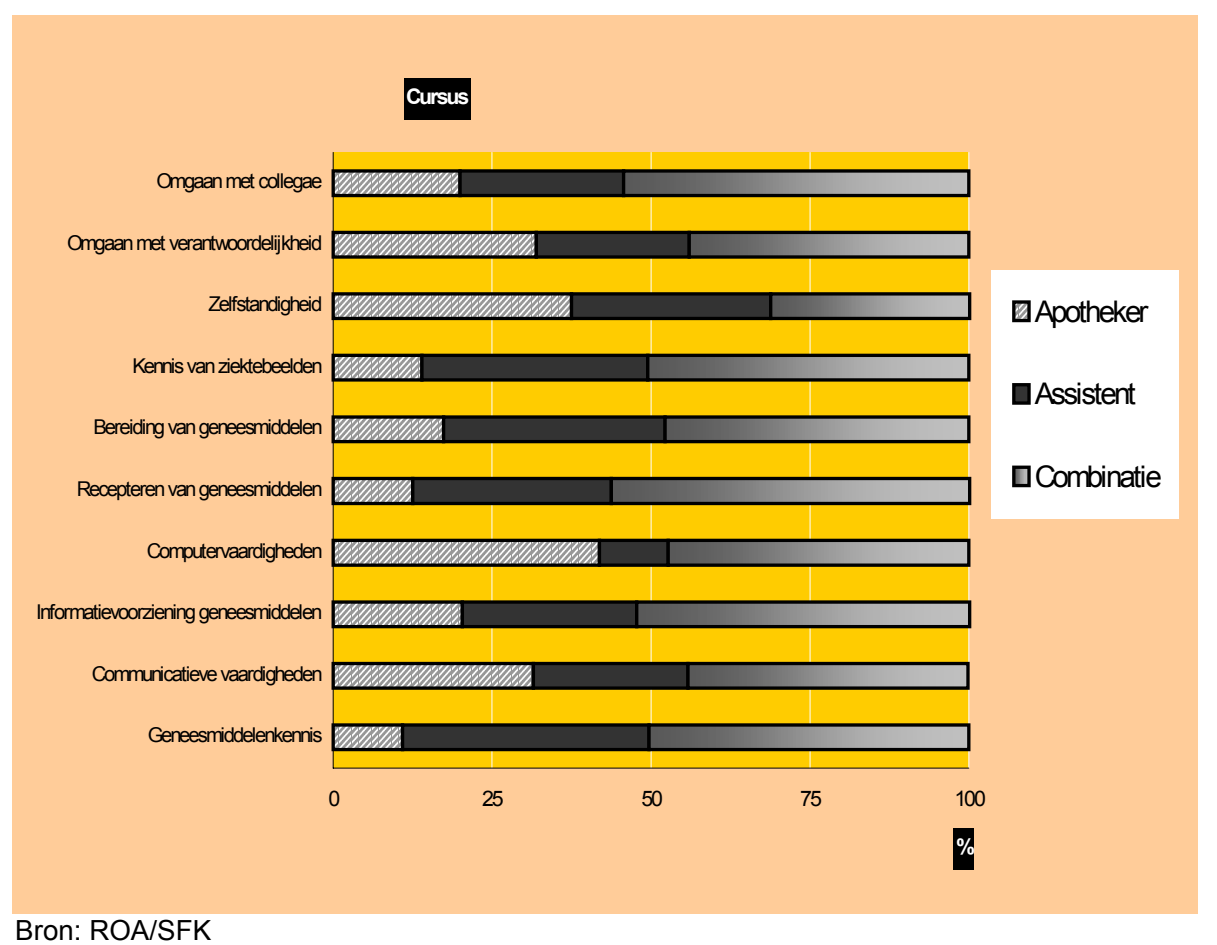

Verschillen tussen de soorten apotheken en regionale verschillen zijn er nauwelijks. Wel blijkt dat het in kleine apotheken wat vaker de apotheker is dan de assistent die het initiatief neemt tot het volgen van een cursus, terwijl in grote apotheken vaak van een gezamenlijk initiatief of een initiatief van de assistent sprake is. Dit kan betekenen dat apothekers in grote apotheken een minder goed zicht hebben op de cursusbehoeften van individuele assistenten dan apothekers in kleine apotheken. 
Figuur 4.7

Percentage cursussen dat gevolgd is in eigen tijd, werktijd en beiden, 2001

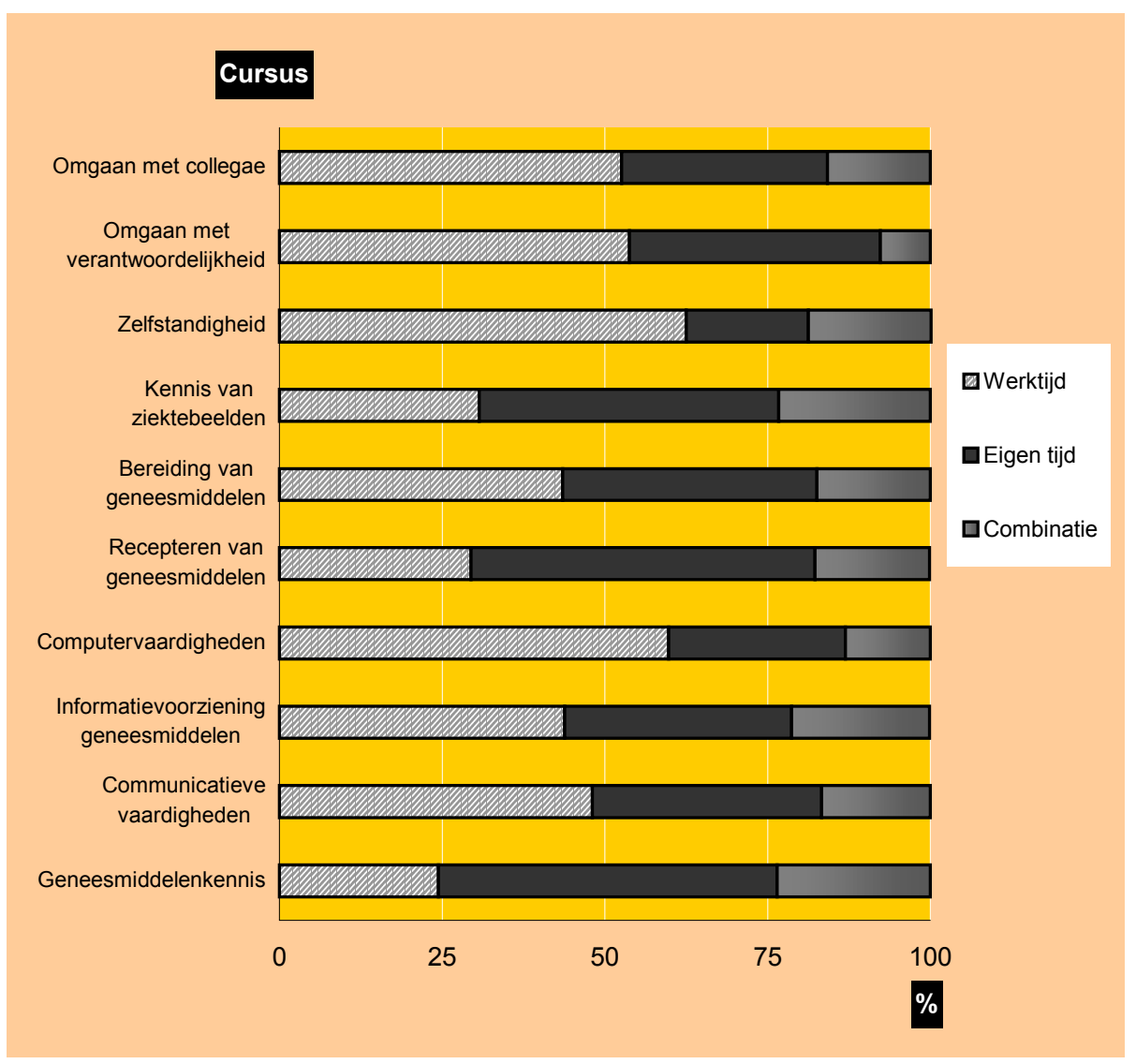

Bron: ROA/SFK

Eigen tijd, werktijd of een combinatie ${ }^{22}$

In figuur 4.7 wordt aangegeven of cursussen worden gevolgd in de eigen tijd van de apothekersassistent, in werktijd of een combinatie van beiden. Vaktechnische cursussen (op gebieden als kennis van ziektebeelden, geneesmiddelenkennis en recepteren en bereiden van geneesmiddelen) worden relatief vaak in eigen tijd gevolgd, terwijl meer algemene cursussen op het gebied van communicatieve en computervaardigheden, zelfstandigheid en omgaan met collega's en verantwoordelijkheid vaak in werktijd worden gevolgd. Dat strookt niet met de algemene gedachte dat training specifiek gericht op ontwikkelingen in de huidige functie op kosten van de werkgever (werktijd) wordt gevolgd en dat bij meer algemene training de kosten worden gedeeld (eigen tijd en werktijd) of door de werknemer zelf betaald (inleveren vrije tijd). Aan de andere kant is het wel weer in lijn met de constatering dat apothekersassistenten vaak het initiatief nemen tot het volgen van vakinhoudelijke

22. In de CAO Apotheken 2001 is vastgelegd dat ongeacht de tijd waarin een cursus wordt gevolgd de assistent recht heeft op doorbetaling van het volledige salaris. $\mathrm{De}$ onderzoeksresultaten zullen hierdoor dus niet aan geldigheid inboeten. 
cursussen, terwijl apothekers vaak het initiatief nemen voor niet-vakinhoudelijke trainingen. Wie het initiatief neemt tot het volgen van een cursus draait dus ook vaak op voor in ieder geval de indirecte kosten van een cursus.

Apothekers vinden het echter wel erg belangrijk dat er voldoende aandacht wordt besteed aan niet-vakinhoudelijke training. Zelfs zo belangrijk dat zij best bereid zijn het risico te nemen dat deze investeringen in de training van de assistenten ook buiten de apothekersbranche renderen. Overigens is dat risico over het algemeen vrij beperkt omdat de arbeidsmarkt voor apothekersassistenten een professionele vakdeelmarkt is. De uitwijkmogelijkheden van assistenten naar andere branches zijn vanwege hun vakspecifieke vooropleiding beperkt. Veel assistenten gaan er bovendien van uit dat buiten de sector het werk minder aantrekkelijk is. ${ }^{23} \mathrm{Zij}$ zullen dus niet zo snel van sector veranderen. Wel bestaat er een reële kans dat assistenten uitwijken naar de farmaceutische industrie.

Dat cursussen deels in eigen tijd en deels onder werktijd worden gevolgd komt niet zo vaak voor. Uitzonderingen zijn cursussen geneesmiddelenkennis, kennis van ziektebeelden en informatievoorziening geneesmiddelen. Dergelijke cursussen worden juist wat vaker deels in eigen tijd en deels onder werktijd gevolgd. In apotheken die deel uitmaken van een grote apotheekgroep worden vakinhoudelijke cursussen (geneesmiddelenkennis en kennis van ziektebeelden) veel vaker in werktijd gevolgd dan dat dat in zelfstandige of kleine apotheekgroepen het geval is. In zelfstandige en kleine apotheekgroepen worden deze vakinhoudelijke cursussen voornamelijk deels onder werktijd en deels in eigen tijd gevolgd. Voor wat betreft kennis van ziektebeelden is het zelfs zo dat in apotheekgroepen van 5 of meer apotheken de meeste cursussen in werktijd worden gevolgd en niet, zoals in andere apotheken het geval is, in de eigen tijd.

Regionale verschillen zijn er nauwelijks, zij het dat in de regio Zuidwest wat vaker cursussen onder werktijd worden gevolgd dan in eigen tijd. In de regio's Noordwest en Middenwest, de regio's met de grootste knelpunten, vinden vakinhoudelijke cursussen wat vaker in eigen tijd plaats en is de combinatie eigen tijd/werktijd wat minder gebruikelijk. Het lijkt er dus op dat naarmate de knelpunten toenemen apothekers minder geneigd zijn werktijd beschikbaar te stellen voor het volgen van cursussen. Dat is in ieder geval voor de regio Noordwest het geval. De omvang van de apotheek heeft nauwelijks invloed op de mate waarin cursussen in eigen tijd worden gevolgd.

\subsection{Kwalitatieve en kwantitatieve inzetbaarheid}

Naast het wervings- en selectiebeleid en het HRD beleid vormt de inzetbaarheid van het personeel ook een belangrijk onderdeel van het HRM beleid. Daarbij kan het gaan om de inzetbaarheid van apothekersassistenten op taken die strikt genomen niet tot de functie van de assistent behoren, bijvoorbeeld managementtaken of administratieve taken. Dit noemen we de kwalitatieve inzetbaarheid. Een andere

23. Zie: A. De Grip en I.J.P. Sieben (2002). Werken in de openbare apotheek, ROA-R-2002, Maastricht. 
manier om de bezetting van de apotheek te verbeteren is het vergroten van de kwantitatieve inzetbaarheid van de medewerkers. Bijvoorbeeld door de apothekersassistenten meer uren te laten werken (overuren te laten maken), zodat minder nieuwe apothekersassistenten hoeven worden geworven en niettemin de bezetting van de apotheek gewaarborgd is. Ook het schuiven met de werktijden van het personeel om op die manier bezettingsproblemen op te lossen noemen we kwantitatieve inzetbaarheid.

In deze paragraaf wordt een beeld geschetst van de mate waarin apotheken tot nu toe gebruik maken van de kwantitatieve en de kwalitatieve inzetbaarheid van de apothekersassistenten om knelpunten in de personeelsvoorziening te beperken.

\section{Kwalitatieve inzetbaarheid}

Figuur 4.8 laat zien dat apothekersassistenten over het algemeen ook worden ingezet op taken die van origine niet tot hun takenpakket behoren. Ruim $60 \%$ van de apothekers zet de assistenten in op andere taken. 25\% Van de apothekers zet de assistenten alléén in op managementtaken. Bijna 15\% van de apotheken laat de assistenten behalve managementtaken ook taken overnemen die normaal gesproken tot een lagere functie behoren. Daarmee is de inzetbaarheid van de assistenten in deze apotheken wat beter. In slechts $6 \%$ van de apotheken nemen assistenten alle soorten taken over: zowel farmaceutische taken, als managementtaken als taken van lagere functies.

In de zelfstandige apotheken doet de apotheker wat minder vaak een beroep op de brede inzetbaarheid van de assistenten dan in grote apotheekgroepen. Opvallend is verder dat assistenten in de grote apotheekgroepen relatief vaak worden ingezet op taken die normaal gesproken tot een lagere functie behoren óf op managementtaken. Dat assistenten worden ingezet op zowel management als lagere functietaken komt in grote apotheekgroepen minder vaak voor dan in kleine apotheekgroepen en zelfstandige apotheken. Dit geeft aan dat in grote apotheekgroepen in feite sprake is van een grotere mate van functiedifferentiatie onder apothekersassistenten dan in andere apotheken.

In de regio's met de grootste knelpunten in de personeelsvoorziening (Noordwest en Middenwest) is de inzetbaarheid van de apothekersassistenten niet groter dan in andere regio's. Het is zelfs zo dat de assistenten in de regio Noord het vaakst op alle drie de taakgebieden worden ingezet, terwijl dit juist de regio is waar de knelpunten het minst groot zijn. Bijna $20 \%$ van de apothekers in deze regio geeft aan assistenten zowel op farmaceutische taken, als op managementtaken als op taken van een lagere functie in te zetten. In andere regio's is dat nog geen 10\%. Met name de inzet van assistenten op farmaceutische taken is kenmerkend voor de regio Noord. Dit zou erop kunnen wijzen dat knelpunten in de personeelsvoorziening er juist toe leiden dat apothekers ernaar streven dat apothekersassistenten zich sterker richten op hun kerntaken. Voor andere werkzaamheden worden dan bijvoorbeeld mensen aangetrokken met een andere opleidingsachtergrond. 


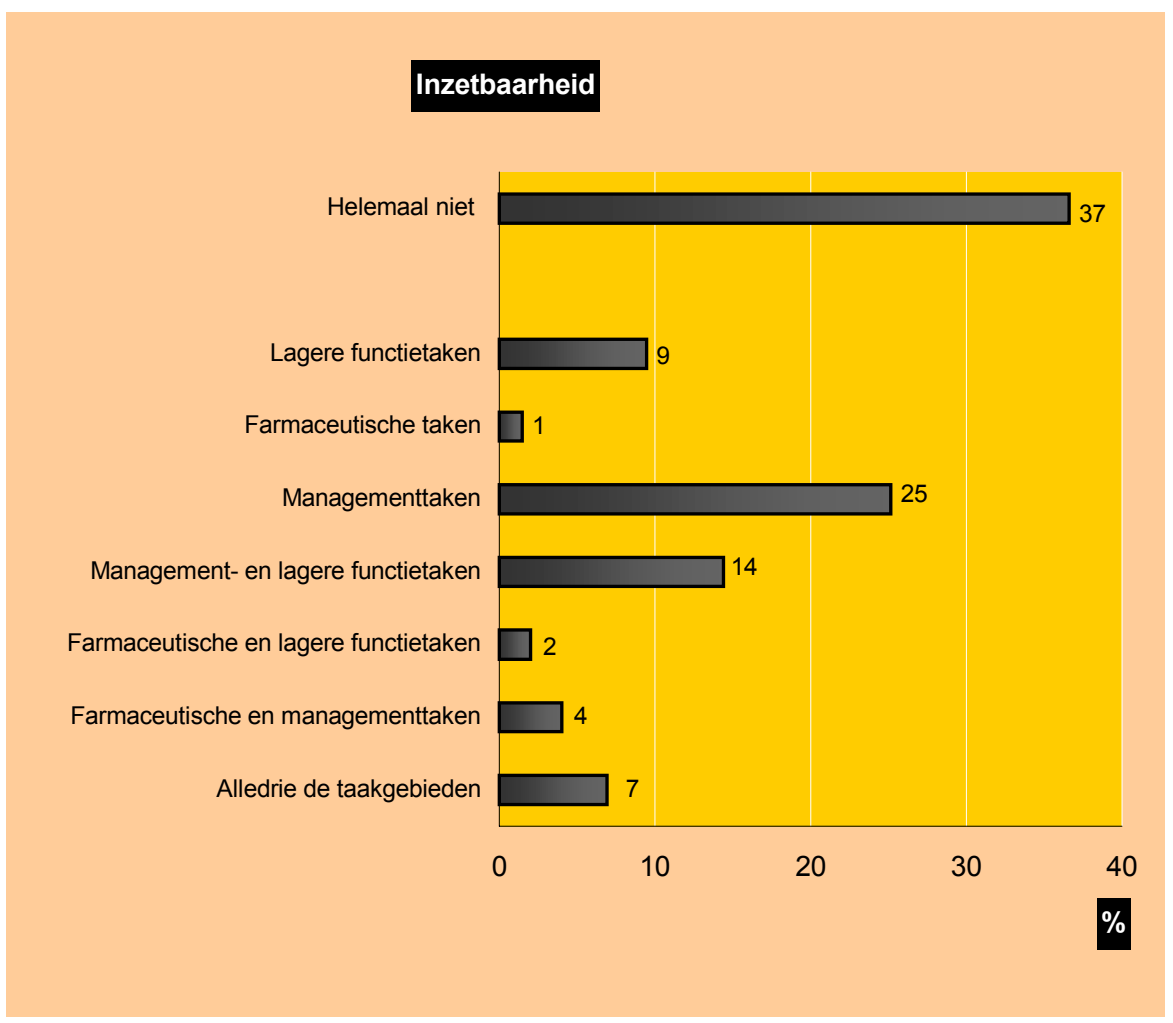

Bron: ROA/SFK

In de regio Zuidwest doet niet meer dan de helft van de apothekers een beroep op de brede inzetbaarheid van de assistenten. In andere regio's ligt dat percentage zo'n 15\%-punt hoger. Eerder bleek ook al dat apothekers in de regio Zuidwest minder vaak aangeven dat horizontale en verticale functiedifferentiatie een belangrijke bron van verandering voor de werkzaamheden van de apothekersassistenten is.

In de (erg) grote apotheken wordt het vaakst een beroep gedaan op de inzetbaarheid van de apothekersassistenten. Vooral managementtaken en farmaceutische taken worden in de erg grote apotheken relatief vaak door apothekersassistenten overgenomen. Managementtaken worden in kleine apotheken minder vaak door de assistenten uitgevoerd. Deze resultaten bevestigen het eerder gegeven beeld dat apothekers in grotere apotheken juist verticale functiedifferentiatie als belangrijke verandering in het werk van de assistenten zien. 


\section{Kwantitatieve inzetbaarheid: overwerk ${ }^{24}$}

Figuur 4.9 geeft een overzicht van de mate waarin apothekersassistenten meer uren werken dan in hun arbeidsovereenkomst is vastgelegd. In ongeveer driekwart van de apotheken komt het voor dat assistenten overwerken, maar in de meeste gevallen is dat overwerk niet structureel.

Figuur 4.9

Percentage apotheken waarin apothekersassistenten overwerken, 2001

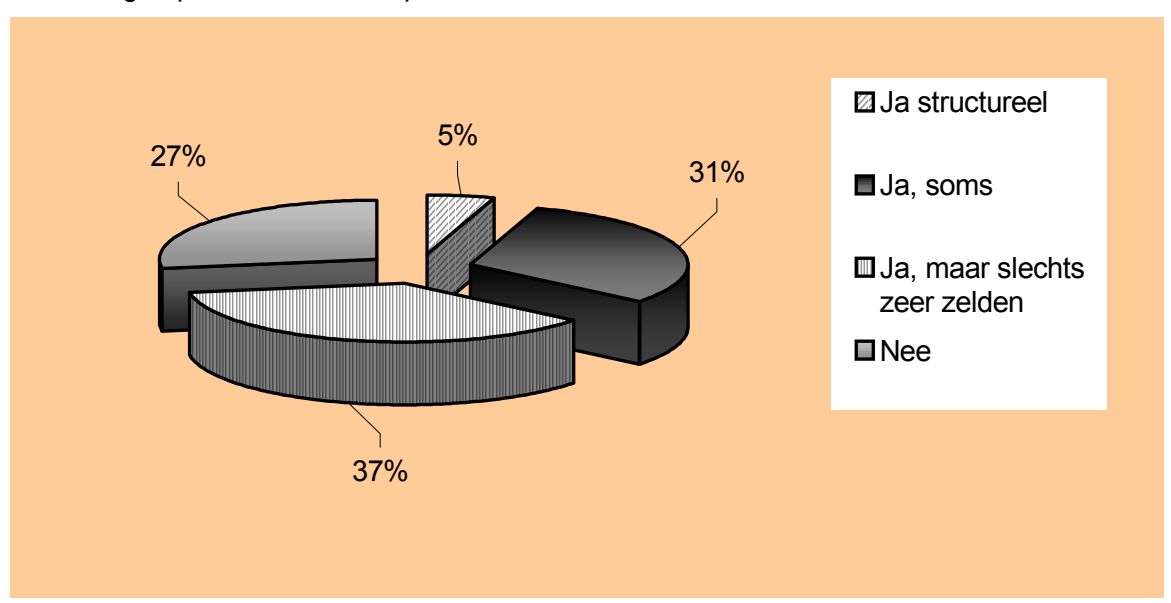

\section{Bron: ROA/SFK}

Overwerk komt wat meer voor in de grote apotheekgroepen (5 of meer apotheken) dan in de kleine apotheekgroepen (minder dan 5 apotheken) en de zelfstandige apotheken. Het overwerk is echter ook in de grote apotheekgroepen niet structureel. Grote apotheekgroepen scoren alleen opvallend hoger als het gaat om overwerk dat zelden tot soms voorkomt.

Structureel overwerk komt wat vaker voor in de regio's Zuidoost en Middenwest dan in andere regio's. Vooral voor de regio Middenwest kan de oorzaak liggen in de hoge vacaturegraad, waardoor apothekers de kwantitatieve inzetbaarheid van de assistenten aangrijpen om de bezetting van de apotheek te waarborgen. In de regio Noordwest, ook een regio met een hoge vacaturegraad en relatief grote knelpunten in de personeelsvoorziening, komt overwerk echter juist veel minder vaak voor. Bovendien wordt in de regio Noord juist relatief veel overwerk verricht, terwijl dit de regio is met de minste knelpunten. Wel is in de regio Noord de werkdruk aan de hoge kant. Dat kan samenhangen met de hoge mate waarin wordt overgewerkt.

Naarmate er meer assistenten werkzaam zijn binnen een apotheek neemt de mate waarin overwerk wordt verricht toe. Structureel overwerk komt echter nauwelijks voor. Niet in kleine en ook niet in grote apotheken. Het lijkt er dus op dat overwerk niet als middel wordt aangegrepen om knelpunten in de personeelsvoorzieining op te lossen.

24. Het gaat hierbij om de vraag of apothekersassistenten wel eens meer uren werken dan in de arbeidsovereenkomst is vastgelegd. 
Behalve het laten verrichten van overwerk kan de apotheker in geval van bezettingsproblemen ook schuiven met (de werktijden van) apothekersassistenten. In figuur 4.10 wordt aangegeven in hoeverre dat in de openbare apotheek gebeurt. Er wordt door maar liefst $93 \%$ van de apothekers inderdaad geschoven met (de werktijden van) het personeel om bezettingsproblemen op te lossen. Dat gebeurt in de meeste apotheken echter niet structureel. In de apotheken die deel uitmaken van een grote apotheekgroep komt het structureel schuiven met (de werktijden van) personeel wel wat vaker voor dan in zelfstandige of apotheken die deel uitmaken van een kleine apotheekgroep. Het feit dat voor de grote apotheekgroepen de knelpunten op de arbeidsmarkt wat groter zijn dan in de kleinere apotheekgroepen zou een verklaring kunnen zijn voor het gevonden verschil.

Figuur 4.10

Percentage apotheken waarin vanwege bezettingsproblemen wordt geschoven met (de werktijden van) het personeel, 2001

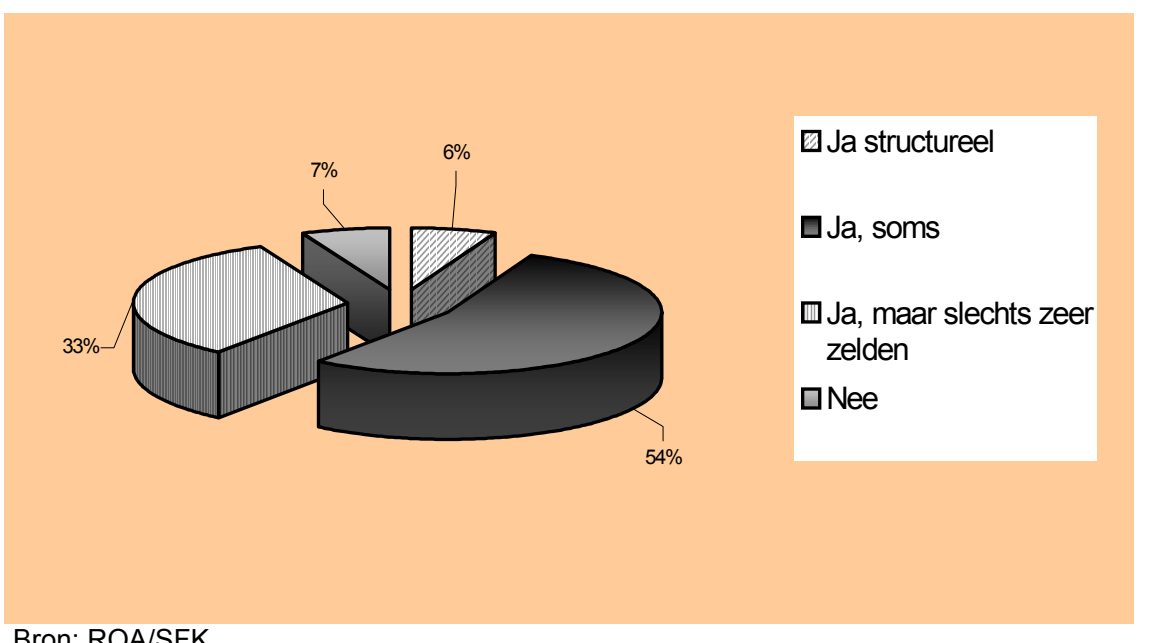

De relatief grote knelpunten in de personeelsvoorziening voor apothekers in de regio Middenwest vormen waarschijnlijk ook een verklaring voor het feit dat in deze regio wat meer geschoven wordt met (de werktijden van) het personeel. Dat er in de regio's met de meeste knelpunten ook meer met (de werktijden van) personeel geschoven wordt, blijkt ten slotte ook uit het percentage apotheken dat dit structureel doet. Dat percentage is het hoogst in de drie regio's met de hoogste vacaturegraad: Noordwest, Middenwest en Zuidoost.

De omvang van de apotheek doet niet zo heel veel ter zake als het gaat om het schuiven met (de werktijden van) personeel, zij het dat apothekers in de kleine apotheken wat minder schuiven met werktijden van het personeel dan apothekers van grotere apotheken. In kleine apotheken gebeurt dat schuiven echter wel iets structureler. Het verschil is echter niet significant. 


\subsection{Arbeidsvoorwaardenbeleid ${ }^{25}$}

Als vierde en laatste onderdeel van het HRM beleid wordt in deze paragraaf nader ingegaan op het arbeidsvoorwaardenbeleid dat binnen de apothekersbranche wordt gevoerd. Het arbeidsvoorwaardenbeleid is gericht op het creëren van een prettig en stimulerend werkklimaat binnen de apotheek. Bovendien gaat van een aantrekkelijk arbeidsvoorwaardenbeleid een aanzuigende werking uit naar potentiële werknemers.

\section{Figuur 4.11}

Percentage apotheken dat bepaalde faciliteiten en regelingen aanbiedt, 2001

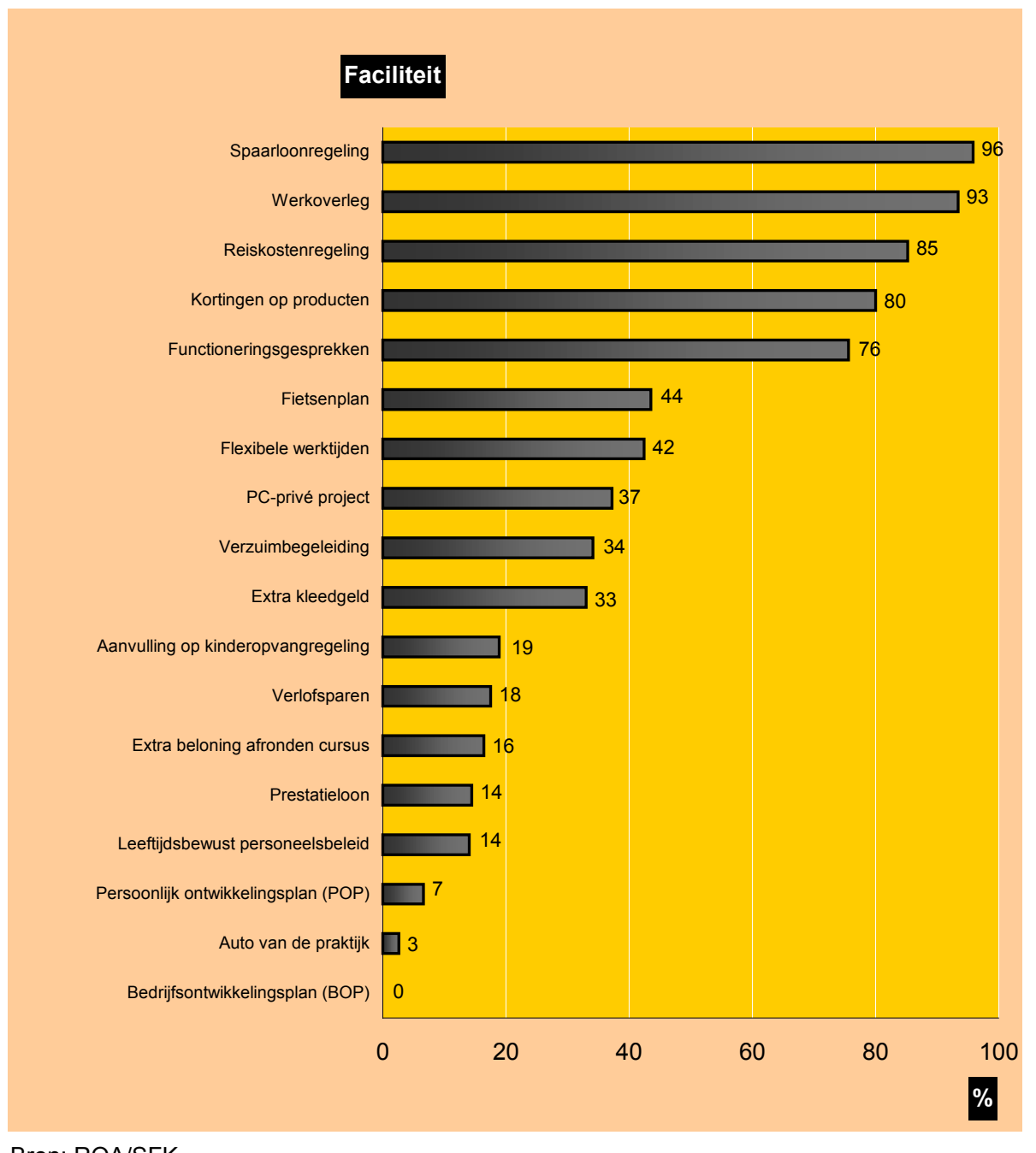

Bron: ROA/SFK

25. Veel van de besproken arbeidsvoorwaarden zijn in de CAO vastgelegd. Dat geldt bijvoorbeeld voor functioneringsgesprekken, kinderopvang en kortingen op producten. 
In figuur 4.11 wordt een overzicht gegeven van de faciliteiten en regelingen die in de apotheken worden aangeboden. Hieruit blijkt dat in de apothekersbranche veel aandacht bestaat voor 'klassieke' secundaire arbeidsvoorwaarden als reiskostenregelingen en kortingen op producten die men verkoopt. Het meest is er echter aandacht voor spaarloonregelingen. Daarnaast is er in veel apotheken aandacht voor het persoonlijk functioneren van de apothekersassistenten, is er veel aandacht voor de onderlinge samenwerking, wordt in veel apotheken werkoverleg gepleegd en vinden veel functioneringsgesprekken plaats.

Persoonlijke en Bedrijfsontwikkelingsplannen ${ }^{26}$ zijn, waarschijnlijk mede vanwege de knelpunten in de personeelsvoorziening, de hoge werkdruk en de opbouw van de apothekersbranche (veel kleinere bedrijven), nog nauwelijks geïntroduceerd. Persoonlijke ontwikkelingsplannen worden in slechts $7 \%$ van de apotheken opgesteld, bedrijfsontwikkelingsplannen zelfs helemaal niet. Dit lage percentage wekt enige verbazing gezien de kosten die gemaakt worden voor bij- en nascholing.

Ook andere vormen van beleid gericht op het duurzaam inzetbaar houden van assistenten, zoals een leeftijdsbewust personeelsbeleid of verzuimbegeleiding worden slechts door een minderheid van de apothekers gevoerd.

In apotheken die tot een grote apotheekgroep behoren worden over het algemeen wat meer faciliteiten geboden dan in andere apotheken. Vooral de aanvulling op de kinderopvangregeling, extra kleedgeld en het PC-privé project worden wat vaker genoemd. Zelfstandige apotheken en apotheken die tot een groep met minder dan 5 apotheken behoren houden zich wel wat meer bezig met verzuimbegeleiding en leeftijdsbewust personeelsbeleid dan grote apotheekgroepen.

De apothekers in de regio Noordwest bieden de meeste faciliteiten. Apothekers in de regio Middenwest opvallend genoeg de minste. Dit zijn precies de twee regio's waarvoor geldt dat de knelpunten in de personeelsvoorziening het grootst zijn. Blijkbaar zijn apothekers in de regio Middenwest er heel wat minder van overtuigd dat het bieden van een aantrekkelijk arbeidsvoorwaardenpakket de problemen die zij hebben met het vervullen van vacatures zou kunnen oplossen.

Apothekers in de regio's Noordwest en Middenwest besteden iets meer aandacht aan leeftijdsbewust personeelsbeleid en de mogelijkheden om op flexibele werktijden te werken. In de regio Noordwest wordt bovendien naar verhouding veel aandacht besteed aan aanvullingen op de bestaande kinderopvangregeling en aan het voeren van functioneringsgesprekken.

Apotheken in de regio Noord zijn weliswaar niet zo heel actief voor wat betreft het aanbieden van aantrekkelijke arbeidsvoorwaarden, maar POP's worden er relatief veel opgesteld. In de regio Noord is de apotheker bovendien actiever bij het aanbieden van PC-privé projecten dan in andere regio's. Vooral de regio Middenwest blijft

26. Het betreft hier persoons- of bedrijfsgebonden ontwikkelings- of leerplannen, die jaarlijks worden besproken met de apotheker. 
wat dit betreft ver achter. Apothekers in de regio Middenwest zijn bovendien het zuinigst met het aanbieden van reiskostenregelingen, verlofspaarregelingen en spaarloonregelingen. Verzuimbegeleiding wordt ten slotte ook minder aangeboden in de regio Middenwest dan in andere regio's. Het feit dat het verzuimpercentage in de regio Middenwest het laagst is, is hiervoor mogelijk een verklaring.

De omvang van de apotheek doet voor wat betreft de aangeboden arbeidsvoorwaarden niet zo ter zake. Grote apotheken bieden over het algemeen wat meer faciliteiten dan kleine apotheken. Een uitzondering vormt het geven van kortingen op producten.

\subsection{HRM beleid gericht op het onbenutte arbeidspotentieel}

Gezien de mate waarin knelpunten zich voordoen in de apothekersbranche en de omvang van het onbenutte arbeidspotentieel voor de branche is het interessant een beeld te krijgen van de mate waarin apotheken op dit moment in staat zijn datgene te bieden dat potentiële herintreders over de streep kan trekken om hun oude beroep weer te gaan uitoefenen.

Een belangrijke reden voor apothekersassistenten om niet als apothekersassistenten in de openbare apotheek te werken is de zorg voor kinderen. ${ }^{27}$ Dat betekent echter niet automatisch dat assistenten stoppen vanwege een te beperkte kinderopvang. Géén van de assistenten die waren gestopt met werken deed dat omdat de faciliteiten voor kinderopvang te beperkt waren. Kennelijk stond hun keuze om voor hun kind(eren) te gaan zorgen los van de mogelijkheden voor kinderopvang. Echter, voor ruim $10 \%$ van het huidige onbenutte arbeidspotentieel vormen de beperkte faciliteiten voor kinderopvang of buitenschoolse opvang wel een reden om niet weer als apothekersassistent in de openbare apotheek te gáán werken. Het aanbieden van aanvullingen op de bestaande CAO-regelingen ten aanzien van de kinderopvang zou deze potentiële herintreders daarom wel eens een stimulans kunnen geven weer als apothekersassistent te gaan werken.

Twee andere redenen voor assistenten om te stoppen zijn het te beperkte salaris en de beperkte mogelijkheden om met flexibele werktijden te werken. De mogelijkheid om in flexibele werktijden te werken bestaat tot nu toe in niet meer dan $42 \%$ van de apotheken, zoals bijvoorbeeld ook in de ziekenhuiszorg is gebleken kan de introductie van flexibele werktijden een stimulans zijn om een deel van de potentiële herintreders met kinderen die naar de basisschool gaan weer naar de apotheek te halen.

Het bieden van een hoger salaris is waarschijnlijk ook een goed middel om potentiële herintreders over de streep te trekken. Overigens vindt slechts $10 \%$ van de apothekers de té hoge salariseisen van potentiële werknemers een probleem bij de werving. Daartegenover staat dat $12 \%$ van de apothekers best bereid is het salaris te verhogen om meer herintreders in dienst te kunnen nemen.

27. Zie F.Cörvers, B.J. Diephuis en B. Golsteyn (2002), Het onbenutte arbeidspotentieel van apothekersassistenten in de openbare apotheek, ROA-R-2002/2, Maastricht. 
Omdat naast het salaris ook het beperkte carrièreperspectief het negatieve beeld van de opleiding versterkt, is het ook van belang dat er binnen apotheken meer structurele aandacht wordt besteed aan communicatie over ambities, loopbaanperspectieven en -wensen. Dat kan in functioneringsgesprekken, die in ruim $75 \%$ van de apotheken reeds plaatsvinden, maar beter is het om door middel van persoonlijke ontwikkelingsplannen (POP) de ontwikkeling, ambitie en bijvoorbeeld vorderingen van de assistenten te volgen en terug te koppelen. Dat schept voor zowel de apotheker als voor de assistent duidelijkheid omtrent de carrièreperspectieven. Het opstellen van POP's gebeurt in de apothekersbranche nog nauwelijks. Slechts $7 \%$ van de apothekers heeft POP's opgesteld. Ook hier ligt dus een belangrijk punt van verbetering. Niet alleen naar het onbenutte arbeidspotentieel toe maar zeker ook voor het zittende personeel. Ruim $15 \%$ van de vertrokken apothekersassistenten is immers vertrokken omdat de perspectieven buiten de branche beter waren. 



\section{Effecten van HRM beleid}

\subsection{Inleiding}

In het vorige hoofdstuk is het Human Resource Management (HRM) beleid in de openbare apotheek in beeld gebracht. Daarbij is een onderscheid gemaakt tussen het beleid op het gebied van werving en selectie, het Human Resource Development beleid, het beleid gericht op de inzetbaarheid van apothekersassistenten en het arbeidsvoorwaardenbeleid in de openbare apotheek. In dit hoofdstuk wordt geprobeerd de effecten van deze vier facetten van het HRM beleid op een viertal terreinen te onderzoeken. Van een goed HRM beleid zou immers een aantal effecten op het gebied van knelpunten in de openbare apotheek (zie hoofdstuk 3) verwacht mogen worden. Daarbij kan men denken aan het gemakkelijker kunnen aantrekken van personeel en het verminderen van het personeelsverloop. Daarnaast zou een goed HRM beleid de werkdruk en het ziekteverzuim kunnen verminderen en zo mogelijk de productiviteit kunnen verhogen.

Om de effecten van het gevoerde HRM beleid op deze knelpuntterreinen in kaart te brengen worden analyses uitgevoerd waarbij de vier facetten van dit beleid onderzocht worden. Hierbij wordt ook rekening gehouden met enkele belangrijke andere kenmerken van apotheken, zoals het soort apotheek, de apotheekgrootte en de regio waar de apotheek is gevestigd. Daarnaast wordt nagegaan of er belangrijke technologische of organisatorische veranderingen in de apotheek hebben plaatsgevonden en worden personeelskenmerken als de gemiddelde leeftijd van de apothekersassistenten, hun ervaring in de huidige functie, salaris, gemiddelde competentieniveau en het percentage apothekersassistenten met een tijdelijk contract in de analyses betrokken.

Het bepalen van de effecten van het gevoerde HRM beleid is niet eenvoudig. Wanneer een apotheker bijvoorbeeld aangeeft een specifiek HRM instrument in te hebben gezet dat de werving van nieuwe medewerkers bevordert, en deze apotheker heeft te maken met geringe knelpunten in de personeelsvoorziening, dan zouden we kunnen concluderen dat het HRM beleid gewerkt heeft. Andersom geldt echter ook dat juist de apothekers die te kampen hebben met moeilijk vervulbare vacatures, meer actie ondernemen om hun personeelsproblematiek te verminderen. Het HRM beleid is dan niet zozeer de oorzaak, maar veeleer het gevolg van de knelpunten in de personeelsvoorziening in de desbetreffende openbare apotheek. Om te onderzoeken of dit HRM beleid echt leidt tot een geringere vacatureproblematiek in de openbare apotheek zullen de apothekers over een of twee jaar opnieuw bevraagd dienen te worden over hun knelpunten. HRM beleid heeft immers enige tijd nodig om effecten te sorteren. Dit laatste geldt overigens niet alleen voor de effecten op de vacatureproblematiek, maar ook voor de effecten van het HRM beleid op het personeelsverloop, de werkdruk, het ziekteverzuim en de productiviteit van apothekersassistenten. 
De opbouw van dit hoofdstuk is als volgt. In paragraaf 5.2 worden de effecten van het gevoerde HRM beleid op de vacatureproblematiek in de openbare apotheek onderzocht. Zorgen inspanningen op het gebied van HRM beleid ervoor dat er minder vacatures voor apothekersassistenten openstaan? Ook wordt er in deze paragraaf gekeken naar de duur van de openstaande vacatures voor apothekersassistenten. Worden openstaande vacatures vanwege specifieke HRM inspanningen sneller opgevuld?

Daarna wordt in paragraaf 5.3 de relatie tussen het HRM beleid en het personeelsverloop in de openbare apotheek onderzocht. Leidt het gevoerde HRM beleid ertoe dat er minder assistenten uit de apotheek vertrekken? Of anders gezegd, heeft het gevoerde HRM beleid een effect op de uitstroom van apothekersassistenten in de openbare apotheek?

Paragraaf 5.4 beschrijft de invloed van het gevoerde HRM beleid op de werkdruk en het ziekteverzuim van apothekersassistenten. Uit hoofdstuk 3 bleek dat de werkdruk onder apothekersassistenten door de apothekers als vrij hoog ervaren wordt en vaak tot personeelsverloop leidt. Een goed HRM beleid zou deze werkdruk moeten verminderen. Daarnaast zou dit beleid mogelijk ook het ziekteverzuim onder apothekersassistenten kunnen terugdringen. Dit laatste vermindert niet alleen de verzuimkosten, maar draagt ook bij aan een vermindering van de werkdruk.

In paragraaf 5.5 worden de effecten van het HRM beleid op de productiviteit in de openbare apotheek onderzocht. Het is vrij moeilijk om deze productiviteit te meten, maar het gemiddelde aantal verwerkte receptregels per apothekersassistent op basis van een fulltime werkweek van 36 uur is waarschijnlijk een goede indicator.

Ten slotte worden in paragraaf 5.6 enkele concluderende opmerkingen gemaakt.

\subsection{HRM beleid en vacatures in de openbare apotheek}

In deze paragraaf wordt onderzocht of het gevoerde HRM beleid vruchten afwerpt wanneer het gaat om de vacatureproblematiek voor apothekersassistenten in de openbare apotheek. Hoofdstuk 3 liet zien dat het aantal openstaande vacatures voor apothekersassistenten aanzienlijk is, met name in de Randstad. Ook staan deze vacatures lang open, gemiddeld zo'n 6 maanden. Welke aspecten van het HRM beleid leiden ertoe dat het aantal vacatures vermindert en dat daarnaast de duur van de openstaande vacatures teruggedrongen wordt?

Allereerst mag verwacht worden dat het beleid rond de werving en selectie een belangrijke rol kan spelen bij het sneller opvullen van vacatures. Het is daarom belangrijk de initiatieven die door werkgevers in de farmaceutische zorg genomen zijn om vacatures op te vullen nader te onderzoeken. Het betreft hier maatregelen als het aantrekken van assistenten met een andere opleidingsachtergrond, het om- of bijscholen van zittende werknemers, het verlagen van de opleidings- of ervaringseisen, het bieden van een hoger salaris of andere, CAO-overstijgende arbeidsvoorwaarden, het inschakelen van het Arbeidsbureau (CWI), het uitbesteden van werk en 
het actiever benaderen van scholieren. Daarnaast kijken we ook naar de voorkeur van de apotheker om een schoolverlater aan te nemen. Een grotere voorkeur voor schoolverlaters kan er immers toe leiden dat het moeilijker wordt om een vacature (snel) op te vullen. Ook kijken we of apothekers door het aantrekken van stagiaires en het geven van vergoedingen aan deze stagiaires de problemen rondom de werving van apothekersassistenten weten te verminderen.

De vacatureproblematiek waarmee een apotheker geconfronteerd wordt, hoeft niet alleen door het wervings- en selectiebeleid beïnvloed te worden. Het gevoerde human resource development beleid zou ook een invloed kunnen hebben op de vacaturegraad en de duur van de openstaande vacatures. Apothekers, die hun assistenten stimuleren om zich verder te ontwikkelen door cursussen te volgen, zijn mogelijk aantrekkelijker voor nieuwe apothekersassistenten dan apothekers die hiervoor minder faciliteiten bieden. Apothekers zouden er hierdoor beter in kunnen slagen hun openstaande vacatures op te vullen.

In de derde plaats zou het flexibel inzetten van apothekersassistenten het aantal vacatures in de openbare apotheek kunnen terugdringen. Het aantal openstaande vacatures zou mogelijk beperkt kunnen worden door assistenten werkzaamheden te laten uitvoeren die niet tot hun functie behoren maar wel de functie verrijken (kwalitatieve inzetbaarheid). Anderzijds zou het breed inzetten van apothekersassistenten kunnen leiden tot grotere tekorten, met name wanneer assistenten veel werkzaamheden beneden hun niveau moeten verrichten. Knelpunten in de personeelsvoorziening zouden ook kunnen worden verminderd door de assistenten te laten overwerken of door met hun werktijden te schuiven (kwantitatieve inzetbaarheid). Op de duur van de openstaande vacatures zal dit facet van het HRM beleid waarschijnlijk geen invloed uitoefenen.

Ten slotte zou het arbeidsvoorwaardenbeleid zijn weerslag kunnen hebben op de vacatureproblematiek in de openbare apotheek. Werkgevers zouden de slag om personeel mogelijk eerder kunnen winnen door betere faciliteiten en regelingen aan hun medewerkers aan te bieden dan de concurrentie binnen en buiten de branche. Hierbij moet gedacht worden aan zaken als een hoger salaris, reiskostenregeling, aanvullingen op de kinderopvangregeling in de CAO, korting op producten, een persoonlijk ontwikkelingsplan (POP), functioneringsgesprekken, prestatiebeloning, verzuimbegeleiding en flexibele werktijden.

\section{Vacaturegraad}

Schema 5.1 geeft een samenvatting van de belangrijkste effecten van HRM beleid op het aantal vacatures dat openstaat in de openbare apotheek (de vacaturegraad). Hierbij moet opgemerkt worden dat vacatures om twee redenen kunnen ontstaan: omdat vertrokken personeel vervangen moet worden en omdat er sprake is van een toename van de hoeveelheid werk in de apotheek. Uit hoofdstuk 3 bleek dat het aantal vacatures voortkomend uit een vraag naar vervanging veel groter is dan het aantal vacatures dat door groei van de apotheek tot stand komt. 
Schema 5.1 laat zien dat met name enkele aspecten van het arbeidsvoorwaardenbeleid in de openbare apotheek belangrijk zijn. In apotheken waar functioneringsgesprekken gehouden worden en flexibele werktijden aangeboden worden zijn er minder openstaande vacatures. Het houden van functioneringsgesprekken zou daarbij overigens in algemene zin een indicatie kunnen zijn van de zorg die men aan het welbevinden en de ontplooiingsmogelijkheden van het personeel besteed. Assistenten werken het liefst in deeltijd, en wel zo dat dit te combineren is met eventuele zorgtaken. Dit maakt waarschijnlijk ook de apotheken die veel uren per dag open zijn aantrekkelijk voor herintreders, want ook deze apotheken kennen minder vacatures. ${ }^{28}$ Daarnaast hebben de apotheken die deel uitmaken van een kleine apotheekgroepen met minder grote vacatureproblemen te kampen (zie ook hoofdstuk 3).

\section{Schema 5.1}

HRM beleid en de vacaturegraad voor apothekersassistenten in de openbare apotheek, 2001

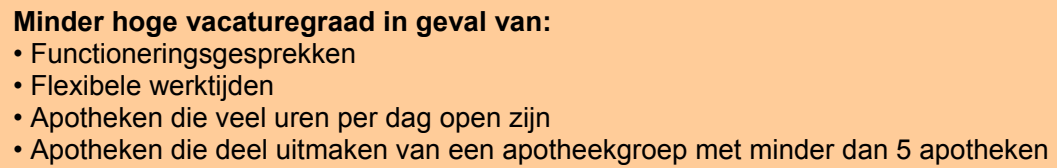

Meer problemen met het opvullen van vacatures zijn er voor de apothekers die hun assistenten taken uit lagere functies laten verrichten en voor apothekers die aan prestatiebeloning doen. Wellicht zijn deze maatregelen niet populair onder (potentiële) apothekersassistenten. Tevens kennen de apotheken in de regio's Middenwest en Zuidoost en apotheken met weinig werknemers een hoge vacaturegraad. Dit kwam ook in hoofdstuk 3 naar voren. Daar werd ook de regio Middenwest als een probleemgebied genoemd, maar dit regionale verschil lijkt te verdwijnen wanneer rekening gehouden wordt met het gevoerde HRM beleid en allerlei apotheekkenmerken als soort apotheek, apotheekomvang en personeelsopbouw van de apotheek. Dit betekent dat de vacatureproblematiek in de regio Middenwest niet zozeer een

28. Het is echter ook mogelijk dat apotheken met een hoge vacaturegraad hierop reageren door hun openingstijden te verkorten vanwege het tekort aan personeel. Men zou in dat geval echter wel verwachten dat dit de personeelsproblematiek enigszins zou verlichten. Dit laatste is echter vooralsnog niet het geval.

64 
regionale problematiek is, maar veeleer een gevolg van apotheekkenmerken en een minder effectief HRM beleid.

Daarnaast blijkt uit schema 5.1 dat een aantal HRM instrumenten vooral in de openbare apotheek worden ingezet wanneer er sprake is van een hoge vacaturegraad. Het gaat dan om het aantrekken van hoger opgeleiden, het verlagen van de opleidings- en ervaringseisen bij het aantrekken van nieuw personeel en het inschakelen van het arbeidsbureau. Of dergelijk HRM beleid, dat vooral gericht is op de werving en selectie van apothekersassistenten, effectief is, zal uit toekomstig onderzoek moeten blijken.

\section{Duur van openstaande vacatures}

Naast het aantal vacatures, is het ook van belang te kijken naar de lengte van de periode dat deze vacatures open staan. Uit schema 5.2 blijkt dat apotheken die veel uren per dag open zijn, niet alleen minder vacatures te hebben, maar deze ook sneller te kunnen opvullen. Dit lijkt misschien op het eerste oog vreemd, omdat veelal gedacht wordt dat werken in de avonduren of weekenden onaantrekkelijk gevonden wordt. Zoals reeds eerder opgemerkt werd, bieden deze werktijden echter waarschijnlijk ook mogelijkheden voor mensen met zorgtaken om in deeltijd te gaan werken. Daarnaast staan in apotheken waar de ervaringseisen verlaagd zijn, vacatures minder lang open. Opvallend is dat het arbeidsvoorwaardenbeleid in de openbare apotheek geen significant effect heeft op de duur van de openstaande vacatures. Dit zou kunnen komen omdat apothekers er niet in slagen de relatief gunstige arbeidsvoorwaarden die zij bieden kenbaar te maken naar (potentiële) sollicitanten. Mogelijk ligt hier een taak voor de apothekers om dit beleid meer naar buiten te brengen en te promoten.

Ten slotte laat schema 5.2 zien dat apothekers het arbeidsbureau vaak pas inschakelen wanneer vacatures lang openstaan en moeilijk vervulbaar blijken te zijn. Wellicht proberen zij eerst via andere kanalen aan nieuw personeel te komen. Hoofdstuk 4 liet zien dat met name het plaatsen van advertenties, het inschakelen van het eigen netwerk en het benaderen van scholen veel gebruikte wervingskanalen zijn. Ook blijken apothekers bij lang openstaande vacatures nogal eens de opleidingseisen van sollicitanten te verlagen.

\section{Schema 5.2}

HRM beleid en de duur van openstaande vacatures voor apothekersassistenten in de openbare apotheek, 2001

Minder lang openstaande vacatures in geval van:

- Apotheken die veel uren per dag open zijn

- Verlagen van de ervaringseisen

HRM beleid dat vooral ingezet wordt bij lang openstaande vacatures:

- Inschakelen van arbeidsbureau

- Verlagen van de opleidingseisen

Bron: ROA/SFK 


\subsection{HRM beleid en personeelsverloop in de openbare apotheek}

Het gevoerde HRM beleid zou ook een belangrijke bijdrage kunnen leveren aan het verminderen van de knelpunten in de personeelsvoorziening doordat het het personeelsverloop onder apothekersassistenten afremt. Hoofdstuk 3 toonde aan dat dit personeelsverloop behoorlijk hoog is, zeker in de regio's Noordwest en Middenwest. In deze paragraaf wordt daarom onderzocht welke effecten het gevoerde HRM beleid heeft op het percentage apothekersassistenten dat uit de apotheek vertrekt. Hierbij worden dezelfde vier facetten van het gevoerde HRM beleid als in de vorige paragraaf onder de loep genomen, met de volgende verwachtingen:

- De initiatieven die de apothekers ontplooien in het kader van de werving en selectie van nieuwe assistenten zullen waarschijnlijk geen directe invloed hebben op de uitstroom van apothekersassistenten.

- Apothekers, die hun assistenten in het kader van het human resource development beleid de mogelijkheid geven om cursussen te volgen, worden over het algemeen als aantrekkelijke werkgevers beschouwd. Apothekersassistenten zullen waarschijnlijk niet graag bij hen vertrekken, hetgeen tot een lager personeelsverloop zou kunnen leiden.

- Vanuit het oogpunt van de werkgever is het wellicht gunstig om apothekersassistenten flexibel in te zetten en soepel met hun werktijden en taken om te gaan. De keerzijde van de medaille is echter dat deze arbeidsomstandigheden over het algemeen minder gewaardeerd worden door het personeel, waardoor er mogelijk meer apothekersassistenten de apotheek uitstromen.

- Ten slotte mag verwacht worden dat apothekers die een goed arbeidsvoorwaardenbeleid voeren aantrekkelijke werkgevers zijn om bij te blijven werken. Daarom zou het aanbieden van goede faciliteiten en regelingen het personeelsverloop onder apothekersassistenten mogelijk kunnen verminderen.

Naast deze vier facetten van het HRM beleid worden ook hier weer de genoemde algemene kenmerken van openbare apotheken en hun personeel in de analyse betrokken. Schema 5.3 geeft de belangrijkste uitkomsten van deze analyse. Het blijkt dat apotheken die veel uren per dag open zijn, een lager personeelsverloop hebben. Deze apotheken blijken dus niet alleen aantrekkelijk te zijn voor nieuwe werknemers, maar ook voor het personeel dat al langer in de apotheek werkzaam is. Verder is het personeelsverloop laag in apotheken waar apothekersassistenten - gemiddeld gezien - al lang werken. Ook dit resultaat is niet zo vreemd; blijkbaar hebben assistenten het naar hun zin in deze apotheken en zien ze weinig reden om weg te gaan. Opvallender is de bevinding dat geen enkel facet van het HRM beleid de uitstroom van apothekersassistenten lijkt te verkleinen. Toch kan hieruit niet geconcludeerd worden dat HRM beleid geen enkele zin heeft. Schema 5.3 geeft namelijk aan dat juist de apothekers die geconfronteerd worden met een hoog personeelsverloop, hun HRM beleid intensiveren. Daarbij richt men zich opmerkelijk genoeg niet zozeer op het aantrekkelijk maken van het werk, maar veeleer op het vergemakkelijken van de werving van nieuw personeel door het aantrekken van medewerkers met een andere 
opleidingsachtergrond (bijvoorbeeld apotheekhulpen) en het verlagen van de opleidings- en ervaringseisen.

\section{Schema 5.3}

HRM beleid en het uitstroompercentage van apothekersassistenten in de openbare apotheek, 2001

Minder hoog uitstroompercentage in geval van:

- Apotheken die veel uren per dag open zijn

- Hoge gemiddelde baanduur van assistenten

Hoog uitstroompercentage in geval van:

- Hoog percentage assistenten met een tijdelijk contract of op oproepbasis

- Assistenten taken laten verrichten uit lagere functies

- Apotheken met minder dan 9 werknemers

HRM beleid dat vooral ingezet wordt bij een hoog uitstroompercentage:

- Aantrekken van anders opgeleiden

- Verlagen van de opleidingseisen

- Verlagen van de ervaringseisen

Bron: ROA/SFK

Ten slotte blijkt uit schema 5.3 dat het personeelsverloop groter is in apotheken waar veel assistenten met een tijdelijk contract of op oproepbasis werken. Dat assistenten met een tijdelijk contract vaker uit de openbare apotheek uitstromen mag als een vanzelfsprekendheid beschouwd worden. Blijkbaar wordt echter ook het werken op oproepbasis door assistenten niet als ideaal gezien en ruilt men een dergelijke baan, zeker bij een krappe arbeidsmarkt, veelal snel in voor een andere. Verder blijkt uit het onderzoek dat de uitstroom van apothekersassistenten hoger is wanneer zij werkzaamheden moeten verrichten die onder hun niveau liggen. Ten slotte is het personeelsverloop groter in apotheken met minder dan 8 werknemers.

\subsection{HRM beleid en werkdruk en ziekteverzuim in de openbare apotheek}

Naast de effecten van het gevoerde HRM beleid op de vacatureproblematiek en het personeelsverloop zijn er ook effecten te verwachten op de werkdruk van apothekersassistenten in de openbare apotheek. Deze werkdruk wordt, mede gezien de knelpunten in de personeelsvoorziening en de veranderingen die zich in de apotheek hebben voorgedaan, door de apothekers zelf als vrij hoog beschouwd (zie hoofdstuk 3). Daarnaast bleek uit hoofdstuk 2 dat het verzuimpercentage in de openbare apotheek op zo'n $8 \%$ ligt. Ook dit zou door goed ingezette HRM instrumenten teruggedrongen kunnen worden. Bij het bepalen van de effecten van het HRM beleid op de werkdruk en het ziekteverzuim van apothekersassistenten in de openbare apotheek worden weer de vier facetten van dit beleid als uitgangspunt genomen. Ditmaal met de volgende verwachtingen:

- Het wervings- en selectiebeleid zou ervoor kunnen zorgen dat er voldoende nieuwe assistenten worden aangetrokken om al het werk dat er in de openbare 
apotheek gedaan moet worden goed te verrichten. Dit zou kunnen leiden tot een lagere werkdruk en mogelijk, als gevolg daarvan, ook tot een lager ziekteverzuim.

- Wanneer apothekersassistenten in de openbare apotheek cursussen kunnen volgen, zullen zij wellicht beter over de benodigde kennis en vaardigheden beschikken om hun werk goed en efficiënt uit te voeren. Hierdoor zal de werkdruk in de openbare apotheek mogelijk verminderen en ook het ziekteverzuim teruggedrongen kunnen worden. Daarbij moet wel de kantekening gemaakt worden dat zeker wanneer de cursussen in werktijd gevolgd worden, dit de werkdruk weer kan verhogen.

- Door assistenten flexibel in te zetten, zowel qua taken als qua werktijden, zouden grote pieken in de werkdruk vermeden kunnen worden. Tegelijkertijd brengt deze flexibiliteit echter waarschijnlijk ook meer stress voor de assistenten met zich mee. Met name overwerk zou tot een hogere werkdruk en daarmee ook tot meer ziekteverzuim onder apothekersassistenten in de openbare apotheek kunnen leiden.

- Het arbeidsvoorwaardenbeleid zal waarschijnlijk geen grote invloed uitoefenen op de werkdruk en het ziekteverzuim. Wel is het zo dat door goede faciliteiten en regelingen te bieden, werknemers meer tevreden en gemotiveerder zijn, waardoor zij wellicht meer werkdruk aankunnen en minder snel ziek zijn.

\section{Werkdruk}

In schema 5.4 zijn de belangrijkste effecten van het HRM beleid op de werkdruk onder apothekersassistenten in de openbare apotheek in kaart gebracht. Allereerst valt op dat apothekersassistenten die werkzaam zijn in apotheken waar minder dan 80.000 receptregels verwerkt worden met een minder hoge werkdruk te kampen hebben (zie ook hoofdstuk 3).

Schema 5.4

HRM beleid en de werkdruk onder apothekersassistenten in de openbare apotheek, 2001

Minder hoge werkdruk in geval van:

- Apotheken met minder dan 80.000 verwerkte receptregels

Hoge werkdruk in geval van:

- Overwerk

- Assistenten taken laten verrichten uit lagere functies

HRM beleid dat vooral ingezet wordt bij een hoge werkdruk:

- Aantrekken van anders opgeleiden

- Bieden van een hoger salaris aan nieuwkomers

\section{Bron: ROA/SFK}

Er bestaat geen relatie tussen het volgen van cursussen, al dan niet door de SBA geaccrediteerd, en de werkdruk van apothekersassistenten. Wellicht heeft dit te maken met het feit dat cursussen op de korte termijn voornamelijk tijd en energie kosten. Dit zou het mogelijk positieve effect van deze cursussen op de werkdruk, 
namelijk het vergroten van de competenties van de assistenten en daardoor het vergroten van hun efficiëntie, teniet kunnen doen. Naast dit human resource development beleid, heeft ook het arbeidsvoorwaardenbeleid - zoals verwacht - geen significante invloed op de werkdruk in de openbare apotheek.

Het flexibel inzetten van assistenten hangt daarentegen duidelijk negatief samen met de werkdruk. De werkdruk van apothekersassistenten is hoger wanneer zij overwerken of taken uit lagere functies verrichten. Apothekers die te maken hebben met een dergelijke hoge werkdruk in hun apotheek, zijn echter wel bereid om hier iets aan te doen. Zij proberen wat vaker door het aantrekken van anders opgeleiden (bijvoorbeeld apotheekhulpen) toch in hun openstaande vacatures te voorzien om op deze manier de werkdruk te kunnen verminderen. Ook bieden zij nieuwkomers hogere salarissen ter compensatie aan.

\section{Ziekteverzuim}

Schema 5.5 toont dan de relatie tussen het HRM beleid en het ziekteverzuim onder apothekersassistenten in de openbare apotheek. Zoals al is opgemerkt in hoofdstuk 2, kennen zelfstandige apotheken of apotheken die tot een apotheekgroep van minder dan 5 apotheken behoren, een lager ziekteverzuim. Ook apotheken waar het gemiddelde competentieniveau van de assistenten - naar het oordeel van de apothekers - hoog is, hebben te maken met een minder hoog ziekteverzuim. Wellicht kunnen de meer competente apothekersassistenten hun werk beter aan, waardoor ze zich minder vaak ziek melden. Het human resource development beleid, dat gericht is op het vergroten van de competenties van assistenten middels cursussen, heeft echter geen direct effect op het ziekteverzuim in de openbare apotheek. Opvallend is verder dat apothekersassistenten die van hun werkgever korting op producten krijgen zich minder vaak ziek melden.

\section{Schema 5.5}

HRM beleid en het ziekteverzuim onder apothekersassistenten in de openbare apotheek, 2001

Minder hoog ziekteverzuim in geval van:

- Zelfstandige of apotheken die deel uitmaken van een kleine apotheekgroep

- Hoger gemiddeld competentieniveau van assistenten

- Korting op producten

Hoog ziekteverzuim in geval van:

- Prestatiebeloning

HRM beleid dat vooral ingezet wordt bij een hoog ziekteverzuim:

- Aantrekken van anders opgeleiden

- Bieden van een hoger salaris aan nieuwkomers

- Aanvullingen op kinderopvangregeling in de CAO

Bron: ROA/SFK

Het ziekteverzuim onder apothekersassistenten is hoger wanneer er sprake is van prestatiebeloning. Zo is het ziekteverzuim in apotheken met prestatiebeloning bijna 
$15 \%$, terwijl apotheken zonder prestatiebeloning een ziekteverzuim van $7 \%$ kennen. Dit zou erop kunnen wijzen dat assistenten die te maken hebben met deze vorm van beloning zich sneller opgejaagd voelen en zich daardoor eerder ziek melden. De maatregelen die apothekers treffen om een hoog ziekteverzuim onder apothekersassistenten tegen te gaan, zijn dezelfde maatregelen die zij inzetten om de werkdruk te verminderen. Het gaat dan om het verminderen van de vacatureproblematiek door het aantrekken van anders opgeleiden en het bieden van een hoger salaris, om op deze wijze de werkdruk voor de andere assistenten te verminderen. Daarnaast blijken apothekers die met een hoog ziekteverzuim kampen hun assistenten aanvullingen op de kinderopvangregelingen in de CAO aan te bieden. Dit zou erop kunnen wijzen dat dit verzuim mede het gevolg is van de problemen die apothekersassistenten ondervinden bij het combineren van werk en zorgtaken. De aanvullende regelingen maken het apothekersassistenten immers mogelijk om privé en werk beter te combineren. De effecten van deze maatregelen op het ziekteverzuim zullen echter uit toekomstig onderzoek moeten blijken.

\subsection{HRM beleid en productiviteit in de openbare apotheek}

Als laatste onderzoeken we of het gevoerde HRM beleid van invloed is op de productiviteit in de openbare apotheek. Productiviteit wordt hier uitgedrukt in het gemiddeld aantal verwerkte receptregels per apothekersassistent op basis van een fulltime werkweek van 36 uur. Dit is een zeer kwantitatieve 'economische' maat; aspecten die met de kwaliteit van de dienstverlening te maken hebben, blijven hier buiten beschouwing. Ook in deze paragraaf wordt gekeken naar de vier facetten van het HRM beleid, met de volgende verwachtingen:

- De relatie tussen het wervings- en selectiebeleid en de productiviteit in de openbare apotheek is niet zo duidelijk en verloopt vrij indirect. Wanneer apothekers door middel van dit beleid erin slagen de bezettingsproblemen in hun apotheek op te lossen, dan zal dit de productiviteit in hun apotheek mogelijk ten goede kunnen komen. Anderzijds kan het betekenen dat hetzelfde werk door minder assistenten verricht moet worden, waardoor op de korte termijn de productiviteit hoger is.

- Apothekersassistenten kunnen door het volgen van cursussen, hun competenties verbeteren. Zij zullen dan waarschijnlijk beter in staat zijn om hun werk goed en efficiënt uit te voeren. Vanuit een 'human capital' perspectief gezien, vergroot scholing dan ook de productiviteit van werknemers.

- De productiviteit zou wellicht ook verhoogd kunnen worden door apothekersassistenten flexibel in te zetten, zowel wat de taken die ze moeten verrichten als wat hun werktijden betreft. Deze kwalitatieve en kwantitatieve inzetbaarheid zou immers vanuit het oogpunt van de organisatie de efficiëntie kunnen vergroten.

- Ten slotte zou een goed arbeidsvoorwaardenbeleid de productiviteit mogelijk - op een indirecte wijze - kunnen verhogen. Door goede faciliteiten en regelingen aan te bieden, zou de motivatie van apothekersassistenten in de openbare apotheek kunnen toenemen, hetgeen productieverhogend kan werken. 
In schema 5.6 staan de belangrijkste effecten van het gevoerde HRM beleid op de productiviteit in de openbare apotheek. ${ }^{29}$ Wat in de eerste plaats duidelijk wordt is dat apotheken waarin assistenten ingezet worden om management taken als de administratie en personeelszaken uit te voeren, een minder hoge productiviteit hebben. Dit is vrij logisch, aangezien productiviteit hier gedefinieerd is als het gemiddeld aantal verwerkte receptregels per apothekersassistent. Een deel van de werktijd van de apothekersassistenten gaat dan immers op aan het verrichten van taken die doorgaans door de (tweede) apotheker verricht worden. De productiviteit is ook lager in de kleinere apotheken, zowel wat aantal verwerkte receptregels als wat aantal medewerkers betreft. Verder blijkt de productiviteit lager te zijn in apotheken waarin veel assistenten met een tijdelijk contract werken. Mogelijk zijn deze medewerkers minder betrokken bij de apotheek dan assistenten met een vast contract, waardoor hun productiviteit achterblijft. Een andere verklaring ligt mogelijk in het feit dat tijdelijke medewerkers minder lang bij de apotheek werken, en nog ingewerkt moeten worden. Toch blijkt een langere baanduur van de apothekersassistenten niet samen te hangen met een hogere productiviteit. Apotheken waar assistenten gemiddeld al vele jaren in dienst zijn, hebben zelfs een minder hoge productiviteit. Mogelijk hangt dit samen met het feit dat de laatste jaren veel veranderingen zijn opgetreden in het werk van apothekersassistenten. Zoals uit hoofdstuk 2 blijkt, is het contact met de klant sterk toegenomen. Met name de intensivering van de patiëntenzorg, de toenemende klantgerichtheid, de mondigheid van de cliënten en het afnemend aantal medicijnbereidingen zorgen ervoor dat assistenten steeds vaker ook andere competenties nodig hebben om hun functie goed te kunnen uitoefenen. Apothekersassistenten die al lang in dienst zijn, beschikken mogelijk op deze punten over onvoldoende of enigszins verouderde kennis en vaardigheden en zijn daarom wellicht minder productief.

\section{Schema 5.6}

HRM beleid en de productiviteit in de openbare apotheek, 2001

Minder hoge productiviteit in geval van:

- Assistenten management taken laten uitvoeren

- Apotheken met minder dan 80.000 verwerkte receptregels

- Apotheken met minder dan 9 medewerkers

- Hoger percentage assistenten met een tijdelijke contract

- Langere gemiddelde baanduur van apothekersassistenten

Hoge productiviteit in geval van:

- Om- en bijscholen van apothekersassistenten

- Bieden van een hoger salaris aan nieuwkomers

- Hoger percentage stagiaires

- Apotheken in de regio Middenwest

Bron: ROA/SFK

29. In deze analyse zijn opnieuw de algemene apotheekkenmerken betrokken, met uitzondering van het gemiddelde salaris van de apothekersassistenten in de apotheek. De relatie tussen salaris en productiviteit is namelijk niet eenduidig. Een hoog salaris stimuleert wellicht tot meer productiviteit, maar andersom kan een hoog salaris ook het gevolg zijn van een hoge productiviteit. Om die reden wordt het salaris in de economische literatuur vaak als een maat voor iemands productiviteit gezien. 
Het is dan ook niet verwonderlijk dat het om- en bijscholen van de bij de apotheek werkzame assistenten samengaat met een hogere productiviteit. Als apothekersassistenten, al dan niet door de SBA geaccrediteerde, cursussen volgen, leidt dit echter niet direct tot een hogere productiviteit. Waarschijnlijk is dit een gevolg van het feit dat cursussen deels in werktijd worden gevolgd. Daarnaast zal het waarschijnlijk enige tijd duren voordat het geleerde goed in praktijk gebracht kan worden. Schema 5.6 laat verder zien dat in apotheken waar aan nieuw aangetrokken assistenten een hoger salaris aangeboden wordt de productiviteit hoger is. Mogelijk vergroot het aantrekken van goed betaalde medewerkers de motivatie van het personeel. Ook apotheken met een hoog percentage stagiaires hebben een hogere productiviteit. Dit wijst er op dat deze stagiaires een duidelijke bijdrage leveren aan het te verrichte werk, die opweegt tegen de geïnvesteerde tijd van andere assistenten die aan hun begeleiding besteed moet worden. Ten slotte blijkt dat de apotheken in de regio Middenwest een hogere productiviteit hebben. Hiervoor is niet direct een verklaring aan te wijzen.

\subsection{Enkele concluderende opmerkingen}

Concluderend kunnen we stellen dat apotheken die hun assistenten flexibele werktijden bieden, bijvoorbeeld door veel uren per dag open te zijn, minder knelpunten in de personeelsvoorziening kennen. Apothekersassistenten werken immers het liefst in deeltijd om werk en zorgtaken te kunnen combineren. Apothekers die hun assistenten hierin tegemoet komen zijn aantrekkelijke werkgevers, gezien het lage aantal vacatures dat zij hebben openstaan, de korte termijn waarop deze vacatures vervuld worden en het lagere personeelsverloop. Duidelijk negatiever werkt het invoeren van een prestatiebeloning voor apothekersassistenten. Apotheken die aan prestatiebeloning doen, hebben een hogere vacaturegraad en meer ziekteverzuim. Ook het door assistenten laten uitvoeren van taken uit lagere functies blijkt samen te gaan met een hogere vacaturegraad, een hogere uitstroom en een hogere werkdruk onder de apothekersassistenten.

De analyses in dit hoofdstuk laten zien dat het HRM beleid dat apothekers op dit moment inzetten om de knelpunten in hun personeelsbeleid te verminderen slechts in geringe mate effectief is. Met name het human resource development beleid en het arbeidsvoorwaardenbeleid in de openbare apotheek werpen nog relatief weinig vruchten af. Voor zover het gaat om recent ingezet beleid, of beleid dat juist wordt gevoerd vanwege de knelpunten in de personeelsvoorziening, zal het enige tijd kosten voordat de effecten van dit beleid zichtbaar worden. Met name de effecten van de maatregelen die apothekers treffen om moeilijk vervulbare vacatures aan te pakken, zoals het aantrekken van anders opgeleiden (apotheekhulpen), het verlagen van de opleidings- en ervaringseisen en het inschakelen van het arbeidsbureau, zullen in de toekomst onderzocht moeten worden. 